\title{
European financial market integration: evidence on the emergence of a single Eurozone retail banking market
}

Citation for published version (APA):

Kleimeier, S., \& Sander, H. (2002). European financial market integration: evidence on the emergence of a single Eurozone retail banking market. METEOR, Maastricht University School of Business and Economics. METEOR Research Memorandum No. 060 https://doi.org/10.26481/umamet.2002060

Document status and date:

Published: 01/01/2002

DOI:

10.26481/umamet.2002060

Document Version:

Publisher's PDF, also known as Version of record

\section{Please check the document version of this publication:}

- A submitted manuscript is the version of the article upon submission and before peer-review. There can be important differences between the submitted version and the official published version of record.

People interested in the research are advised to contact the author for the final version of the publication, or visit the DOI to the publisher's website.

- The final author version and the galley proof are versions of the publication after peer review.

- The final published version features the final layout of the paper including the volume, issue and page numbers.

Link to publication

\footnotetext{
General rights rights.

- You may freely distribute the URL identifying the publication in the public portal. please follow below link for the End User Agreement:

www.umlib.nl/taverne-license

Take down policy

If you believe that this document breaches copyright please contact us at:

repository@maastrichtuniversity.nl

providing details and we will investigate your claim.
}

Copyright and moral rights for the publications made accessible in the public portal are retained by the authors and/or other copyright owners and it is a condition of accessing publications that users recognise and abide by the legal requirements associated with these

- Users may download and print one copy of any publication from the public portal for the purpose of private study or research.

- You may not further distribute the material or use it for any profit-making activity or commercial gain

If the publication is distributed under the terms of Article $25 \mathrm{fa}$ of the Dutch Copyright Act, indicated by the "Taverne" license above, 
Version: August 30, 2002

\title{
European Financial Market Integration:
}

\author{
Evidence on the Emergence of a Single Eurozone Retail Banking Market
}

\begin{abstract}
This study provides new evidence on the emergence of a single Eurozone retail banking market. Applying cointegration methodology, the empirical results indicate only limited evidence for integration before January 1 , 1999. The introduction of the Euro manifests itself in structural breaks after which evidence for an emerging uniform Eurozone banking market is increasing. After investigating the interest pass-through we conclude that the single currency has the potential to "complete" the single market, however, not so much in the sense of cross-border arbitrage, but by means of a smooth and uniform pass-through process in the presence of a single monetary policy.
\end{abstract}

JEL classification: E43, E58, F36, G15, G21

Keywords: Financial markets, European monetary integration, Interest rates, Retail banking, Cointegration

by

Stefanie Kleimeier (corresponding author) Universiteit Maastricht - LIFE

P.O. Box 616

6200 MD Maastricht

The Netherlands

e-mail: s.kleimeier@berfin.unimaas.nl

phone: +31-43-3883733

fax: +31-43-3884875

Harald Sander

University of Applied Sciences Cologne

Claudiusstrasse 1

50678 Cologne

Germany

e-mail: gh.sander@t-online.de

phone: +49-221-82753419

fax: +49-221-82753131 


\section{INTRODUCTION}

In 1988 the Commission of the European Communities commissioned a study, now widely known as the Cecchini report (Commission of the European Communities, 1988), which derived quantitative estimates of the benefits of financial market integration. The study predicted that postintegration prices will fall to a level equal to the prices of the country with the lowest pre-integration prices. In order to realize these predicted benefits, the Second Banking Directive $\left(2^{\text {nd }} B D\right)$ was implemented on January 1, 1993 for the member countries of the European Union (EU) with the intent to provide an appropriate regulatory environment for the single European banking market. However, as Kleimeier and Sander (2000) have shown, the degree of integration in the retail banking market before the introduction of the single currency January 1, 1999 was limited, leading to the question to what extent the single currency will contribute to the creation of a single retail banking market. For example, Tommaso Padoa-Schioppa (2000) from the European Central Bank (ECB) board argues that the "multiplicity of currencies in the single market was a fundamental factor behind the preservation of the segmentation of the banking industry" and that "it is indeed the existence of a single currency and a single central bank which very often unifies a banking system". Nonetheless, while most observers find at least some evidence for the emergence of a single banking industry in the area of wholesale banking and capital market activities, they remain more skeptical in the area of retail banking (Padoa-Schioppa 2000, Diez Guardia 2000).

The aim of our study is to provide further evidence on the emergence of a single Eurozone retail banking market. To do so, we develop a methodology that allows us to shed light onto the following: How effective has the single-market cum Second Banking Directive undertaking been so far in integrating credit markets? Are nominal and real cost of borrowing converging across 
Europe and is convergence really a sign of integration? Is there evidence for differential effects in various credit products? How effective is the transmission of interest rate changes by monetary policy onto lending rates and are there differences in the "pass-through" among the countries of the Eurozone and among the various lending rates? What has so far been the contribution of the single currency and what is its likely future impact on this process?

The attempt to answer these questions today is ambitious for the very simple reason that the data available by now is still limited. However bearing in mind the Lucas critic, drawing conclusions from past data after almost revolutionary changes in the European monetary system might be even more risky than relying on an almost three-year experience with a single currency. Nonetheless, we fully bear in mind the limitations of the analysis resulting from the brief sample period but hope to develop an approach that allows us to answer these research questions in principal and with increasing confidence as the integration process unfolds. In particular, as this study follows up on an earlier consultancy report (Kleimeier and Sander, 2002) we find that using now an extended database our earlier results and conclusions are by and large validated thus pointing to the robustness of the approach.

\section{TOWARDS AN INTEGRATED EUROPEAN RETAIL BANKING MARKET?}

\subsection{Recent developments in European banking}

Bank lending plays a dominant role in providing funds to the corporate, private, and public sector in Europe. Based on data for 1999 provided by the European Central Bank (ECB) (2000a), in the Eurozone bank loans amounted to 100.4 per cent of the gross domestic product (GDP) which is clearly higher than for example 48.4 per cent in the United States (US). In contrast, 
market based forms of funding which are an alternative for corporations are used to a lesser extend in the Eurozone. Outstanding domestic debt securities amount to 88.8 per cent in the Eurozone compared to 164.6 per cent in the US and stock market capitalization amounts to 71.1 per cent in the Eurozone compared to 163.3 per cent in the US.

The banking market in the European Union (EU) has been shaped to a large extend by the regulatory process aiming at liberalization and integration. At the beginning of the 1980s, the banking markets of Italy, France, and Belgium could be considered to be highly regulated, whereas banking markets in Germany, the United Kingdom (UK), and the Netherlands were only slightly regulated (De Bondt 1998). For example, capital controls were in place in many highly regulated countries. Furthermore, interest rate regulations existed as late as 1992 or 1993 in some EU member countries (Diez Guardia 2000). Specifically, interest rates were deregulated early in the UK (1979), Germany (1981) and the Netherlands (1981) compared to Denmark (1988), Belgium, France, Italy, and Luxembourg (all 1990), Spain and Portugal (both 1992), Ireland and Greece (both 1993). Even if the establishment of the common market has been an objective in the EU since the 1957 Treaty of Rome and has been reinforced by the 1985 White Paper and the 1986 Single European Act, very little had been achieved for the banking markets until the $2^{\text {nd }}$ BD of 1989. Regarding key regulatory elements, the First Banking Directive ( $1^{\text {st }}$ BD) of 1977 which allowed for cross border branching under the host country rule ${ }^{1}$ was not very effective in reducing differences between national regulatory systems and was thus followed by a $2^{\text {nd }}$ BD. This $2^{\text {nd }} \mathrm{BD}$ relied on three fundamental principles of harmonization, mutual recognition, and

\footnotetext{
${ }^{1}$ Under the host country rule a bank had to obtain permission to operate in a foreign country by the supervisory agencies of that country.
} 
home country control and supervision ${ }^{2}$ - the latter representing a complete turnaround in regulatory policy compared to the $1^{\text {st }}$ BD. Since 1986 , additional directives which are aimed at further harmonization of the different national EU banking markets have been passed concerning bank supervision, capital adequacy, solvency standards, money laundering, consumer credit, or publishing and consolidation of annual accounts to name but a few ${ }^{3}$. In the area of consumer credit, in 1986 the European Community introduced a consumer credit directive. The main two objectives of this directive were consumer protection and facilitation of cross-border credit by means of harmonization of the banks' information provision to its customers. This directive was amended and completed by two more consumer credit directives in 1990 and 1998, respectively ${ }^{4}$. In 1999, the Financial Services Action Plan (FSAP) has been launched which is widely considered the principal blueprint for financial integration in the EU by means of 42 measures to foster the progress towards an integrated market. By spring 2002, 26 of these 42 measures have been finalized, but the remaining measures are still considered to be crucial. Thus, the Barcelona European Council in March 2002 has called for a full implementation of all measures by 2005. On January 1, 1999, the Euro replaced the national currencies of Austria, Belgium, Finland, France, Germany, Ireland, Italy, Luxembourg, the Netherlands, Portugal, and Spain. Of the remaining EU countries, Greece initially failed to meet the required economic criteria but joined the European Monetary Union (EMU) on January 1, 2001, whereas Denmark, Sweden, and the United Kingdom decided not join the EMU as yet.

\footnotetext{
${ }^{2}$ Harmonisation should lead to a system where banks operating in several countries face a common set of EU regulations. Mutual recognition implies that the banking charter of the home country is sufficient to operate in all EU countries. Home country rule, finally, stipulates that foreign owned banks are regulated by their home country and not by the host country.

${ }^{3}$ For details see Kleimeier (2001), Kleimeier and Sander (2000), Diez Guardia (2000), Zimmerman (1995).

${ }^{4}$ For details and evaluation see Diez Guardia (2000).
} 
Assessing the Eurozone banking markets, integration can be considered as far advanced from a purely legal perspective (Zimmerman 1995, Bredemeier 1995). However, non-regulatory barriers to integration such as cultural differences in consumer behaviors such as preferences for types of credit continue to exist. Whereas Eurozone interbank and wholesale markets are considered to be integrated, the extent of integration in the retail banking markets appears to be limited. For one thing, retail lending products are less exposed to international competitive pressure as proximity to customers is important even when one accounts for advances in modern distribution technology. Furthermore, this impression is enforced when looking at the limited extent of cross-border lending. The focus in bank lending and deposit taking is clearly domestic. In 1999, 79.8 per cent of all loans and 72.8 per cent of loans to the non-bank private sector were domestic. Similarly, 72.8 per cent of all deposits and 86.5 per cent of deposits to the non-bank private sector were domestic. Moreover, 66.7 per cent of all government securities and 39.5 per cent of all non-bank private securities are domestic. Only for this last business activity is the foreign business dominant and Euro area holdings amount to 19.1 per cent. However, the growth rates for all Eurozone activities - with the exception of deposits from the non-bank private sector - are positive and larger than the corresponding growth rates for domestic activities. Furthermore, the market shares of foreign banks in Europe are still very low in most countries in 1997. In Denmark, France, Italy, the Netherlands, Austria, Finland, Portugal, and Spain foreign banks have a market share of less than 12 per cent. In Belgium and Ireland, their market shares lie in the mid-range with 36.3 and 53.6 per cent, respectively. Only in Luxembourg foreign banks dominate the market with a share of 99.9 per cent (ECB 1999a, 1999b, 2000a, 2000b). Similar figures have been reported by Diez Guardia (2000). 
One reason for these localized retail banking markets where banks are neither reaching out for all prospective Eurozone customers, nor are consumers shopping around for credits in the whole Eurozone is given by Padoa-Schioppa (2000). He refers to a survey conducted by the US Federal Reserve Bank that has found that in the United States $90 \%$ of the banks clientele is located within a distance of less than 20 miles of the bank's premises. He concludes that "proximity is an intrinsic characteristic of the retail market with or without the emergence of a currency embracing a wider area". One should, however, read such results with caution, as the localization of retail banking in the USA is also, and in particular the result of the US banking regulation ${ }^{5}$.

Another reason for the lack in cross border lending could lie in the organizational strategies adopted by European banks with respect to type of bank they want to become in an integrated European banking market: In principle, a bank can either become a Europe-wide universal bank, a domestic universal bank, a Europe-wide specialized bank, or a domestic specialized bank. According to Marois (1997), the strategies adopted by European banks are diverse and a predominant strategy has yet to crystallize. However, the EU deregulatory process sparked two phases of bank mergers and acquisitions (M\&As) in Europe: The first phase took place in the late 1980 s and early 1990 s in reaction to the $2^{\text {nd }} \mathrm{BD}$ and the second phase took place in the second half of the 1990s in anticipation of the EMU (Tourani Rad and van Beek, 1999). As Padoa-Schioppa (2000) argues, it is an error to believe that "a single banking industry will only emerge when cross-border mergers occur". However, the pattern of M\&As can give us an indication about the types of banks operating in the European market.

\footnotetext{
${ }^{5}$ Especially, the McFadden Act, which was in place from 1927 until 1994 explicitly prohibited interstate branching. In 1994, the basis for a truly US wide banking system was laid with the adoption of the Riegel-Neal Interstate Banking and Branching Efficiency Act.
} 
From Table 1 note first that the total value of domestic M\&As exceeds that of cross-border M\&As, mainly driven by acquisitions of commercial banks and securities firms. Only for insurance companies the value of cross-border M\&As exceed the value of domestic M\&As. This implies that consolidation is still taking place on a national rather than international level. Furthermore, for commercial banks and securities firms M\&As within Europe are as important as other foreign M\&As, indicating a global rather than regional consolidation process. Second, consolidation within the sector is more common than consolidation across sectors - with domestic M\&As and to a lesser extend Europe-Non-Europe M\&As when the acquirer is a securities firm being the only exceptions. This would indicate that most banks in Europe are still specialized rather than universal banks. Taken together these findings show that the typical EU bank can still be characterized as a specialized domestic bank. Therefore, the result presented earlier that most bank activities are still domestic in nature is not surprising ${ }^{6}$ (Kleimeier 2001).

\section{TABLE 1 ABOUT HERE}

\subsection{What constitutes an integrated banking market?}

\subsubsection{The non-applicability of the "law of one price" in credit markets}

Quantifying the degree of integration of the retail banking market is not an easy task. The Cecchini study advances the hypothesis of price equalization for financial assets within Europe as the characteristic of completely integrated markets. This "law of one price" manifests itself in financial markets as the interest rate parity. It is well established that under perfect capital

\footnotetext{
${ }^{6}$ It is interesting to note that the only strategy which can be characterised as clearly European is the acquisition strategy that insurance company follow within Europe when acquiring banks. This strategy amounts to $13.4 \%$ of all
} 
mobility the covered interest parity typically holds, but it is more difficult to establish the empirical validity of the uncovered interest parity due to exchange rate volatility or exchange rate expectations. In the context of retail banking the case for the law of one price is, however, not so straightforward. First, the interest rate parity is suggested as parity for interest rates on such assets like government bonds, which are close if not perfect substitutes. This is clearly not the case for bank assets like consumer credits. Rather, credits are characterized by heterogeneity caused by risk differences, cultural influences in bank-client relationship, country-specific strategic bank behavior in order to cope with informational imperfections (moral hazard, incentive effects etc.), to name just a few. Consequently, one cannot expect the law of one price to hold in the strict sense in the consumer credit market. Secondly, there is clearly not (yet) a perfect "capital" mobility. As discussed in the previous section, banks are neither reaching out for all prospective Eurozone customers, nor are consumers shopping around for credits in the whole Eurozone, i.e. retail banking is still localized. Thus, retail interest rates may not as easily equalize as suggested by the Cecchini study. Rather, even when they are equalizing but the underlying characteristics of credits are different, this may not even be a sign of an integrated banking market. Looking simply at interest rate convergence or equalization can therefore be profoundly misleading.

\subsubsection{Interest rate trends in the Eurozone - Some descriptive statistics}

Despite the reservation we have about the use of the descriptive statistics we report them in Table A1 in the appendix and illustrate the (non-) convergence process in Figures 1 to 3 . We report the following interest rates as obtained from ECB's National Retail Interest Rates 
Statistics: mortgage loans to households (N2), consumer loans to households (N3), and the lending rate charged to the corporate sector (N4). These rates are available on a monthly basis starting in the 1980s with most countries reporting regularly as off 1989 (a more detailed description of the data is provided in the appendix).

\section{FIGURES 1, 2, 3, ABOUT HERE}

Figure 1 and 2 show the convergence of interest rates for mortgage rates, consumer lending rates and corporate lending rates in both, nominal and real terms. In general, we divide our sample that ranges from April 1995 to April 2002 into a pre-EMU period until December 1998 and an EMU period thereafter. Clearly, all nominal rates are now closer together then they were in the mid1990s. But this can largely be attributed to the effect of macroeconomic factors, in particular the single monetary policy. It is also clear that mortgage rates are closer together because the credit characteristics across countries are more similar throughout the Eurozone as compared to the lending rates charged for the other credit forms that differ more widely in their characteristics (as well as in their statistical definition). For example, while Italy had the highest average mortgage rate of 11.1 per cent in the pre-EMU phase and Belgium with 6.1 per cent the lowest rate, both countries have in the EMU phase the almost identical average rate of about 6 per cent. However, as argued before, interest rates need not equalize - and in most cases should not equalize even in the presence of an integrated banking market. From the "localized" borrower's point of view, however, the real, consumer price inflation-corrected costs of mortgage borrowing still differ widely throughout the Eurozone after January 1999, with the highest real cost in France (5.0 per 
cent) and the lowest in Ireland (1.2 per cent), mainly because of differences in consumer price inflation. As far as consumer and corporate lending rates are concerned, also here the crosscountry differences have become smaller, but they still remain large.

In Figure 3 we show the development of the spreads between retail lending rates and the money market rate (as a proxy of the banks' cost of funding), which could be interpreted as a rough proxy for credit market imperfections. A recent study by Corvoisier and Gropp (2001) has shown that despite the pro-competitive move in European banking through deregulation, the increased concentration stemming from the recent wave of bank mergers may have resulted in less competitive loan pricing by banks. Our figure is consistent with this assessment and additionally shows that spreads differ significantly across countries but also across lending markets with spreads for consumer lending typically being the highest. Moreover, as far as convergence patterns are concerned, the only clear effect can be found in the mortgage market.

\subsubsection{Cointegrated retail banking markets}

Because of the different characteristics of the various (still) national credit instruments (as well as the differences in the reported statistics), we propose to base the judgment about the existence of a uniform Eurozone retail banking system on the existence of cointegration among national credit markets in Europe. This concept realizes that although full equalization cannot be expected, the concept of market integration requires that interest rates should exhibit a certain long-run equilibrium relationship. Thus, we do not require that the national interest rate of a country $\left(\mathrm{L}_{\text {nat }}\right)$ should equal the interest rate in the remaining Eurozone $\left(\mathrm{L}_{\mathrm{EU}}\right)$ as it would be required by the law of one price shown in equation (1): 
Rather, we accept as a possible long run relationship that the rates may differ from each other such that:

$$
\text { (2) } \quad \mathrm{L}_{\mathrm{nat}}=\mathrm{a}+\mathrm{b} \mathrm{L}_{\mathrm{EU}}
$$

In the long-run, equation (2) can be interpreted as a relationship reflecting the existence of a financial system with "structural trends and systematic disturbances in banking [that] cut across state borders" "7 while in the short-run deviations from the long-run equilibrium relationship are possible. This equation could in principle be estimated by means of regression analysis. However, since interest rates typically follow a random walk one may obtain spurious results from regression analysis. To establish that there exists a certain long-term relationship one therefore has to undertake a cointegration analysis. If cointegration is found, this reflects that national interest rates are connected in terms of a long-term relationship as shown in equation (2). This retail interest rate link must, however, not necessarily reflect banking market integration in the sense of arbitrage as suggested by Cecchini. Rather, in the short-run deviations from this long-run equilibrium can be corrected over time by one or more of the following three mechanisms:

- An international arbitrage (cross-border lending) process where banks increasingly shift their lending activities to countries where lending rates are the highest while consumers borrow in low interest rate countries.

\footnotetext{
${ }^{7}$ For this sentence we have used the words of Padoa-Schioppa (2000) with which he refers to the localized US financial system that is commonly viewed as integrated.
} 
- When money market rates equalize by means of an international arbitrage process such changes will have an impact on lending rates via domestic competition that ties lending and borrowing rates together (interest rate pass-through).

- Increased (international) competition, or the threat of it as suggested by the theory of contestable markets will help to harmonies the pricing behavior of banks and thus lead to a harmonization of retail prices.

In the context of our study, we apply cointegration methodology closely based on the approach promoted by Engle and Granger (1987), which proceeds in three steps. First the time series must proven to be unit roots. Only then the cointegration vector can be estimated. Finally, once cointegration has been established, the corresponding error correction model will be estimated.

In order to establish whether the interest rates are unit roots, or I(1), two test statistics, a tstatistic and an F-statistic, will be employed based on regressions on levels as well as first differences of the underlying series. Both include next to lagged observations of the lending rate $\mathrm{L}$ in question also a trend variable $\mathrm{T}$ :

$$
\begin{aligned}
& \text { (3.1) } \Delta \mathrm{L}_{\mathrm{t}}=\eta_{0}+\eta_{1} \mathrm{~L}_{\mathrm{t}-1}+\eta_{2} \Delta \mathrm{L}_{\mathrm{t}-1}+\eta_{3} \mathrm{~T}+\varepsilon_{\mathrm{t}} \\
& \text { (3.2) } \Delta^{2} \mathrm{~L}_{\mathrm{t}}=\eta_{0}+\eta_{1} \Delta \mathrm{L}_{\mathrm{t}-1}+\eta_{2} \Delta^{2} \mathrm{~L}_{\mathrm{t}-1}+\eta_{3} \mathrm{~T}+\varepsilon_{\mathrm{t}}
\end{aligned}
$$

The null hypothesis states that the series follow random walks. For the t-statistic, this corresponds to a null hypothesis of $\mathrm{H}_{0}: \eta_{1}=0$ and for the F-statistic to a null hypothesis of $\mathrm{H}_{0}$ : $\eta_{1}=\eta_{3}=0$. We fail to reject the null hypothesis of a random walk if the calculated $t$ or $F$ values 
are smaller in absolute terms than the critical values. Thus, as a precondition for cointegration, we have to accept the null hypotheses for equation (3.1.) but reject them for equation (3.2). As shown in Table A2 in the appendix the pre-condition that the time series are integrated of the order 1 is generally fulfilled. For nominal and real lending rates, there is evidence for I(0) or I(2) for only $10 \%$ of the series.

Once the I(1) characteristic has been established, cointegration testing can commence starting with estimating the cointegration regression using the national lending rate $\mathrm{L}_{\text {nat }}$ for the individual country as the dependent variable and the weighted average rate for the remaining EU countries $\mathrm{L}_{\mathrm{EU}}$ as the independent variable:

$$
\text { (4) } \quad L_{n a t, t}=a+b L_{E U, t}+u_{t}
$$

A first cointegration testing procedure relies on the Durbin-Watson statistics (DW). The null hypothesis of no cointegration can be rejected when the calculated DW values resulting from the regression of equation (4) are larger than the critical values. As Engle and Granger point out, the Durbin-Watson test can be used as a good but only approximate indicator for cointegration and should be followed by a more specific testing procedure such as the Dickey-Fuller (DF) and augmented Dickey-Fuller (ADF) tests. The Dickey-Fuller test is based on the residuals of the cointegration regression

$$
\text { (5) } \Delta \hat{\mathrm{u}}_{\mathrm{t}}=-\delta_{0} \hat{\mathrm{u}}_{\mathrm{t}-1}+\varepsilon_{\mathrm{t}}
$$


where the t-statistic for the estimated coefficient $-\delta_{0}$ provides an indication regarding the cointegration of the two series. In particular, the null hypothesis of no cointegration can be rejected when the t-statistic is larger in absolute value than the critical value.

The augmented Dickey-Fuller test is obtained in a two-step procedure from the regression

$$
\Delta \hat{\mathrm{u}}_{\mathrm{t}}=-\delta_{0} \hat{\mathrm{u}}_{\mathrm{t}-1}+\sum_{i=1}^{4} \delta_{\mathrm{\imath}} \Delta \hat{\mathrm{u}}_{\mathrm{t}-\mathrm{i}}+\varepsilon_{\mathrm{t}}
$$

In the first step equation (6) is estimated including all 4 lags of $\Delta$ ût-i. In the second step, equation (6) is re-estimated including only the significant lags of $\Delta$ ût-i from step 1 . Now, the null hypothesis of no cointegration can be rejected when the t-statistic for the estimated coefficient $-\delta_{0}$ is larger in absolute value than the critical value.

Once the existence of a long-run relationship, i.e. cointegration is established, one can investigate the short-run dynamics of interest rates by estimating the corresponding error correction model (ECM). This model will provide an estimate of the speed of adjustment, with which the system returns back to the long-run equilibrium. To find the correct specification of the ECM, first, an unrestricted vector autoregression (UVAR) is estimated based on the regression

$$
\Delta \mathrm{L}_{\text {nat, },}=\lambda_{0}+\lambda_{1} \mathrm{~L}_{\text {nat, } \mathrm{t}-\mathrm{1}}+\lambda_{2} \mathrm{~L}_{\mathrm{EU}, \mathrm{t}-\mathrm{1}}+\sum_{i=1}^{4} \lambda_{\text {nati }} \Delta \mathrm{L}_{\mathrm{nat}, \mathrm{t}-\mathrm{i}}+\sum_{i=1}^{4} \lambda_{\mathrm{EUi}} \Delta \mathrm{L}_{\mathrm{EU}, \mathrm{t}-\mathrm{i}}+\varepsilon_{\mathrm{t}}
$$


From this regression, the significant lagged first differences of the exogenous and endogenous variables are identified and included in the final ECM in combination with any error correction terms $(\mathrm{ECT})$ obtained from the estimated errors $\hat{\mathrm{u}}_{\mathrm{t}-1}$ of the cointegration regression

$$
\Delta \mathrm{L}_{\mathrm{nat}, \mathrm{t}}=\varphi_{0}+\varphi_{1} \hat{\mathrm{u}}_{\mathrm{t}-1}+\sum_{i=1}^{4} \varphi_{\text {nati }} \Delta \mathrm{L}_{\mathrm{nat}, \mathrm{t}-\mathrm{i}}+\sum_{i=1}^{4} \varphi_{\mathrm{EUi}} \Delta \mathrm{L}_{\mathrm{EU}, \mathrm{t}-\mathrm{i}}+\varepsilon_{\mathrm{t}}
$$

The estimated coefficient $\varphi_{1}$ of the ECT measures the speed of adjustment. For example, an estimated $\varphi_{1}$ of -0.2 indicates that if there is a shock to the national lending rate $\mathrm{L}_{\mathrm{nat}, \mathrm{t}}$, which raises its value relative to the equilibrium relationship to the cointegrated EU-wide lending rate $\mathrm{L}_{\mathrm{EU}, t}$, then one fifth of the divergence is eliminated in the following period.

In the remainder of the study, we will investigate the presence or non-presence of such a longterm relationship among Eurozone retail banking markets and inquire into the mechanisms that eventually bind national interest rates together. However, given the countries and time periods, which are the focus of our study, it is very well possible that the introduction of the single currency has brought about structural changes in the cointegration relationship. In order to detect whether any such structural changes are present and if so, at what time they occur, we conduct a structural break analysis of the cointegration regression. In particular, we estimate a rolling Chow test, which implies the following procedure: First, the cointegration regression of equation (4) is estimated for the full sample ranging from April 1995 to April 2002. However, in the presence of a structural break, the DW, DF, and ADF cointegration tests have low power, i.e. the rejection frequency of the ADF test is clearly reduced (e.g. Gregory et.al., 1996). Thus, in a 
second step, the cointegration vector is tested for structural breaks such that $\mathrm{H}_{0}: \mathrm{at}_{\mathrm{t} 1}=\mathrm{a}_{\mathrm{t} 2}$ and $\mathrm{b}_{\mathrm{t} 1}$ $=b_{t 2}$ with sub-samples $t 1=1$ to $k$ and $t 2=k+1$ to $\mathrm{T}$. If $\mathrm{k}$, the time of the break is known, the two samples $\mathrm{t} 1$ and $\mathrm{t} 2$ are clearly identified and a standard Chow test can be conducted. In our case, we consider a break to be likely around January 1999, but the exact timing of the break -if indeed there is any- is not known. Thus, rather than using a standard Chow test, a supremum F (supF) test is calculated. This test was first proposed by Quandt (1960) and has more recently been the focus of various studies (e.g. Andrews 1993, Diebold and Chen 1996, Hansen 1992). In our single equation model, the supF test can be found by conducting a series of Chow tests. In particular, Chow tests are conducted for a series of different break points k, which move through the mid-80\% of the sample. SupF equals the largest Chow F-statistic and is compared to critical values as reported by Hansen (1992). Depending on the model, the number of observations, etc, any estimated supF test statistic larger than approximately 15 will allow us to reject the null hypothesis of no structural break. Furthermore, the sequence of F-statistics can give an indication about the timing of the break.

Table 2 reports the test statistics and the timing of our structural break test that we have been conducting for the cointegration relationship for both nominal and real lending rates. ${ }^{8}$ The first striking result is that for nominal interest rates almost all long-run relationships show evidence in favor of a structural break around the time of the introduction of the single currency. This evidence seems to be in line with the view that a single currency had a major impact on the unification of a banking system. For real interest rates we often find structural breaks occurring earlier. This may be interpreted as the result of the convergence process in terms of inflation 
rates that happened in the mid $1990 s^{9}$. Consequently, we generally divide the sample into a preEMU sub-period and an EMU sub-period. As can be seen the pre-EMU period is not always free of structural breaks but for the sake of comparability we have chosen the 1995 to 1998 period. For the EMU period, we estimate the cointegration vector over both, the whole EMU period and over a shorter post-break period when appropriate.

\section{TABLE 2 ABOUT HERE}

\section{IS A UNIFIED EUROPEAN RETAIL BANKING MARKET EMERGING? NO, (MAYBE) NO, AND}

\section{MAYBE (YeS)!}

Our judgment on the emergence of a uniform European banking system will in the following be based on the result of the proposed cointegration analysis that we performed for all retail lending rates for the Eurozone countries in both, nominal and real terms. While we are confident that the methodology we propose is helpful in monitoring the progress towards an integrated European banking market, the existing database is still the major obstacle for making to strict judgments at the moment, for three reasons: First, there is no sufficiently harmonized data on credit and in particular consumer credit (Diez Guardia 2000). This problem can and should be addressed in the future, but in the meantime the data provided by the ECB can be used as a first proxy. Secondly, the time period for which data for all countries are available simultaneously is very

\footnotetext{
${ }^{8}$ Figure A1 and A2 in the appendix visualize the results. Typically the peaks in the figures represent the presence and timing of the structural break, provided the F-statistics value exceeds the critical value.

${ }^{9}$ To illustrate this point consider fully integrated real interest rates with the real interest rates in two countries both being 5 percent (and thereafter varying driven by the same structural trends). With an expected inflation rate of 2 percent in both countries, the nominal rate would be 7 percent. Now consider one country starting from an inflation rate expectation of 6 percent, which would imply a nominal interest rate of 11 percent. If now inflation and subsequently inflation expectations would converge to 2 percent, the nominal interest rate in the high-inflation
} 
limited. And third, the introduction of the single currency has brought about structural changes that limit the available database further. In particular, we find that the introduction of the single currency in 1999 has sufficiently shaken up the structural relationship to base judgment on the current state of integration only on data relating to the EMU phase. This reduces the database from which to derive judgments to three and a half years, which obviously limits the power of the statistical work. The only way to avoid this reduction would be to include past data that may not reflect to current state of integration. Given the data limitation, the results of the study will have to be interpreted with caution, but are, however, in our view still very valuable. An earlier study conducted by the authors (Kleimeier and Sander 2002) using a two years estimation horizon is thus extended here. As we will show, most of our earlier results are remaining valid, thus suggesting a certain robustness of the estimates. Where important differences between the current and the earlier estimates appear we will comment on them explicitly.

Figure 4 illustrates the results of the cointegration analysis for nominal interest rates, Figure 5 for real interest rates. The figures are summarizing the empirical testing for which the details are made available in Table 3 and A3 in the appendix. Only for countries and sample or sub-sample periods where bars are shown, a cointegration relationship could be established. The absence of a bar therefore indicates that we do not find any evidence of cointegration of these countries' lending markets with the corresponding Eurozone lending market (countries for which data are not available are clearly indicated with an N.A.). The height of the bars then simply indicates how fast the national rates are returning to the long-term equilibrium. It should be noted, however, that in some cases despite the fact that cointegration has been accepted in the test 
procedures the error-correction mechanism was not found to be statistically significant at an at least 10 per cent confidence level. In such cases striped bars are being used. Moreover, for the EMU period in a number of countries structural breaks occur after January 1999 - in some cases as late as June 2001, thus limiting the reliability of the estimates. Whenever we report the results for a post-break EMU period, the break point is indicated above the bar as a reminder to the above-mentioned limitations. Do we then find evidence for a uniform European retail banking market? The brief answers are: No for mortgages, maybe no for consumer lending, and maybe yes for corporate lending. Or to go into more detail:

1. As argued earlier, judgments about market integration based on interest rate convergence can be misleading. For example, nominal European mortgage rates are converging because they are by and large following the money market rate developments. But as shown in our results here they do not (yet) exhibit a long-term equilibrium relationship in many cases.

2. Regarding nominal mortgage lending rates, we find only very limited evidence in favor of cointegration. The only EMU-member country that exhibits cointegration over the whole estimation horizon is France ${ }^{10}$ whereas for Belgium cointegration is only present in a postbreak period starting in May 1999. The latter result emerged only when using the extended sample until April 2002. For Germany and the Netherlands cointegration is only present in the pre-EMU period and - surprisingly - not in the EMU period. Interestingly, for non-EMU countries Sweden ${ }^{11}$ and the UK cointegration can be found. Again, particularly the postbreak period for these countries suffers from a very short estimation horizon so that the results should be interpreted with care.

\footnotetext{
convergence process.

${ }^{10}$ Recall, however, that French data were only available with a quarterly frequency thus limiting the reliability of this result.
} 
3. While there is very little to almost no evidence for cointegration in mortgage markets in nominal terms, there is somewhat more evidence for cointegration for nominal consumer rates. For the EMU-members France, Germany, Greece, Portugal, and Spain we find a statistically significant adjustment process towards a long-term equilibrium relationship, which is generally stronger or just only becoming statistically significant in the EMU-period and in particular in the shorter post-break periods. A similar observation holds true for the non-EMU member Sweden and UK, possibly suggesting that the observed tendencies reflect probably the impact of the generally declining level of interest rates over the sample period which may or may be not followed smoothly by consumer lending rates. This suggests that the pass-through mechanism in the various countries may play an important role in producing these statistical artifacts. While we find that our earlier conclusion of "no" evidence for cointegration in consumer lending must be slightly modified into a weaker "maybe no", the fact that with the exemption of Portugal and Spain the error correction mechanism exhibits only a slow speed of adjustment which points to still weakly linked lending markets. Nevertheless, the introduction of the single currency may already show its first effect here.

4. For the corporate sector the evidence is pointing to a number of cases where nominal cointegration could be established in particular in the EMU phase. It can also be observed that the ECT-coefficients are often higher than in the other markets, eventually pointing to the more important role of competition (direct vs. indirect finance etc.) in this sector. It is interesting to note that in particular those EMU countries who have often been dubbed as "non-core EMU" such as Ireland, Italy, Portugal, and Spain may have been most effected by integration efforts as we find here a significant and high speed of adjustment toward the

\footnotetext{
${ }^{11}$ Note that for Sweden also only quarterly data are available.
} 
long-run equilibrium relationship in the EMU period. However, it is also striking that for core-EMU countries such as Austria, Belgium, Germany and the Netherlands we were not (anymore) able to detect evidence for cointegration in the EMU period. Again, the particularities of the pass-through process in the latter four countries could be potential suspects for explaining this result, such as a close bank-firm relationship, which eventually limits the flexibility of lending rates.

5. In real (inflation-corrected) terms there is some more evidence in favor of cointegration in mortgage rates despite the fact that real mortgage rate diverge more than nominal ones. For the first two years of the EMU our earlier study has found cointegration for Austria, Finland, Germany, Netherlands, Portugal, and in Spain. This already more pronounced trend towards cointegration in the EMU is reinforced in the extended sample (also by using an explicit post-break period), with Austria and the Netherlands exhibiting now a more forceful errorcorrection mechanism, while cointegration and a significant ECT could be found now for Belgium, France, Greece, and Italy. Note however, that some EMU members are either not exhibiting an ECM anymore (Finland, Germany, Portugal) or that the ECT is showing lower values (Spain). Given the role of inflation expectations for the determination for real mortgage rates, the evidence for or against cointegration of real mortgage rates may thus reflect the convergence or non-convergence of inflation expectations in the Eurozone. From the point of view of the individual borrower the almost non-existence of nominal cointegration suggests unexploited arbitrage possibilities and as such a lack of integration.

6. For real consumer lending rates, however, we have found in our earlier study that evidence for cointegration was less pronounced than for real mortgage rates. The mortgage rate results may have reflected the fact that borrowers extensively compare prices nationally, that the 
national markets are more competitive and that inflation expectations play an important role in the long-term oriented mortgage market. In consumer lending, the sketchier evidence for cointegration may have pointed to a less competitive environment often characterized by high switching costs. However, after extending the sample period, the evidence for cointegration has improved, suggesting the potentially unifying role of a common monetary policy. Note, however, that a statistically significant structural break occurred for a number of countries relatively late after the introduction of the single currency thus limiting the reliability of this finding.

7. The strongest results for cointegration in real borrowing costs can be found for corporate rates. For 10 out of 12 countries we find a significant error correction mechanism for the EMU period.

In sum, we find (almost) no evidence for a uniform banking market for mortgages. The picture differs, however, if one turns from nominal to real lending rates. Here mortgage rates appear to be more cointegrated, i.e. households' real cost of mortgage borrowing are more likely to follow similar structural trends in the Eurozone. The evidence for cointegration in consumer credits is only somewhat better, again slightly more so for real than for nominal rates. Our conclusion is therefore also a "maybe no". But we do find quite some evidence for more unified corporate lending in the EMU phase from nominal as well as real rate analysis. A "maybe yes" might therefore be justified, in particular in the EMU phase. Our "no, (maybe) no, and maybe (yes)" conclusion is, however, subject to three reservations. First, and as mentioned before, our sample size is for obvious reasons quite short for the EMU period thus limiting the validity of conclusions. It is, however, reassuring, that our result presented here, are very much validating 
the results of our earlier study. Second, by extending the sample we are also able to confirm our earlier observation that as the effects of the single currency unfold, the so far rather sketchy evidence for integration increases. Finally and most importantly, equating evidence in favor of cointegration with integrated markets can be misleading. Cointegration in banking may not be brought about by cross-border lending, mergers and acquisitions, or international arbitrage. Rather, the statistical evidence of cointegration under the condition of a single monetary policy may simply reflect a smooth and homogeneous pass-through of monetary policy rate changes onto lending rates in all EMU member. The latter phenomenon will be investigated in the following section.

\section{TABLE 3 AND FIGURE 4 AND 5 ABOUT HERE}

\section{PASS-Through OF INTEREST RATES Changes TO LENDing RATES: A Still SEgmented Eurozone BANKIng MARKet?}

Evidence for cointegration in lending markets can be produced by three mechanisms: arbitrage, (threat of) international competition, and a uniform monetary policy impact on lending rates. Based on the few cases in which we found cointegration one cannot directly identify that arbitrage and competition are the driving mechanisms. In this case, retail interest rates could in principle follow the same time pattern if banks in the different Eurozone countries would pass changes in policy-related interest rates smoothly and with the same speed onto lending rates. On the other hand, the cases in which we did not find cointegration indicate not only a lack of arbitrage and international competition but also an ineffective and/or heterogeneous monetary policy impact on lending rates. An ineffective pass-through of interest rates could be interpreted 
as pointing to a high degree of imperfect competition in retail banking (Cottarelli and Kourelis, 1994). A heterogeneous pass-through could be interpreted as limited institutional convergence in Eurozone banking (Kleimeier and Sander 2000, Sander and Kleimeier 2002). Thus, the investigation of the limitations and differences in the pass-through of interest rates in the Eurozone can provide indirect evidence about forces driving or limiting the emergence of a unified Eurozone retail banking market.

\subsection{Pass-Through Methodology}

Following Cottarelli and Kourelis (1994), a growing literature is discussing the response of lending rates to monetary policy impulses as an important part of the monetary transmission process. These approaches typically model the transmission process in a dynamic model for the lending rate such as

$$
L_{t}=\beta_{1}+\beta_{L} L_{t-1}+\beta_{M} M_{t}+\varepsilon_{t}
$$

where $\mathrm{L}_{t}$ and $\mathrm{M}_{\mathrm{t}}$ are the national lending and money market rates, respectively (where we omit the subscript 'nat' because only national lending rates are part of the pass-through analysis and a distinction between national and EU-wide lending rates is not required in this context). The estimated coefficient $B_{M}$ is the impact multiplier. A value of less than 1 indicates sluggish adjustment of lending rates to money market rates, also known as lending rate stickiness ${ }^{12}$. This leads to a partial adjustment process over time towards a long-run equilibrium. In the long run

\footnotetext{
${ }^{12}$ The study by Corvoisier and Gropp (2001) confirms that increases in concentration in the Eurozone banking sector can make the transmission of monetary policy to lending rates more sluggish.
} 
when the lending rate reaches its steady state value for any given value of the money market rate, i.e. $L_{t-1}$ equals $L_{t}$, equation (9) takes the form of:

$$
L_{t}=\theta_{0}+\theta M_{t}+u_{t}
$$

Cottarelli and Kouralis (1994) argue that this formulation is consistent with the monopolistic competition model relating the lending rate to the money market rate. If $\theta$ is equal to one, we speak of a full pass-through in the long-run, while the parameter $\theta_{0}$ reflects then the mark-up over costs in the pricing policies of the banks.

We estimate a slightly revised version of Cottarelli and Kouralis (1994) given by

$$
L_{t}=\beta_{1}+\sum_{i=1}^{k^{*}} \beta_{L, i} L_{t-i}+\beta_{2} M_{t}+\sum_{i=1}^{n^{*}} \beta_{M, i} M_{t-i}+\varepsilon_{t}
$$

$\mathrm{k}^{*}$ and $\mathrm{n}^{*}$ are defined as the model's optimal lag-length which is determined by the minimum AIC criteria for models with up to 4 lags. Note that for $\mathrm{k}=1$ and $\mathrm{n}=0$ this model is equivalent to the model of equation (9). Similar to the model of equation (9), the estimated coefficient $\hat{\beta}_{2}$ is the impact multiplier. The long-term multiplier can be calculated from (11) as

$$
\text { (12) } \theta=\frac{\hat{\beta}_{2}+\sum_{i=1}^{n^{*}} \hat{\beta}_{M, i}}{1-\sum_{i=1}^{k^{*}} \hat{\beta}_{L, i}}
$$


and the long run equation therefore has again the form of

$$
L_{t}=\theta_{0}+\theta M_{t}+u_{t}
$$

It is widely accepted that the time series for interest rates typically exhibit an I(1) property, that is unit root tests can not reject the null hypothesis of a random walk. Consequently, pass-through models like equation (11) are regularly estimated in first differences to avoid spurious regression problems.

Next to the standard pass-through specification, we propose to base pass-through measurement on a well specified error correction model that explicitly incorporates the long-run relationship between lending and money market rates provided the series are cointegrated ${ }^{13}$.

$$
\Delta L_{t}=\beta_{1}+\sum_{i=1}^{k^{*}} \beta_{L, i} \Delta L_{t-i}+\beta_{2} \Delta M_{t}+\sum_{i=1}^{n^{*}} \beta_{M, i} \Delta M_{t-i}+\beta_{E C T} E C T_{t-1}+\varepsilon_{t}
$$

where ECT contains the estimated residuals $\hat{\mathrm{u}}_{\mathrm{t}-1}$ from the long-run equilibrium relationship defined by equation (13), provided such a relationship can be established by cointegration testing procedures corresponding to those described in section 2.2.3.

This formulation has a number of advantages over the standard pass-through model of equation (11). First, as the long-run multiplier can directly be obtained from the co-integrating regression (13). Second, we can directly obtain the speed of adjustment towards the long-run equilibrium

\footnotetext{
${ }^{13}$ For details on the methodology see Sander and Kleimeier (2002).
} 
via the estimated coefficient of the ECT in equation (14). Third, this error correction specification allows us to analyze a variety of adjustment mechanisms - including the symmetric adjustment of the Engle-Granger cointegration methodology but also alternative asymmetric adjustment - thus showing more openly the differences in the financial part of the monetary transmission mechanism. Moreover, using models with asymmetries allows us to detect cointegration in cases where there are asymmetries and where the Engle-Granger methodology would thus fail to detect cointegration. Finally, only in cases where no cointegration is present in the data the standard pass-through model is appropriate.

In particular, we are considering here five different specifications for asymmetric adjustment of interest rates. The first model we consider is the threshold autoregressive model $\left(\mathrm{TAR}^{0}\right)$ developed by Tong (1983). The model makes a distinction whether the explained interest rate (lending rate in our case) is above or below its equilibrium level. Thus, the $\mathrm{TAR}^{0}$ allows for asymmetric adjustment depending on the state of equilibrium-deviation. For example, if the money market rate decreases without an immediate adjustment in the lending rate, we obtain a positive realization of the error term $u_{t}$. When in this case the autoregressive decay is faster than in the case of money market rate increases, then the lending rate adjustment is faster downward than upward. An appropriate test procedure is to set a Heaviside indicator $\mathrm{I}_{t}$ for different states of $\hat{\mathrm{u}}_{\mathrm{t}-1}$.

$$
\text { (15) } \quad I_{t}=\left\{\begin{array}{lll}
1 & \text { if } & \hat{u}_{t-1} \geq 0 \\
0 & \text { if } & \hat{u}_{t-1}<0
\end{array}\right.
$$


Using this definition, we test for cointegration by estimating equation (16), which represents a modification of the ADF test. The null of no cointegration is rejected if the estimated F-statistic for $\mathrm{H}_{0}: \rho_{1}=\rho_{2}=0$ based on critical values provided by Enders and Siklos (2000).

$$
\Delta \hat{u}_{t}=I_{t} \rho_{1} \hat{u}_{t-1}+\left(1-I_{t}\right) \rho_{2} \hat{u}_{t-1}+\sum_{i=1}^{m^{*}} \rho_{2+i} \Delta \hat{u}_{t-i}+\varepsilon_{t}
$$

The optimal lag length $\mathrm{m}^{*}$ is determined via the minimum AIC criteria for models with up to 4 lags. When cointegration is established, an F-test for equality of $\rho_{1}$ and $\rho_{2}$ indicates the presence of asymmetry.

The next model $(\mathrm{TAR} *)$ is a modification of the $\mathrm{TAR}^{0}$ in the sense that the threshold that was formerly implicitly set at zero is now allowed to deviate from that value. The rational behind such a non-zero threshold is that one or both variables may only adjust to a dis-equilibrium once it exceeds a certain minimum deviation in one direction. For example, the lending rate will adjust fast only when out of an equilibrium situation the money market rate drops in a way that the deviation from equilibrium exceeds an optimal threshold of, say, 0.5 percentage points. For lower deviations or increases in the money market rate, adjustment takes place at a significantly slower pace. Now the Heaviside indicator in conjunction with equation (16) ${ }^{14}$ is defined as

$$
\text { (17) } \quad I_{t}=\left\{\begin{array}{lll}
1 & \text { if } & \hat{u}_{t-1} \geq a_{0}^{*} \\
0 & \text { if } & \hat{u}_{t-1}<a_{0}^{*}
\end{array}\right.
$$

\footnotetext{
${ }^{14}$ For both, the $\mathrm{TAR}^{*}$ and the following B-TAR* model, the optimal lag length $\mathrm{m}^{*}$ of the $\mathrm{TAR}^{0}$ specification is used.
} 
In accordance with Chan's (1993), the optimal threshold $\mathrm{a}_{0} *$ is found by searching over the mid$80 \%$ of the distribution of $\hat{\mathrm{u}}_{\mathrm{t}}$ and selecting the model for which the residual sum of squares is minimized. Cointegration and asymmetry testing proceeds with the above described F-tests.

The third variation is a Band-TAR model (B-TAR*), which defines the Heaviside indicator as

$$
I_{1}=\left\{\begin{array}{clcccc}
I_{1}=1 & \text { if } & \hat{u}_{t-1} \geq a_{0}^{*} & \text { and } & 0 & \text { otherwise } \\
I_{2}=1 & \text { if } & \left|\hat{u}_{t-1}\right|<a_{0}^{*} & \text { and } & 0 & \text { otherwise } \\
I_{3}=1 & \text { if } & \hat{u}_{t-1}<-a_{0}^{*} & \text { and } & 0 & \text { otherwise }
\end{array}\right.
$$

while equation (16) has to be modified to

$$
\Delta \hat{u}_{t}=\sum_{j=1}^{3} \rho_{j} I_{j} \hat{u}_{t-1}+\sum_{i=1}^{m^{*}} \rho_{3+i} \Delta \hat{u}_{t-i}+\varepsilon_{t}
$$

Procedures for optimal lag length $\mathrm{m}^{*}$ and optimal threshold $\mathrm{a}_{0} *$ are corresponding to those of the TAR* and the F-tests for cointegration and asymmetry are applied to all three coefficient $\rho_{\mathrm{j}}$. Such a model has often been applied in particular to model interest rate cointegration where infrequent and discrete adjustments in the rates occur (Balke and Fomby 1997, Baum and Karasulu 1998). For example, if deviations from equilibrium are small and will therefore not lead to an adjustment of the dependent interest rate, one may find no cointegration within a narrow band bordered by $\mathrm{a}_{0} *$ and $-\mathrm{a}_{0} *$ while outside this band cointegration and thus an error correction mechanism may be present. In the context of our study, such behavior could be related to the 
"menu-cost" argument of lending rate stickiness such that banks only adjust lending rates when deviations are sufficiently large. However, if it would happen that inside the band cointegration is found but not outside, this could indicate that banks implicitly insure their customers against excessive deviations from equilibrium by smoothing the response of the lending rate.

In the TAR models the autoregressive decay always depends on the degree of deviation from equilibrium. One could also image situations where the adjustment speed depends on how fast the rates move away from or towards equilibrium. Enders and Granger (1998) therefore propose a momentum threshold autoregressive model (M-TAR) where the Heaviside indicator depends as follows on the change in error correction term, $\Delta \hat{\mathrm{u}}_{\mathrm{t}}$ :

$$
\text { (20) } I_{t}=\left\{\begin{array}{lll}
1 & \text { if } & \Delta \hat{u}_{t-1} \geq a_{0} \\
0 & \text { if } & \Delta \hat{u}_{t-1}<a_{0}
\end{array}\right.
$$

Similar to the $\mathrm{TAR}^{0}$ and $\mathrm{TAR}^{*}$ specifications, the threshold in the M-TAR can either be set at zero leading to the $\mathrm{M}-\mathrm{TAR}^{0}$ specification or be optimized at $\mathrm{a}_{0}$ * leading to the M-TAR* specification. Cointegration and asymmetry testing proceed based on equation (16) above. The M-TAR models have successfully been applied to the term structure of interest rates by Enders and Granger (1998) and Enders and Siklos (2000). According to the latter authors, M-TAR adjustment can be especially useful when decision makers (in our case banks) are viewed as attempting to smooth out large changes in a series. 
Based on the cointegration testing we selected the appropriate model for analyzing the passthrough of interest rates. In the case where no cointegration was found, we use the standard passthrough model (STD). This can be done by estimating the error correction model of equation (14) with $\beta_{\mathrm{ECT}}$ set to zero. For this as well as for all other specifications of equation (14), we have chosen an optimal lag length $\mathrm{k}^{*}$ and $\mathrm{n}^{*}$ for lending and money market rates, respectively, by applying the minimum AIC criteria for all models with up to 4 lags in either rate. Consequently, in the STD model the impact multiplier is given by the estimated coefficient $\hat{\beta}_{2}$ and the long-run multiplier $\theta$ is calculated according to equation (12).

When cointegration was found, the long-run multiplier $\theta$ is directly obtained from the cointegrating regression (13) while again the impact multiplier is $\hat{\beta}_{2}$ obtained from the appropriate specification of equation (14). The error correction mechanism itself depends on the optimal model. In the case of the symmetric cointegration model (SYM), the ECT is equal to the estimated residuals of the co-integrating regression. $\beta_{\mathrm{ECT}}$ is therefore estimating the speed of a symmetric adjustment process towards a long-run equilibrium. In the models with asymmetric adjustment, $\beta_{\mathrm{ECT}}$ and the ECTs are 2-dimensional or, in the case of the B-TAR*, 3-dimentional vectors which give the speed of adjustment depending on the definition of the ECTs of equations (15), (17), (18), or (20), respectively. Furthermore, where appropriate, the value of the optimal threshold $\mathrm{a}_{0} *$ is reported. 


\subsection{Evidence on Pass-Through in the Eurozone}

In investigating the pass-through in the Eurozone we estimate both the standard pass-through model of equation (11) as well as the well-specified error correction model for cases when lending and money market rates are cointegrated. Table 4 gives the details of the pass-through model selection. In case that neither symmetric nor asymmetric cointegration could be established, the standard pass-through model will be selected. If we find evidence for asymmetric cointegration, the TAR-type model that best fits the data based on the AIC criteria is chosen. These models are able to detect cointegration under condition of asymmetry and threshold behavior - cointegration that would otherwise remain undetected and could lead to a premature conclusion of limited competition in the banking sector. However, if the test statistics lead to a rejection of the asymmetry cointegration hypothesis, the symmetric error correction pass-through model is considered, cointegration provided. Based on this selection, the estimates of the pass-through models are given in Table 5 and visualized in Figures 6 and 7.

\section{TABLE 4 AND 5 ABOUT HERE}

Among the most important results are:

1. The impact multipliers are in most cases far below 1 indicating a limited pass-through of interest rate changes typically averaging between 0.3 for mortgage rates and slightly above 0.4 for consumer and corporate lending rates.

2. Even in the long run, the pass-through is far from perfect - that is, we do not always find a full pass-through. However, the long-run pass-through works best in corporate lending rates. This result corresponds to our findings in the cointegration analysis and points to the fact that 
next to a lack of cross-border lending a limited interest rate pass-through is the second cause for the lack of integration.

3. Comparing the size of the impact multipliers over time shows evidence for an increase in 5 out of 12 countries for mortgage rates. In the EMU period therefore, the average impact multiplier increased on average from 0.24 to 0.35 . Regarding consumer lending rates, it appears that the average value of the impact multipliers has decreased, however, this is compensated by an increased in the speed of adjustment as measured by the ECT coefficients. Regarding corporate lending rates, there is a slight increase of the average impact multiplier from 0.41 to 0.42 , but again supported by an additional increase in the average speed of adjustment, which among all rates shows the highest values. Again, this result which was already documented in our earlier study indicates that the pass-through mechanism has become faster after January 1999, a result also recently confirmed by an ECB study (de Bondt, 2002).

4. For all three rates, it is also evident from Figures 6 and 7 that the pass-through mechanism differs widely across countries in both, the short-run and the long-run, thus explaining not only the lack of integration but also the increasing evidence for cointegration in the presence of a single monetary policy. For example, during the pre-EMU period the heterogeneity as measured by the standard deviation of the long-term multipliers is the highest in consumer lending (0.56) followed by mortgage $(0.44)$ and corporate lending $(0.28)$. When moving into the EMU period, however, we find some evidence for a more homogeneous pass-through for mortgages and consumer lending as standard deviations fall to 0.33 and 0.28 , respectively. Again, this confirms our interpretation that an efficient and uniform pass-through process is the main force behind the cointegration evidence. 
5. The important novelty of our extended model is the analysis of the different nature of the adjustment process. The results show that there is no predominant model that fits all lending markets and countries. Rather, we find that in some cases lending rates are adjusting only when rates are sufficiently far from the equilibrium - that is, surpassing a certain threshold. In other cases, adjustment is differing when rates are moving upward or downward, or away or towards the equilibrium. In yet another case, adjustment takes place only when there is a fast and large movement away from equilibrium. For example looking to the EMU period, in corporate lending we find in 8 out of 12 cases either a symmetric adjustment or standard process. Only in Belgium, France, Portugal, and non-EMU member Sweden an asymmetric threshold adjustment model seems to be more adequate. For Sweden, however, the speed of adjustment could not be found significant. The results point to the fact that banks shields at least partially their corporate customers from rapid changes in interest rates. Turning now to EMU-period consumer lending rates we find no error correction mechanism in Belgium, Germany, Greece, a symmetric one in Austria, France, Portugal, Sweden, an asymmetric band adjustment in Spain, and a momentum asymmetric threshold adjustment in Denmark, Finland, and the UK. Again for EMU period, mortgage rates in most countries exhibit a standard pass-through (7 of 13) or a symmetric one (5 of 13). The only exception is France where a momentum threshold adjustment model seems to provide the best fit, indicating that banks only adjust lending rates when changes are fast and sufficiently large. This finding is consistent with the lack of cointegration in the mortgage market as such sluggish and differential adjustments can explain the lack of a common mortgage rate behavior in Europe.

FIGURE 6 AND 7 ABOUT HERE 
Summing up, the transmission process from money market interest rates to lending rates in the Eurozone exhibits strong national characteristics, which are rooted in the specific features of the national finance and banking systems. While there is some evidence for the emergence of a smoother pass-through process in the recent EMU years, it is still a far way from calling it a uniform banking system. These results are in line with the findings of a recent ECB study that suggests "that current 'country asymmetries' in response of bank rates to monetary policy should decrease over time by virtue of the implementation of the single monetary policy" (Mojon 2000). ${ }^{15}$ Overall, it appears that three factors are simultaneously important for creating a uniform retail banking market in the Eurozone: The first factor is the potential impact of the single currency as suggested above. Secondly, further harmonization of national legislation in particular in the area of consumer credit where harmonization accomplished so far is limited (Diez Guardia 2000). Along similar lines, national differences in taxation also go some way in explaining the lack of arbitrage, in particular for mortgage lending. Thirdly, additional regulatory efforts and pro-competition measures are needed to promote a smooth and more uniform pass-through of monetary policy changes.

\section{CONCLUSIONS}

Our study provides new evidence on the emergence of unified European retail banking market. The first point we stress is that the empirical artifact of converging nominal and real lending rates cannot simply be read as a sign for an integrating retail banking market. Such rates follow often with considerable delay - the changes in central bank-determined interest rates, that is, convergence of lending rates could be the consequence of convergence of monetary policy and

\footnotetext{
${ }^{15}$ See also de Bondt (2002) who reports a smoother pass-through mechanism in the Eurozone after January 1999.
} 
not of market integration. Secondly, we therefore suggest to base judgment on the existence of a uniform banking market on a cointegration analysis. Doing so, we find very limited evidence for cointegration in particular before January 1,1999 , that is the introduction of the single currency. The $2^{\text {nd }} \mathrm{BD}$ and other regulation efforts in order to create a single lending market appear to have been of a limited effect in this respect. Third, we find that the relationship of national lending markets with the remaining Eurozone lending markets exhibits strong signs of structural changes that have come along with the introduction of the single currency on January 1,1999 . This result should not be underestimated as it indicates that Eurozone credit markets are changing dramatically. Forth, we provide a first picture of the emerging (uniform) Eurozone banking market based on the data available so far. However, our results based now on more than three years experience with the single currency are confirming the findings of our earlier study, thus pointing to a certain level of robustness of the proposition that the Euro has the potential to unify financial markets. We found, fifth, that there are some tendencies for a more uniform corporate lending market, while consumer and mortgage lending markets are still more fragmented. Sixth, we identify three driving forces towards a uniform banking market: Cross border borrowing and lending (arbitrage), a national and international retail banking environment, and a smooth and uniform pass-through of interest rate changes onto lending rates. Regarding the first point, lending is still a very much localized activity and may eventually remain so. For an effective arbitrage process a much higher level of harmonization is needed, in particular in the field of consumer credit. If, however, cross-border lending is limited this lack of internationalization of lending could have been healed by a competitive behavior of loan pricing. On the one hand, increased competition would decrease lending spreads. Our descriptive analysis of interest rate spreads has delivered no clear evidence in favor of the increased competition hypothesis and is in 
line with the more sophisticated empirical work by Corvoisier and Gropp (2001). On the other hand, more competition should lead to a smoother pass-through of monetary policy changes onto borrowers in particular with respect to lending to the corporate sector. Consequently, improving the competitive environment in retail banking could not only benefit the borrowers a lot but also help to unify the Eurozone retail banking market.

Integrating financial markets legally is in itself not a guarantee that a competitive and more uniform retail lending markets will be established throughout the Eurozone. It is in this context that a recent "report by the Economic and Financial Committee on EU Financial Integration" states that "[o]nly if integration results in a genuine increase in the level of competition will efficiency gains translate into lower capital cost for borrowers ..." (Economic and Financial Committee 2002:3). The committee therefore also remarks that "to accompany the transition to an integrated financial market, the competent competition authorities must be fully prepared to respond to the evolving structure of the EU's financial markets, including by addressing uncompetitive structures and arrangements resulting from the inheritance of national markets in financial services." (Economic and Financial Committee 2002:22).

However, our results also suggest that the introduction of the single currency already had and will most likely continue to have an important impact on the emergence of a single Eurozone retail banking market. In what direction these developments will go, needs to be monitored closely for all different retail lending products in order to obtain the benefits promised earlier with the single market initiative as well as to promote the smooth functioning of the single monetary policy. 


\section{ACKNOWLEDGEMENTS}

An earlier analysis of this issue has been conducted for the European Credit Research Institute (ECRI) and has been published as ECRI Research Report No.2. For valuable comments the authors wish to thank the anonymous referees and the participants of the ECRI research seminar, Brussels, September 2001; X International 'Tor Vergata' Conference on Banking and Finance, Rome, December 2001; Contemporary Europe Research Centre (CERC) of the University of Melbourne, Melbourne, February 2002; Staff Seminar at the School of Economics and Finance, University of Western Sydney, Sydney, April 2002; Workshop of the ECB-CFS Research Network on "Capital Markets and Financial Integration in Europe", Frankfurt, April 2002; Munich Research Seminar at the economics department (in cooperation with CES) at the Ludwig-Maximilian, University of Munich, Munich, April 2002; and European Economics Association Conference, Venice, August 2002. As always, all the usual disclaimers apply. 


\section{APPENDIX - DATA SOURCES}

Our study mainly relies on monthly national retail interest rates that have been obtained from ECB. The ECB collects three consumer lending rates: overdrafts on cash accounts (series N1), mortgage loans to households (series N2), and consumer loans to households (series N3). As the series N1 is only available for France and Ireland, we are forced to focus on the remaining series $\mathrm{N} 2$ and N3. With regards to corporate lending rates we use the series N4 'short-term loans to enterprises'. These series are available for the EMU member countries Austria, Belgium, Finland, France, Germany, Greece, Ireland, Italy, Netherlands, Portugal, and Spain and for Denmark, Sweden, and the United Kingdom as non-EMU EU countries. The series N4 for Denmark and N3 for Sweden and Denmark are available from the ECB's publication "Selected retail interest rates from the non-Euro area EU countries. Note, however, that the following series are missing: N2 for Denmark, N3 for Ireland, Italy, and the Netherlands, N4 for Finland and the UK. Furthermore, the following series are only available as quarterly data: N2 for France and Sweden, N3 for Denmark, France and Sweden, N4 for Denmark and Sweden. In these cases, we assume that interest rates are constant during the given quarter and thus convert the quarterly to a monthly frequency by filling in the missing values. For the UK and Sweden several different $\mathrm{N} 2$ series are available and the series 2.3 and 2.1 have been chosen, respectively, as the relevant mortgage rate. For the UK several different N3 series are available and the series 3.1 has been chosen as the relevant consumer lending rate. For Belgium, Italy, and Portugal several different $\mathrm{N} 4$ series are available and the series 4.1, 4.1, and 4.2 have been chosen, respectively, as the relevant corporate lending rate. Finally, whereas some national series start as early as 1980, data for all EMU member countries is available only as of April 1995. Thus we decided to focus on the period from April 1995 until April 2002. 
Based on these nominal interest rate series, real interest rates are calculated by deducting inflation rates. Inflation rates are calculated as the percentage change in the consumer price index (CPI) which is obtained from the CD-ROM version of the International Financial Statistics (IFS) published by the International Monetary Fund (IMF). From January 1996 until April 2002, a harmonized consumer price index (HCPI) as given in the IFS's line 64H is available for all EU countries and has been used. Before January 1996, the national CPI of line 64 is used. Exceptions to this rule are the following: For Portugal, national CPI data are used until December 1998 and HCPI is used starting January 1999. For Ireland, no CPI data are available. Thus, inflation rates are calculated based on wholesale prices until December 1998 and HCPI is used starting January 1999.

In order to calculate European weighted averages for the nominal and real interest rate series N2, N3, and N4, weights for each country have to be found. These weights should appropriately reflect the relative economics importance of the Eurozone countries. We therefore work with the OECD (2000) weighting scheme for aggregate measures, which is based on 1995 GDP and purchasing power parities. The weights are 0.82 for Austria, 1.05 for Belgium, 0.46 for Finland, 5.72 for France, 8.33 for Germany, 0.31 for Ireland, 5.49 for Italy, 1.57 for the Netherlands, 0.65 for Portugal, and 2.84 for Spain. Note that when estimating equation (4), the country under investigation is excluded from the European average and the weights are re-scaled to sum up to 100 per cent. Note that as Greece did not join EMU until January 2001, it has not been included in the weighted averages. 
Finally, money market rates are obtained from line 60b of the CD-ROM version of the IMF's IFS. National rates for EMU member countries are used until December 1998 but due to the convergence of money market rates under the single currency, Euro area rates have been used as of January 1999. For Greece, national rates are available only from January 1998 to October 1999. After October 1999, Euro area rates have been used instead. For non-EMU member countries, the national rates have been used for the full time period.

This sample selection leads to series without any missing values for all EMU member countries. However, the series for the non-EMU member countries show some missing values. In particular the following series are not available for the full time period of 4/95 to 4/02: Mortgage lending rates (N2): Nominal rates, real rates and spreads for Greece (1/99-4/02), Sweden (1/96-9/01), UK (4/95-3/02). Consumer lending rates (N3): Nominal rates, real rates and spreads for Denmark (10/95-12/01), Greece (1/99-4/02), Sweden (10/95-9/01). Corporate lending rates (N4): Nominal rates, real rates and spreads for Denmark (4/95-12/01), Sweden (4/95-9/01), nominal rates for Greece (4/95-4/04) and real rates and spreads for Greece (1/98-4/02). 
APPENDIX - TABLES AND FIGURES

TABLE A1, A2, A3 ABOUT HERE

FIGURE A1, A2 ABOUT HERE 


\section{REFERENCES}

Andrews, D.W. K, 1993. Tests for parameter instability and structural change with an unknown change point. Econometrica 61, 821--856.

Balke, N.S., Fomby, T.B., 1997. Threshold cointegration. International Economic Review 38, 627--645.

Baum, C.F., Karasulu, M, 1998. Modelling Federal Reserve discount policy. Computational Economics 11, 53--70.

Berger, A.N., Demsetz, R.S.,Strahan, P.E., 1999. The consolidation of the financial services industry: Causes, consequences, and implication for the future. Journal of Banking and Finance 23, 135--194.

Bredemeier, S., 1995. Integration within the banking sector, in: Lang, F.P., Ohr, R. (Eds.) International Economic Integration, Physica Verlag, Heidelberg., pp. 159--180.

Chan, K.S., 1993. Consistency and limiting distribution of the least squares estimator of a threshold autroregressive model. The Annals of Statistics 21, 520--533.

Commission of the European Communities, 1988. European economy: The economics of 1992, No. 35.Commission of the European Communities, Brussels.

Corvoisier, S.,Gropp, R, 2001. Bank concentration and retail interest rates. ECB working paper no. 72 .

Cottarelli, C., Kourelis, A, 1994. Financial structure, bank lending rates, and the transmission mechanism of monetary policy. IMF Staff Papers 41, No 4.

De Bondt, G., 1998. Financial structure: Theories and stylised facts for six EU countries. De Economist 146, 271--300. 
De Bondt, G., 2002. Retail bank interest rate pass-through: New evidence at the Euro area level. ECB working paper no. 136.

Diebold, F.X.,Chen, C, 1996. Testing structural stability with endogenous breakpoint - A size comparison of analytic and bootstrap procedures. Journal of Econometrics 70, 221--241.

Diez-Guardia, N., 2000. ECRI Research Report No.1: Consumer credit in the EU. European Credit Research Institute, Brussels.

Economic and Financial Committee, 2002. Report by the Economic and Financial Committee (ETC) on EU financial integration.. European Commission, Directorate-General for Economic and Financial Affairs, Brussels, Economic Papers No. 171.

Enders, W.,Granger, C.W.J., 1998. Unit root tests and asymmetric adjustment with an example using the term structure of interest rates. Journal of Business and Economic Statistics 16, 304--311.

Enders, W., Siklos, P.I., 2000. Cointegration and threshold adjustment. Working paper.

Engle, R.F., Granger, C.W.J., 1987. Cointegration and error correction: Representation, estimation, and testing. Econometrica 55, 251--276.

European Central Bank, 1999a. Possible Effects of EMU on the EU banking system in the medium and long term. February.

European Central Bank, 1999b. Banking in the euro area: Structural features and trends. ECB Monthly Bulletin, April, pp. 41--53.

European Central Bank, 1999c. The effects of technology on the EU banking systems. July.

European Central Bank, 2000a. The euro area one year after the introduction of the euro: Key characteristics and changes in the financial structure. ECB Monthly Bulletin, January, pp. 35--49. 
European Central Bank, 2000b. EMU and banking supervision. ECB Monthly Bulletin, April, pp. 49--64.

Gregory, A.W., Nason, J.M.,Watt, D.G., 1996. Testing for structural breaks in co-integrated relationships. Journal of Econometrics 71, 321--341.

Hansen, B.E., 1992. Tests for parameter instability in regressions with I(1) processes. Journal of Business \& Economic Statistic 10, 321--335.

Kleimeier, S., 2001. Banking in western Europe, in: M. Warner (Ed.), International Encyclopedia of Business and Management, $2^{\text {nd }}$ edition, Thomson Learning, London, pp. 421--429.

Kleimeier, S., Sander, H., 2000. Regionalisation versus globalisation in European financial market integration: Evidence from cointegration analysis. Journal of Banking and Finance 24, 1005--1043.

Kleimeier, S., Sander, H., 2001, ECRI Research Report No. 2: Consumer Credit in the Eurozone: Evidence on the Emergence of a Single Eurozone Retail Banking Market., European Credit Research Institute, Brussels.

Marois, B., 1997. French banks and European strategy. European Management Journal 15, 183-189.

Mojon, B., 2000. Financial structure and the interest rate channel of ECB monetary policy. ECB working paper, No. 40, November.

OECD, 2000. OECD Economic Outlook No. 68, p. 206.

Padoa-Schioppa, T., 2000. Is a euroland banking system already emerging?, Lecture at the Société Universitaire Européenne de Recherches Financières, Vienna 29 April, European Central Bank (www.ecb.int/key/00/sp000429.htm). 
Quandt, R., 1960. Tests of the hypothesis that a linear regression system obeys two separate regimes. Journal of the American Statistical Association 55, 324--330.

Sander, H., Kleimeier, S., 2002. Asymmetric adjustment of commercial bank interest rates in the Euro area: An empirical investigation into interest rate pass-through. Kredit und Kapital $35,161-192$.

Tong, H., 1983. Threshold models in non-linear time series: Lecture Notes in Statistics 21, Springer Verlag, Berlin.

Tourani Rad, A., van Beek, L., 1999. Market valuation of European bank mergers. European Management Journal 17, 532--540.

Zimmerman, G.C., 1995. Implementing the single banking market in Europe. Federal Reserve Bank of San Francisco Economic Review 3, 35--51. 


\begin{tabular}{|c|c|c|c|c|c|c|}
\hline \multirow[b]{2}{*}{ target } & \multicolumn{2}{|c|}{ commercial bank } & \multicolumn{2}{|c|}{ acquirer } & \multicolumn{2}{|c|}{ insurance company } \\
\hline & value & $\%$ of total & value & $\%$ of total & value & $\%$ of total \\
\hline \multicolumn{7}{|c|}{ Panel A: Domestic M\&As } \\
\hline commercial bank & 89.0 & 36.0 & 23.0 & 9.3 & 11.0 & 4.4 \\
\hline securities firm & 9.0 & 3.6 & 19.0 & 7.7 & 6.0 & 2.4 \\
\hline insurance company & 20.0 & 8.1 & 24.0 & 9.7 & 46.0 & 18.6 \\
\hline \multicolumn{7}{|c|}{ Panel B: Intra-European M\&As } \\
\hline commercial bank & 15.0 & 17.9 & 4.3 & 5.1 & 11.2 & 13.4 \\
\hline securities firm & 8.7 & 10.4 & 5.8 & 6.9 & 0.3 & 0.4 \\
\hline insurance company & 0.4 & 0.5 & 1.1 & 1.3 & 37.0 & 44.2 \\
\hline \multicolumn{7}{|c|}{ Panel C: Europe-Non-Europe M\&As } \\
\hline commercial bank & 14.5 & 14.5 & 15.6 & 15.6 & 1.0 & 1.0 \\
\hline securities firm & 4.3 & 4.3 & 15.9 & 15.9 & 3.1 & 3.1 \\
\hline insurance company & 0.3 & 0.3 & 12.9 & 12.9 & 32.7 & 32.7 \\
\hline
\end{tabular}

Source: Berger, Demsetz, and Strahan (1999). Values are given in billion of US dollar. For each panel, the per cent figures sum to 100 . 
Table 2: Structural Breaks in the Cointegration Relationship

\begin{tabular}{|c|c|c|c|c|c|c|}
\hline \multirow[t]{2}{*}{ Country } & \multicolumn{2}{|c|}{ Mortgage Lending Rates } & \multicolumn{2}{|c|}{ Consumer Lending Rates } & \multicolumn{2}{|c|}{ Corporate Lending Rates } \\
\hline & $\begin{array}{c}\text { Rolling } \\
\text { Chow F-test }\end{array}$ & $\begin{array}{c}\text { Break point } \\
\text { (mm/yy) }\end{array}$ & $\begin{array}{c}\text { Rolling } \\
\text { Chow F-test }\end{array}$ & $\begin{array}{l}\text { Break point } \\
\text { (mm/yy) }\end{array}$ & $\begin{array}{c}\text { Rolling } \\
\text { Chow F-test }\end{array}$ & $\begin{array}{c}\text { Break point } \\
\text { (mm/yy) }\end{array}$ \\
\hline \multicolumn{7}{|c|}{ Panel A: Nominal Lending Rates } \\
\hline Austria & 27.76 & $01 / 98$ & 34.91 & $02 / 98$ & 24.96 & $11 / 96$ \\
\hline Belgium & 112.74 & $05 / 99$ & 121.05 & $12 / 95$ & 54.52 & $06 / 97$ \\
\hline Denmark & & & 43.87 & $03 / 98$ & 89.54 & $04 / 98$ \\
\hline Finland & 45.31 & $09 / 97$ & 19.37 & $05 / 00$ & & \\
\hline France & 14.29 & $(06 / 99)$ & 55.81 & $06 / 98$ & 23.60 & 03.97 \\
\hline Germany & 62.56 & $06 / 99$ & 38.75 & $08 / 00$ & 253.28 & $03 / 00$ \\
\hline Greece & 118.96 & $11 / 00$ & 168.55 & $02 / 01$ & 340.32 & $03 / 00$ \\
\hline Ireland & 62.55 & $01 / 98$ & & & 98.56 & $09 / 98$ \\
\hline Italy & 153.35 & $05 / 98$ & & & 367.97 & $11 / 98$ \\
\hline Netherlands & 48.97 & $07 / 99$ & & & 122.89 & $11 / 98$ \\
\hline Portugal & 63.81 & $01 / 97$ & 733.21 & $04 / 98$ & 375.26 & $05 / 99$ \\
\hline Spain & 82.20 & 03/97 & 623.64 & $01 / 00$ & 57.68 & $02 / 97$ \\
\hline Sweden & 32.86 & $06 / 99$ & 25.58 & $09 / 96$ & 62.76 & $05 / 99$ \\
\hline United Kingdom & 48.28 & $11 / 00$ & 124.75 & $12 / 98$ & & \\
\hline \multicolumn{7}{|c|}{ Panel B: Real Lending Rates } \\
\hline Austria & 44.24 & $07 / 99$ & 25.77 & $12 / 96$ & 39.52 & $11 / 99$ \\
\hline Belgium & 50.67 & $07 / 97$ & 145.02 & $12 / 95$ & 51.65 & $06 / 97$ \\
\hline Denmark & & & 13.65 & $(06 / 00)$ & 28.40 & $06 / 00$ \\
\hline Finland & 81.35 & $02 / 96$ & 32.47 & $07 / 96$ & & \\
\hline France & 11.16 & - & 22.90 & 06/01 & 34.45 & $11 / 98$ \\
\hline Germany & 17.39 & $01 / 00$ & 14.94 & $(11 / 99)$ & 23.53 & $12 / 97$ \\
\hline Greece & 15.78 & $(09 / 00)$ & 93.72 & $06 / 00$ & 120.96 & $09 / 00$ \\
\hline Ireland & 31.50 & $12 / 98$ & & & 98.56 & $09 / 98$ \\
\hline Italy & 106.67 & $03 / 98$ & & & 144.83 & $02 / 98$ \\
\hline Netherlands & 90.74 & $12 / 00$ & & & 77.13 & $12 / 00$ \\
\hline Portugal & 48.58 & $11 / 97$ & 114.51 & 03/98 & 50.19 & $05 / 98$ \\
\hline Spain & 30.72 & $12 / 00$ & 46.60 & 11.97 & 17.34 & $03 / 96$ \\
\hline Sweden & 32.11 & $03 / 98$ & 25.60 & $02 / 97$ & 27.94 & $03 / 98$ \\
\hline United Kingdom & 28.13 & $09 / 99$ & 33.75 & $12 / 98$ & & \\
\hline
\end{tabular}

Note: Parentheses indicate that a breakpoint is only marginally significant. 
Table 3: Cointegration of Lending Rates

\begin{tabular}{|c|c|c|c|c|c|c|c|c|c|c|c|c|c|}
\hline \multirow[b]{3}{*}{ Country } & \multirow[b]{3}{*}{ Period } & \multicolumn{4}{|c|}{ Mortgage Lending Rates } & \multicolumn{4}{|c|}{ Consumer Lending Rates } & \multicolumn{4}{|c|}{ Corporate Lending Rates } \\
\hline & & \multicolumn{2}{|c|}{ nom } & \multicolumn{2}{|c|}{ real } & \multicolumn{2}{|c|}{ nom } & \multicolumn{2}{|c|}{ real } & \multicolumn{2}{|c|}{ nom } & \multicolumn{2}{|c|}{ real } \\
\hline & & coint? & $\begin{array}{c}\beta_{\mathrm{ECT}} \\
(\mathrm{t}-\mathrm{stat}) \\
\end{array}$ & coint? & $\begin{array}{c}\beta_{\mathrm{ECT}} \\
(\mathrm{t}-\mathrm{stat}) \\
\end{array}$ & coint? & $\begin{array}{c}\beta_{\mathrm{ECT}} \\
(\mathrm{t}-\mathrm{stat}) \\
\end{array}$ & coint? & $\begin{array}{c}\beta_{\mathrm{ECT}} \\
(\mathrm{t}-\mathrm{stat}) \\
\end{array}$ & coint? & $\begin{array}{c}\beta_{\mathrm{ECT}} \\
(\mathrm{t}-\mathrm{stat}) \\
\end{array}$ & coint? & $\begin{array}{c}\beta_{\mathrm{ECT}} \\
(\mathrm{t}-\mathrm{stat}) \\
\end{array}$ \\
\hline \multirow[t]{4}{*}{ Austria } & full & no & $\begin{array}{c}-0.113 \\
(-3.950)\end{array}$ & yes & $\begin{array}{c}-0.237 \\
(-3.154)\end{array}$ & no & $\begin{array}{c}-1.778 \\
(-3.842)\end{array}$ & yes & $\begin{array}{c}-0.197 \\
(-2.501)\end{array}$ & no & $\begin{array}{c}0.017 \\
(0.241)\end{array}$ & yes & $\begin{array}{c}-0.201 \\
(-2.497)\end{array}$ \\
\hline & pre-EMU & no & $\begin{array}{c}-0.091 \\
(-1.701)\end{array}$ & yes & $\begin{array}{c}-0.375 \\
(-2.776)\end{array}$ & no & $\begin{array}{c}-0.141 \\
(-1.591)\end{array}$ & yes & $\begin{array}{c}-0.292 \\
(-2.369)\end{array}$ & no & $\begin{array}{c}-0.133 \\
(-1.709)\end{array}$ & yes & $\begin{array}{c}-0.422 \\
(-3.264)\end{array}$ \\
\hline & EMU & no & $\begin{array}{c}-0.417 \\
(-8.797)\end{array}$ & yes & $\begin{array}{c}-0.385 \\
(-2.932)\end{array}$ & no & $\begin{array}{c}0.057 \\
-0.496\end{array}$ & yes & $\begin{array}{c}-0.428 \\
(-3.362)\end{array}$ & no & $\begin{array}{c}0.159 \\
(1.096)\end{array}$ & yes & $\begin{array}{c}-0.245 \\
(-1.944)\end{array}$ \\
\hline & postbreak & & & yes & $\begin{array}{c}-0.600 \\
(-3.000)\end{array}$ & & & & & & & yes & $\begin{array}{c}-0.543 \\
(-2.150)\end{array}$ \\
\hline \multirow[t]{4}{*}{ Belgium } & full & no & $\begin{array}{c}-0.143 \\
(-4.141)\end{array}$ & yes & $\begin{array}{c}-0.152 \\
(-2.547)\end{array}$ & no & $\begin{array}{c}-0.177 \\
(-3.094)\end{array}$ & no & $\begin{array}{c}-0.119 \\
(-2.144)\end{array}$ & no & $\begin{array}{c}-0.140 \\
(-3.578)\end{array}$ & no & $\begin{array}{c}-0.136 \\
(-2.415)\end{array}$ \\
\hline & pre-EMU & no & $\begin{array}{c}-0.178 \\
(-2.748)\end{array}$ & no & $\begin{array}{c}-0.111 \\
(-1.573)\end{array}$ & no & $\begin{array}{c}-0.224 \\
(-2.537)\end{array}$ & no & $\begin{array}{c}-0.085 \\
(-1.075)\end{array}$ & yes & $\begin{array}{c}-0.168 \\
(-3.381)\end{array}$ & no & $\begin{array}{c}-0.085 \\
(-1.419)\end{array}$ \\
\hline & EMU & no & $\begin{array}{c}-0.093 \\
(-1.065)\end{array}$ & yes & $\begin{array}{c}-0.268 \\
(-2.099)\end{array}$ & no & $\begin{array}{c}-0.084 \\
(-1.059)\end{array}$ & yes & $\begin{array}{c}-0.205 \\
(-1.495)\end{array}$ & no & $\begin{array}{c}0.167 \\
(1.839)\end{array}$ & yes & $\begin{array}{c}-0.626 \\
(-3.892)\end{array}$ \\
\hline & postbreak & yes & $\begin{array}{c}-0.437 \\
(-3.684)\end{array}$ & & & & & & & & & & \\
\hline \multirow[t]{4}{*}{ Denmark } & full & & & & & no & $\begin{array}{c}-0.214 \\
(-3.565)\end{array}$ & no & $\begin{array}{c}-0.109 \\
(-1.817)\end{array}$ & no & $\begin{array}{c}-0.135 \\
(-2.360)\end{array}$ & no & $\begin{array}{c}-0.128 \\
(-2.290)\end{array}$ \\
\hline & pre-EMU & & & & & no & $\begin{array}{c}-0.067 \\
(-0.897)\end{array}$ & no & $\begin{array}{c}-0.05 \\
(-0.642)\end{array}$ & no & $\begin{array}{c}-0.047 \\
(-0.457)\end{array}$ & no & $\begin{array}{c}-0.065 \\
(-0.788)\end{array}$ \\
\hline & EMU & & & & & yes & $\begin{array}{c}-0.119 \\
(-0.838)\end{array}$ & no & $\begin{array}{c}-0.177 \\
(-1.935)\end{array}$ & yes & $\begin{array}{c}-0.786 \\
(-4.526)\end{array}$ & no & $\begin{array}{c}-0.069 \\
(-0.827)\end{array}$ \\
\hline & postbreak & & & & & & & yes & $\begin{array}{c}-0.488 \\
(-2.111)\end{array}$ & & & yes & $\begin{array}{c}-0.914 \\
(-5.194)\end{array}$ \\
\hline \multirow[t]{4}{*}{ Finland } & full & no & $\begin{array}{c}-0.081 \\
(-2.754)\end{array}$ & no & $\begin{array}{c}0.067 \\
(-1.525)\end{array}$ & yes & $\begin{array}{c}-0.132 \\
(-1.913)\end{array}$ & yes & $\begin{array}{c}-0.129 \\
(-1.798)\end{array}$ & & & & \\
\hline & pre-EMU & no & $\begin{array}{c}-0.052 \\
(-1.553)\end{array}$ & no & $\begin{array}{c}-0.027 \\
(-0.488)\end{array}$ & yes & $\begin{array}{c}-0.312 \\
(-2.587)\end{array}$ & yes & $\begin{array}{c}-0.531 \\
(-2.647)\end{array}$ & & & & \\
\hline & EMU & no & $\begin{array}{c}-0.222 \\
(-2.365)\end{array}$ & no & $\begin{array}{c}-0.262 \\
(-2.378)\end{array}$ & no & $\begin{array}{c}0.146 \\
(1.822)\end{array}$ & no & $\begin{array}{c}-0.145 \\
(-1.372)\end{array}$ & & & & \\
\hline & postbreak & & & & & no & $\begin{array}{c}0.227 \\
(2.168)\end{array}$ & & & & & & \\
\hline \multirow[t]{4}{*}{ France } & full & yes & $\begin{array}{c}-0.368 \\
(-5.713)\end{array}$ & yes & $\begin{array}{c}-0.206 \\
(-2.723)\end{array}$ & yes & $\begin{array}{c}-0.198 \\
(-4.087)\end{array}$ & yes & $\begin{array}{c}-0.175 \\
(-1.862)\end{array}$ & yes & $\begin{array}{c}-0.117 \\
(-1.924)\end{array}$ & yes & $\begin{array}{c}-0.164 \\
(-2.623)\end{array}$ \\
\hline & pre-EMU & yes & $\begin{array}{c}-0.296 \\
(-3.182)\end{array}$ & yes & $\begin{array}{c}-0.227 \\
(-2.349)\end{array}$ & yes & $\begin{array}{c}-0.32 \\
(-3.816)\end{array}$ & yes & $\begin{array}{c}-0.306 \\
(-2.377)\end{array}$ & yes & $\begin{array}{c}-0.212 \\
(-0.268)\end{array}$ & yes & $\begin{array}{c}-0.186 \\
(-1.991)\end{array}$ \\
\hline & EMU & yes & $\begin{array}{c}-0.405 \\
(-4.223)\end{array}$ & yes & $\begin{array}{c}-0.363 \\
(-3.085)\end{array}$ & yes & $\begin{array}{c}-0.196 \\
(-1.994)\end{array}$ & yes & $\begin{array}{c}-0.114 \\
(-0.954)\end{array}$ & yes & $\begin{array}{c}-0.172 \\
(-1.041)\end{array}$ & yes & $\begin{array}{c}-0.402 \\
(-2.298)\end{array}$ \\
\hline & postbreak & yes & $\begin{array}{c}-0.561 \\
(-4.074)\end{array}$ & & & & & yes & $\begin{array}{c}-0.554 \\
(-1.604)\end{array}$ & & & & \\
\hline
\end{tabular}


Table 3 continued: Cointegration of Lending Rates

\begin{tabular}{|c|c|c|c|c|c|c|c|c|c|c|c|c|c|}
\hline \multirow[b]{3}{*}{ Country } & \multirow[b]{3}{*}{ Period } & \multicolumn{4}{|c|}{ Mortgage Lending Rates } & \multicolumn{4}{|c|}{ Consumer Lending Rates } & \multicolumn{4}{|c|}{ Corporate Lending Rates } \\
\hline & & \multicolumn{2}{|c|}{ nom } & \multicolumn{2}{|c|}{ real } & \multicolumn{2}{|c|}{ nom } & \multicolumn{2}{|c|}{ real } & \multicolumn{2}{|c|}{ nom } & \multicolumn{2}{|c|}{ real } \\
\hline & & coint? & $\begin{array}{c}\beta_{\mathrm{ECT}} \\
\text { (t-stat) }\end{array}$ & coint? & $\begin{array}{c}\beta_{\mathrm{ECT}} \\
(\mathrm{t}-\mathrm{stat})\end{array}$ & coint? & $\begin{array}{c}\beta_{\mathrm{ECT}} \\
(\mathrm{t}-\mathrm{stat})\end{array}$ & coint? & $\begin{array}{c}\beta_{\mathrm{ECT}} \\
\text { (t-stat) }\end{array}$ & coint? & $\begin{array}{c}\beta_{\mathrm{ECT}} \\
\text { (t-stat) }\end{array}$ & coint? & $\begin{array}{c}\beta_{\mathrm{ECT}} \\
(\mathrm{t}-\mathrm{stat})\end{array}$ \\
\hline \multirow[t]{8}{*}{ Germany } & full & no & -0.136 & no & -0.107 & no & -0.009 & no & -0.182 & no & -0.032 & yes & -0.241 \\
\hline & & & $(-3.044)$ & & $(-1.904)$ & & $(-2.089)$ & & $(-2.778)$ & & $(-1.637)$ & & $(-3.277)$ \\
\hline & pre-EMU & yes & -0.197 & no & -0.127 & yes & -0.068 & no & -0.107 & no & -0.147 & no & -0.19 \\
\hline & & & $(-2.909)$ & & $(-1.801)$ & & $(-0.877)$ & & $(-1.239)$ & & $(-2.166)$ & & $(-2.131)$ \\
\hline & EMU & no & 0.056 & no & -0.073 & no & -0.057 & no & -0.161 & no & -0.042 & yes & -0.334 \\
\hline & & & $(0.740)$ & & $(-0.766)$ & & $(-1.230)$ & & $(-1.360)$ & & $(-0.776)$ & & $(-2.663)$ \\
\hline & postbreak & no & -0.058 & no & -0.147 & yes & -0.411 & yes & -0.352 & no & -0.378 & & \\
\hline & & & $(-0.648)$ & & $(-1.087)$ & & $(-4.322)$ & & $(-2.233)$ & & $(-4.553)$ & & \\
\hline \multirow[t]{4}{*}{ Greece } & EMU & no & 0.017 & yes & -0.13 & no & -0.079 & no & -0.068 & no & -0.062 & no & -0.005 \\
\hline & & & $(0.874)$ & & $(-1.415)$ & & $(-2.383)$ & & $(-2.082)$ & & $(-2.493)$ & & $(-0.191)$ \\
\hline & postbreak & yes & -0.088 & yes & -0.4 & yes & -0.256 & yes & -0.271 & no & -0.055 & yes & -0.274 \\
\hline & & & $(-0.637)$ & & $(-2.439)$ & & $(-1.806)$ & & $(-4.504)$ & & $(-2.201)$ & & $(-2.507)$ \\
\hline \multirow[t]{6}{*}{ Ireland } & full & no & -0.067 & no & -0.115 & & & & & no & -0.077 & no & -0.123 \\
\hline & & & $(-2.405)$ & & $(-2.509)$ & & & & & & $(-2.152)$ & & $(-2.461)$ \\
\hline & pre-EMU & no & -0.132 & yes & -0.182 & & & & & no & -0.128 & no & -0.199 \\
\hline & & & $(-2.069)$ & & $(-2.070)$ & & & & & & $(-1.622)$ & & $(-2.317)$ \\
\hline & EMU & no & -0.150 & no & -0.084 & & & & & yes & -0.712 & yes & -0.165 \\
\hline & & & $(-2.258)$ & & $(-1.445)$ & & & & & & $(-4.220)$ & & $(-2.242)$ \\
\hline \multirow[t]{6}{*}{ Italy } & full & no & -0.108 & no & -0.048 & & & & & no & -0.021 & no & -0.04 \\
\hline & & & $(-5.732)$ & & $(-1.743)$ & & & & & & $(-2.718)$ & & $(-1.744)$ \\
\hline & pre-EMU & no & -0.054 & no & 0.014 & & & & & no & -0.016 & no & 0.018 \\
\hline & & & $(-0.964)$ & & -0.37 & & & & & & $(-0.628)$ & & -0.536 \\
\hline & EMU & no & -0.263 & yes & -0.274 & & & & & yes & -0.321 & yes & -0.29 \\
\hline & & & $(-3.832)$ & & $(-2.483)$ & & & & & & $(-4.367)$ & & $(-2.821)$ \\
\hline \multirow[t]{8}{*}{ Netherlands } & full & no & -0.175 & no & -0.075 & & & & & no & -0.059 & no & -0.053 \\
\hline & & & $(-4.229)$ & & $(-1.829)$ & & & & & & $(-2.359)$ & & $(-1.143)$ \\
\hline & pre-EMU & yes & -0.198 & yes & -0.216 & & & & & no & -0.070 & yes & -0.181 \\
\hline & & & $(-2.759)$ & & $(-1.392)$ & & & & & & $(-1.959)$ & & $(-1.696)$ \\
\hline & EMU & no & -0.036 & no & -0.061 & & & & & yes & -0.265 & no & -0.024 \\
\hline & & & $(-0.352)$ & & $(-1.187)$ & & & & & & $(-1.484)$ & & $(-0.427)$ \\
\hline & postbreak & no & -0.266 & yes & -0.586 & & & & & & & yes & -0.445 \\
\hline & & & $(-1.945)$ & & $(-3.685)$ & & & & & & & & $(-3.275)$ \\
\hline \multirow[t]{8}{*}{ Portugal } & full & no & -0.071 & yes & -0.052 & yes & -0.384 & no & -0.134 & yes & -0.138 & yes & -0.043 \\
\hline & & & $(-2.838)$ & & $(-1.087)$ & & $(-4.792)$ & & $(-2.434)$ & & $(-3.739)$ & & $(-0.885)$ \\
\hline & pre-EMU & no & -0.074 & no & -0.063 & yes & -0.309 & no & -0.08 & yes & -0.717 & yes & -0.178 \\
\hline & & & $(-2.272)$ & & $(-0.991)$ & & $(-2.948)$ & & $(-1.072)$ & & $(-5.032)$ & & $(-1.893)$ \\
\hline & EMU & no & -0.273 & yes & -0.033 & yes & -0.767 & yes & -0.443 & yes & -0.434 & no & -0.066 \\
\hline & & & $(-4.391)$ & & $(-0.398)$ & & $(-4.992)$ & & $(-2.781)$ & & $(-3.530)$ & & $(-0.872)$ \\
\hline & postbreak & & & & & & & & & yes & -0.660 & & \\
\hline & & & & & & & & & & & $(-3.443)$ & & \\
\hline
\end{tabular}


Table 3 continued: Cointegration of Lending Rates

\begin{tabular}{|c|c|c|c|c|c|c|c|c|c|c|c|c|c|}
\hline \multirow[b]{3}{*}{ Country } & \multirow[b]{3}{*}{ Period } & \multicolumn{4}{|c|}{ Mortgage Lending Rates } & \multicolumn{4}{|c|}{ Consumer Lending Rates } & \multicolumn{4}{|c|}{ Corporate Lending Rates } \\
\hline & & \multicolumn{2}{|c|}{ nom } & \multicolumn{2}{|c|}{ real } & \multicolumn{2}{|c|}{ nom } & \multicolumn{2}{|c|}{ real } & \multicolumn{2}{|c|}{ nom } & \multicolumn{2}{|c|}{ real } \\
\hline & & coint? & $\begin{array}{c}\beta_{\mathrm{ECT}} \\
(\mathrm{t}-\mathrm{stat})\end{array}$ & coint? & $\begin{array}{c}\beta_{\mathrm{ECT}} \\
\text { (t-stat) }\end{array}$ & coint? & $\begin{array}{c}\beta_{\mathrm{ECT}} \\
(\mathrm{t}-\mathrm{stat})\end{array}$ & coint? & $\begin{array}{c}\beta_{\mathrm{ECT}} \\
\text { (t-stat) }\end{array}$ & coint? & $\begin{array}{c}\beta_{\mathrm{ECT}} \\
\text { (t-stat) }\end{array}$ & coint? & $\begin{array}{c}\beta_{\mathrm{ECT}} \\
(\mathrm{t}-\mathrm{stat})\end{array}$ \\
\hline \multirow[t]{8}{*}{ Spain } & full & no & -0.035 & no & -0.12 & yes & -0.285 & yes & -0.111 & no & -0.058 & yes & -0.229 \\
\hline & & & $(-1.940)$ & & $(-2.545)$ & & $(-4.226)$ & & $(-2.096)$ & & $(-0.920)$ & & $(-3.269)$ \\
\hline & pre-EMU & no & -0.065 & no & -0.141 & no & -0.338 & no & -0.173 & no & -0.201 & yes & -0.241 \\
\hline & & & $(-2.439)$ & & $(-1.967)$ & & $(-5.702)$ & & $(-2.462)$ & & $(-2.317)$ & & $(-3.064)$ \\
\hline & EMU & no & -0.21 & yes & -0.296 & yes & -0.517 & yes & -0.434 & yes & -0.531 & yes & -0.393 \\
\hline & & & $(-5.106)$ & & $(-3.016)$ & & $(-3.226)$ & & $(-3.817)$ & & $(-2.559)$ & & $(-2.753)$ \\
\hline & postbreak & & & yes & -0.321 & yes & -0.803 & & & & & & \\
\hline & & & & & $(-1.488)$ & & $(-4.528)$ & & & & & & \\
\hline \multirow[t]{8}{*}{ Sweden } & full & no & -0.162 & no & -0.073 & no & -0.086 & no & -0.153 & no & -0.046 & no & -0.059 \\
\hline & & & $(-2.297)$ & & $(-1.558)$ & & $(-2.119)$ & & $(-2.728)$ & & $(-1.981)$ & & $(-1.200)$ \\
\hline & pre-EMU & yes & -0.322 & no & -0.078 & no & -0.152 & no & -0.2 & no & -0.131 & no & -0.098 \\
\hline & & & $(-1.961)$ & & $(-1.340)$ & & $(-2.310)$ & & $(-2.157)$ & & $(-3.138)$ & & $(-1.416)$ \\
\hline & EMU & no & -0.313 & yes & 0.045 & yes & -0.267 & no & 0.06 & yes & -0.185 & no & 0.314 \\
\hline & & & $(-2.632)$ & & $(0.299)$ & & $(-2.740)$ & & -0.622 & & $(-1.257)$ & & (2.439) \\
\hline & postbreak & yes & -0.228 & & & & & & & yes & -0.162 & & \\
\hline & & & $(-1.701)$ & & & & & & & & $(-1.003)$ & & \\
\hline \multirow[t]{8}{*}{ UK } & full & no & -0.074 & no & -0.082 & no & -0.143 & yes & -0.241 & & & & \\
\hline & & & $(-1.925)$ & & $(-1.585)$ & & $(-3.468)$ & & $(-3.404)$ & & & & \\
\hline & pre-EMU & no & -0.21 & no & -0.159 & yes & -0.203 & yes & -0.396 & & & & \\
\hline & & & $(-2.871)$ & & $(-1.835)$ & & $(-2.387)$ & & $(-3.611)$ & & & & \\
\hline & EMU & no & -0.048 & no & -0.106 & yes & -0.356 & yes & -0.465 & & & & \\
\hline & & & $(-0.600)$ & & $(-1.557)$ & & $(-3.086)$ & & $(-3.423)$ & & & & \\
\hline & postbreak & yes & -0.490 & yes & -0.091 & & & & & & & & \\
\hline & & & $(-3.284)$ & & $(-0.671)$ & & & & & & & & \\
\hline
\end{tabular}

Note: Cointegration is considered to exist if at least 2 test statistics of Table A3 are significant at the $10 \%$ level or if at least 1 test statistic is significant at $5 \%$ level or higher. 
cointegration based on best TAR Engle-Granger cointegration selected coint. test: asymmetry tests

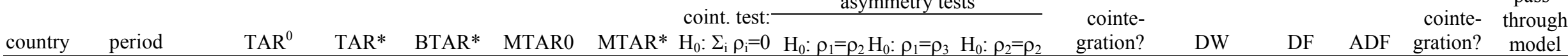
Panel A: Mortgage Lending Rates

\begin{tabular}{|c|c|c|c|c|c|c|c|c|c|c|c|c|c|c|c|c|}
\hline Austria & full & -18.712 & -19.210 & -20.205 & -15.426 & -19.260 & 4.262 & 3.431 & 3.682 & 4.055 & no & 0.023 & -2.260 & & no & STD \\
\hline Austria & pre-EMU & 18.091 & 14.324 & 11.666 & 19.284 & 15.406 & 4.183 & 9.324 & 3.000 & 4.966 & no & 0.195 & -1.276 & & no & STD \\
\hline Austria & EMU & -41.364 & -42.298 & -41.449 & -42.161 & -43.745 & 3.144 & 1.545 & & & no & 0.471 & -2.573 & & yes & SYM \\
\hline Belgium & full & 92.202 & 90.875 & 82.901 & 90.789 & 85.735 & 5.492 & 11.358 & 0.008 & 11.380 & no & 0.143 & -2.018 & & no & STD \\
\hline Belgium & pre-EMU & 38.830 & 36.056 & 33.647 & 38.097 & 32.660 & 3.429 & 5.579 & & & no & 0.156 & -1.074 & & no & STD \\
\hline Belgium & EMU & -6.780 & -8.664 & $\mathbf{- 1 0 . 3 3 7}$ & -8.065 & -9.311 & 4.686 & 4.645 & 0.522 & 5.344 & no & 0.219 & -1.982 & -2.736 & no & STD \\
\hline Finland & full & 28.723 & 26.298 & 26.116 & 28.415 & 22.683 & 3.403 & 5.813 & & & no & 0.044 & -0.895 & & no & STD \\
\hline Finland & pre-EMU & -15.419 & -15.880 & -35.379 & -14.563 & -18.739 & 9.707 & 26.536 & 2.588 & 26.420 & yes & 0.098 & -0.196 & & no & BTAR* \\
\hline Finland & EMU & -23.571 & -26.107 & -24.719 & -21.695 & -24.720 & 5.915 & 4.013 & & & no & 0.598 & -2.691 & & yes & SYM \\
\hline France & full & 67.725 & 66.596 & 62.406 & 67.622 & 48.170 & 10.792 & 20.781 & & & yes, asym & 0.037 & -0.607 & -0.965 & no & MTAR* \\
\hline France & pre-EMU & 15.998 & 15.389 & 14.995 & 16.838 & 4.885 & 6.184 & 12.064 & & & yes, asym & 0.073 & -0.254 & -0.765 & no & MTAR* \\
\hline France & EMU & -24.463 & -26.761 & -26.292 & -25.912 & -26.939 & 10.090 & 2.365 & & & yes, asym & 1.136 & -3.866 & -4.432 & yes & MTAR* \\
\hline Germany & full & 31.653 & 31.142 & 30.166 & 32.298 & 26.782 & 5.196 & 5.376 & & & no & 0.067 & -2.271 & -2.172 & no & STD \\
\hline Germany & pre-EMU & 4.736 & 3.519 & 3.372 & 5.604 & -4.700 & 5.693 & 10.859 & & & no & 0.107 & -0.335 & & no & STD \\
\hline Germany & EMU & -14.335 & -17.113 & -17.086 & -14.551 & -17.561 & 5.168 & 3.331 & & & no & 0.134 & -1.661 & -2.565 & no & STD \\
\hline Greece & EMU & 67.819 & 66.050 & 66.419 & 67.555 & 66.716 & 1.697 & 1.894 & & & no & 0.207 & -1.498 & & no & STD \\
\hline Ireland & full & 126.441 & 124.099 & 124.119 & 125.856 & 124.344 & 4.348 & 2.285 & & & no & 0.215 & -2.162 & & no & STD \\
\hline Ireland & pre-EMU & 4.796 & 0.401 & -7.876 & 5.574 & -4.633 & 8.474 & 13.848 & 0.057 & 9.667 & yes, asym & 0.321 & -2.293 & & no & BTAR* \\
\hline Ireland & EMU & 25.097 & 24.007 & 25.222 & 20.236 & 20.236 & 5.299 & 5.915 & & & no & 0.209 & -1.790 & -2.197 & no & STD \\
\hline Italy & full & 151.658 & 150.551 & 149.721 & 151.593 & 149.349 & 2.581 & 2.166 & & & no & 0.230 & -3.010 & & no & STD \\
\hline Italy & pre-EMU & 60.029 & 55.139 & 52.176 & 59.219 & 58.592 & 3.628 & 6.553 & 0.799 & 8.862 & no & 0.324 & -2.706 & & no & STD \\
\hline Italy & EMU & 0.142 & -1.241 & -3.613 & 0.302 & -3.439 & 3.957 & 4.649 & 0.134 & 5.716 & no & 0.411 & -2.346 & & yes & SYM \\
\hline Netherlands & full & 51.182 & 50.242 & 51.009 & 50.374 & 47.957 & 4.585 & 3.398 & & & no & 0.075 & -2.825 & -2.368 & no & STD \\
\hline Netherlands & pre-EMU & 31.289 & 30.688 & 30.772 & 29.516 & 24.529 & 3.716 & 5.580 & & & no & 0.196 & -1.519 & & no & STD \\
\hline Netherlands & EMU & -12.316 & -13.140 & -19.967 & -12.641 & -16.279 & 5.055 & 10.102 & 0.281 & 9.767 & no & 0.179 & -1.271 & -2.019 & no & STD \\
\hline Portugal & full & 127.514 & 126.374 & 126.521 & 125.083 & 122.139 & 4.809 & 5.162 & & & no & 0.153 & -2.135 & -2.171 & no & STD \\
\hline Portugal & pre-EMU & 29.632 & 27.846 & 27.266 & 29.520 & 24.414 & 5.031 & 4.743 & & & no & 0.166 & -1.866 & -2.042 & no & STD \\
\hline Portugal & EMU & -0.674 & -0.916 & 0.225 & -0.542 & -2.885 & 4.973 & 2.639 & & & no & 0.490 & -2.852 & & yes & SYM \\
\hline Spain & full & 107.891 & 106.126 & 105.209 & 107.788 & 102.890 & 7.853 & 4.931 & & & yes, asym & 0.487 & -3.931 & & yes & MTAR* \\
\hline Spain & pre-EMU & 45.312 & 43.086 & 40.946 & 45.256 & 43.206 & 5.152 & 5.458 & 0.574 & 6.158 & no & 0.785 & -3.209 & & yes & SYM \\
\hline Spain & EMU & -22.087 & -22.242 & -25.697 & -22.905 & -23.730 & 4.563 & 5.009 & 0.040 & 5.160 & no & 0.592 & -2.701 & -3.541 & yes & SYM \\
\hline Sweden & full & 79.638 & 76.305 & 72.303 & 79.886 & 77.787 & 5.421 & 8.952 & 0.558 & 9.110 & yes, asym & 0.157 & -1.877 & -2.404 & no & BTAR* \\
\hline Sweden & pre-EMU & 29.257 & 26.531 & 23.244 & 29.047 & 26.067 & 3.520 & 7.399 & 0.401 & 7.404 & no & 0.148 & -1.421 & -1.610 & no & STD \\
\hline Sweden & EMU & -1.257 & -3.321 & -2.033 & 1.186 & -0.542 & 6.709 & 4.285 & & & no & 0.188 & -1.855 & -2.578 & no & STD \\
\hline
\end{tabular}


Table 4 continued: Pass-Through Model Selection

\begin{tabular}{|c|c|c|c|c|c|c|c|c|c|c|c|c|c|c|c|c|}
\hline \multirow[b]{2}{*}{ country } & \multirow[b]{2}{*}{ period } & \multicolumn{5}{|c|}{ AIC values at optimal lag length } & \multicolumn{5}{|c|}{ cointegration based on best TAR } & \multicolumn{4}{|c|}{ Engle-Granger cointegration } & \multirow{2}{*}{$\begin{array}{c}\text { selected } \\
\text { pass- } \\
\text { through } \\
\text { model } \\
\end{array}$} \\
\hline & & $\mathrm{TAR}^{0}$ & TAR* & BTAR* & MTAR $^{0}$ & MTAR* & $\begin{array}{l}\text { coint. test: } \\
\mathrm{H}_{0}: \sum_{\mathrm{i}} \rho_{\mathrm{i}}=0 \\
\end{array}$ & $\mathrm{H}_{0}: \rho_{1}=\rho_{2} \mathrm{H}_{0}$ : & $\rho_{1}=\rho_{3}$ & $\mathrm{H}_{0}: \rho_{2}=\rho_{2}$ & $\begin{array}{l}\text { cointe- } \\
\text { gration? }\end{array}$ & DW & $\mathrm{DF}$ & $\mathrm{ADF}$ & $\begin{array}{l}\text { cointe- } \\
\text { gration? }\end{array}$ & \\
\hline UK & full & 141.913 & 135.889 & 129.941 & 141.772 & 131.902 & 6.410 & 6.660 & 1.157 & 12.758 & yes,asym & 0.136 & -3.138 & -2.124 & no & BTAR* \\
\hline UK & pre-EMU & 45.663 & 44.675 & 44.875 & 45.904 & 43.850 & 3.731 & 6.989 & & & no & 0.251 & -0.553 & -0.553 & no & STD \\
\hline UK & EMU & 23.008 & $\mathbf{1 7 . 5 6 6}$ & 18.252 & 21.929 & 19.927 & 4.996 & 5.618 & & & no & 0.328 & -2.148 & -2.328 & no & STD \\
\hline \multicolumn{17}{|c|}{ Panel B: Consumer Lending Rates } \\
\hline Austria & full & 18.355 & 17.562 & 15.181 & 23.000 & 19.828 & 5.908 & 5.705 & 5.458 & 4.758 & no & 0.022 & -2.501 & & no & STD \\
\hline Austria & pre-EMU & 41.087 & 39.837 & 39.437 & 41.817 & 38.164 & 1.995 & 3.637 & & & no & 0.253 & -1.435 & -1.015 & no & STD \\
\hline Austria & EMU & -47.224 & -47.909 & -46.467 & -45.636 & -47.292 & 6.808 & 1.012 & & & yes, sym. & 0.623 & -3.550 & -3.241 & yes & SYM \\
\hline Belgium & full & 181.190 & 180.592 & 180.262 & 177.819 & 148.008 & 28.493 & 43.942 & & & yes, asym & 0.098 & -2.533 & & no & MTAR* \\
\hline Belgium & pre-EMU & 89.256 & 87.285 & 86.167 & 89.959 & 82.737 & 3.931 & 6.999 & & & no & 0.248 & -1.629 & & no & STD \\
\hline Belgium & EMU & 1.030 & -0.588 & -3.609 & 0.059 & -3.147 & 4.051 & 6.681 & 0.049 & 6.675 & no & 0.322 & -2.197 & & no & STD \\
\hline Denmark & full & 77.845 & 77.641 & 71.542 & 78.164 & 76.877 & 4.417 & 0.686 & 5.326 & 9.038 & no & 0.214 & -2.184 & -1.955 & no & STD \\
\hline Denmark & pre-EMU & 0.520 & -1.276 & -4.726 & 0.597 & -0.550 & 3.185 & 6.833 & 0.201 & 6.912 & no & 0.379 & -1.918 & & no & STD \\
\hline Denmark & EMU & 12.653 & 11.270 & 10.230 & 10.082 & 7.516 & 8.609 & 5.330 & & & yes, asym & 0.933 & -3.375 & -3.327 & yes & MTAR* \\
\hline Finland & full & 129.889 & 128.861 & 128.399 & 127.865 & 119.506 & 6.033 & 11.433 & & & yes, asym & 0.192 & -2.075 & -0.741 & no & MTAR* \\
\hline Finland & pre-EMU & 59.790 & 54.981 & 55.216 & 58.911 & 49.056 & 6.008 & 12.008 & & & yes, asym & 0.617 & -2.438 & -0.659 & yes & MTAR* \\
\hline Finland & EMU & -11.992 & -13.650 & -11.693 & -12.367 & -19.790 & 8.817 & 8.729 & & & yes, asym & 0.691 & -2.932 & & yes & MTAR* \\
\hline France & full & 95.562 & 93.824 & 94.703 & 93.159 & 77.991 & 9.990 & 18.785 & & & yes, asym & 0.040 & -0.692 & -0.974 & no & MTAR* \\
\hline France & pre-EMU & 40.386 & 39.082 & 38.453 & 42.472 & 31.068 & 5.775 & 11.461 & & & no & 0.110 & -0.522 & & no & STD \\
\hline France & EMU & -40.027 & -40.775 & -40.317 & -41.478 & -42.064 & 4.734 & 3.108 & & & no & 0.588 & -2.432 & & yes & SYM \\
\hline Germany & full & -62.051 & -62.442 & -65.429 & -56.973 & -61.289 & 6.727 & 6.122 & 5.683 & 4.815 & yes, asym & 0.012 & -3.398 & -2.597 & yes & BTAR* \\
\hline Germany & pre-EMU & 6.206 & 3.030 & 1.929 & 3.259 & 1.225 & 2.737 & 4.935 & & & no & 0.095 & -0.736 & & no & STD \\
\hline Germany & EMU & -83.435 & -85.331 & -93.187 & -83.207 & -83.471 & 4.365 & 6.415 & 0.643 & 10.550 & no & 0.072 & -0.196 & -1.449 & no & STD \\
\hline Greece & EMU & 143.923 & 142.346 & 136.516 & 144.682 & 143.855 & 4.191 & 8.633 & 1.748 & 7.020 & no & 0.151 & -1.088 & & no & STD \\
\hline Portugal & full & 314.500 & 311.923 & 314.725 & 314.472 & 311.146 & 4.886 & 3.235 & & & no & 0.671 & -4.119 & -4.119 & yes & SYM \\
\hline Portugal & pre-EMU & 139.137 & 137.954 & 136.794 & 139.043 & 138.572 & 3.047 & 3.697 & 0.001 & 3.774 & no & 0.966 & -3.933 & & yes & SYM \\
\hline Portugal & EMU & 93.467 & 92.779 & 89.893 & 92.907 & 91.914 & 2.615 & 4.488 & 0.137 & 4.829 & no & 1.187 & -4.017 & -2.229 & yes & SYM \\
\hline Spain & full & 176.654 & 174.535 & 169.552 & 177.281 & 174.567 & 5.017 & 8.797 & 0.857 & 8.754 & no & 0.473 & -3.342 & & yes & SYM \\
\hline Spain & pre-EMU & 53.491 & 50.555 & 47.809 & 53.359 & 49.841 & 3.462 & 4.158 & 0.701 & 6.717 & no & 0.583 & -2.722 & & yes & SYM \\
\hline Spain & EMU & 37.273 & 32.493 & 28.699 & 36.340 & 29.755 & 9.674 & 10.288 & 1.985 & 10.194 & yes, asym & 1.211 & -4.447 & -4.306 & yes & BTAR* \\
\hline Sweden & full & 28.713 & 26.861 & 21.840 & 29.446 & 26.492 & 3.110 & 6.629 & 1.326 & 9.075 & no & 0.236 & -1.750 & -1.669 & no & STD \\
\hline Sweden & pre-EMU & -3.373 & -4.422 & -5.973 & -5.217 & -5.445 & 1.352 & 3.840 & 0.174 & 3.992 & no & 0.735 & -2.821 & -2.438 & yes & SYM \\
\hline Sweden & EMU & -44.830 & -46.750 & -47.121 & -45.355 & -47.110 & 2.496 & 3.677 & 0.007 & 3.668 & no & 0.604 & -2.266 & -2.331 & yes & SYM \\
\hline UK & full & 263.209 & 262.471 & 252.506 & 262.793 & 252.449 & 7.298 & 10.789 & & & yes, asym & 0.221 & -2.640 & -2.087 & no & MTAR* \\
\hline UK & pre-EMU & 64.861 & 64.549 & 62.909 & 64.998 & $\mathbf{5 9 . 1 0 7}$ & 4.949 & 5.575 & & & no & 0.135 & -0.960 & & no & STD \\
\hline UK & EMU & 36.254 & 28.249 & 33.296 & 36.184 & 26.370 & 7.403 & 9.472 & & & yes, asym & 0.700 & -3.333 & & yes & MTAR* \\
\hline
\end{tabular}


Table 4 continued: Pass-Through Model Selection

AIC values at optimal lag length

cointegration based on best TAR Engle-Granger cointegration selected

coint test: asymmetry tests

cointe- through TAR $^{0} \quad$ TAR $^{*} \quad$ BTAR MTAR0 MTAR $^{*} \mathrm{H}_{0}: \Sigma_{\mathrm{i}} \rho_{\mathrm{i}}=0 \quad \mathrm{H}_{0}: \rho_{1}=\rho_{2} \mathrm{H}_{0}: \rho_{1}=\rho_{3} \quad \mathrm{H}_{0}: \rho_{2}=\rho_{2} \quad$ gration?

Panel C: Corporate Lending Rates

\begin{tabular}{|c|c|c|c|c|c|c|c|c|c|c|c|c|c|c|c|c|}
\hline Austria & full & -43.629 & -43.815 & -43.668 & -38.839 & -40.806 & 5.381 & 7.297 & & & no & 0.016 & -2.109 & -1.811 & no & STD \\
\hline Austria & pre-EMU & 16.502 & 11.820 & 9.505 & 17.367 & 12.852 & 4.173 & 10.043 & 3.628 & 4.225 & no & 0.156 & -1.017 & & no & STD \\
\hline Austria & EMU & -55.898 & -56.726 & -60.344 & -57.053 & -57.116 & 5.327 & 6.911 & 0.198 & 6.284 & no & 0.451 & -2.832 & & yes & SYM \\
\hline Belgium & full & 10.386 & 9.210 & 8.752 & 8.745 & 4.573 & 9.281 & 6.161 & & & yes, asym & 0.688 & -4.368 & & yes & MTAR* \\
\hline Belgium & pre-EMU & -31.691 & -33.068 & -33.352 & -35.647 & -36.521 & 4.024 & 5.435 & & & no & 1.255 & -4.621 & & yes & SYM \\
\hline Belgium & EMU & -14.187 & -16.008 & -16.872 & -13.939 & -20.421 & 6.881 & 6.941 & & & yes, asym & 0.486 & -2.495 & & yes & MTAR* \\
\hline Denmark & full & 75.773 & 71.279 & 61.092 & 74.096 & 70.924 & 8.158 & 9.208 & 3.455 & 16.700 & yes, asym & 0.190 & -2.227 & -2.382 & no & MTAR* \\
\hline Denmark & pre-EMU & 27.854 & 26.667 & 23.532 & 25.305 & 22.525 & 4.027 & 5.627 & & & no & 0.197 & -1.378 & & no & STD \\
\hline Denmark & EMU & 10.677 & 3.047 & 0.780 & 11.818 & 9.250 & 4.714 & 3.865 & 3.558 & 14.109 & no & 0.458 & -1.825 & -2.017 & yes & SYM \\
\hline France & full & 109.413 & 106.616 & 103.113 & 109.322 & 99.124 & 6.189 & 10.159 & & & yes, asym & 0.062 & -1.006 & -1.564 & no & MTAR* \\
\hline France & pre-EMU & 29.103 & 26.211 & 28.152 & 29.561 & 22.722 & 4.215 & 6.538 & & & no & 0.070 & -0.434 & -1.330 & no & STD \\
\hline France & EMU & 9.182 & 7.837 & 7.814 & 9.209 & 6.966 & 7.758 & 2.119 & & & yes, asym & 1.058 & -3.660 & -3.896 & yes & MTAR* \\
\hline Germany & full & -3.503 & -7.066 & -5.090 & -4.249 & -6.387 & 2.954 & 4.580 & & & no & 0.189 & -1.420 & & no & STD \\
\hline Germany & pre-EMU & -41.853 & -42.221 & -43.540 & -40.799 & -45.274 & 2.868 & 4.404 & & & no & 0.308 & -2.004 & & no & STD \\
\hline Germany & EMU & -25.039 & -27.459 & -30.691 & -22.690 & -23.851 & 3.520 & 5.531 & 2.496 & 9.168 & no & 0.144 & -0.709 & & no & STD \\
\hline Greece & EMU & 127.066 & 126.389 & 116.923 & 128.460 & 127.107 & 4.979 & 11.615 & 1.938 & 10.853 & no & 0.166 & -1.067 & & no & STD \\
\hline Ireland & full & 50.256 & 46.498 & 40.883 & 50.066 & 45.023 & 6.163 & 7.946 & 1.289 & 11.089 & no & 0.389 & -2.981 & -2.024 & yes & SYM \\
\hline Ireland & pre-EMU & 10.077 & 9.489 & 1.463 & 10.273 & 7.986 & 6.635 & 10.080 & 0.003 & 9.401 & no & 0.649 & -2.903 & -1.949 & yes & SYM \\
\hline Ireland & EMU & -13.299 & -17.056 & -18.059 & -12.070 & -14.573 & 4.054 & 6.624 & 1.276 & 6.810 & no & 0.358 & -1.892 & & no & STD \\
\hline Italy & full & 98.323 & 97.699 & 87.826 & 94.209 & 91.515 & 5.107 & 12.339 & 0.001 & 12.353 & no & 0.176 & -2.770 & & no & STD \\
\hline Italy & pre-EMU & 25.615 & 21.013 & 21.372 & 22.912 & 19.594 & 4.654 & 7.192 & & & no & 0.282 & -2.814 & & no & STD \\
\hline Italy & EMU & -31.809 & -33.647 & -37.445 & -30.788 & -36.023 & 5.623 & 8.890 & 0.840 & 5.771 & no & 0.202 & -2.584 & & no & STD \\
\hline Netherlands & full & 88.105 & 87.430 & 87.422 & 88.399 & 85.417 & 4.663 & 2.893 & & & no & 0.821 & -4.339 & & yes & SYM \\
\hline Netherlands & pre-EMU & -1.091 & -3.667 & -4.690 & 0.071 & -1.603 & 2.262 & 4.233 & 1.698 & 5.967 & no & 0.862 & -2.657 & -0.716 & yes & SYM \\
\hline Netherlands & EMU & 25.902 & 24.803 & 24.342 & 25.282 & 24.536 & 3.596 & 3.442 & 0.158 & 3.440 & no & 0.807 & -2.626 & & yes & SYM \\
\hline Portugal & full & 196.386 & 192.398 & 191.121 & 196.795 & 190.441 & 5.042 & 6.744 & & & no & 0.377 & -2.928 & -2.387 & no & STD \\
\hline Portugal & pre-EMU & 73.258 & 69.654 & 65.301 & 73.607 & 73.152 & 8.890 & 9.303 & 0.861 & 9.327 & yes, asym & 1.556 & -5.232 & -5.331 & yes & BTAR* \\
\hline Portugal & EMU & 13.385 & 12.177 & 11.384 & 14.338 & 9.858 & 8.404 & 4.707 & & & yes, asym & 0.616 & -3.395 & & yes & MTAR* \\
\hline
\end{tabular}


Table 4 continued: Pass-Through Model Selection

AIC values at optimal lag length

cointegration based on best TAR

Engle-Granger cointegration

selected

coint. test: asymmetry test

\begin{tabular}{|c|c|c|c|c|c|c|c|c|c|c|c|c|c|c|c|c|}
\hline \multirow[b]{3}{*}{ country } & \multirow[b]{3}{*}{ period } & \multirow{2}{*}{\multicolumn{5}{|c|}{$\mathrm{C}_{\mathrm{C}} \mathrm{C}$}} & \multirow{2}{*}{\multicolumn{4}{|c|}{ ametry tests }} & \multicolumn{5}{|c|}{0} & \multirow{3}{*}{$\begin{array}{c}\text { pass- } \\
\text { through } \\
\text { model }\end{array}$} \\
\hline & & & & & & & & & & & & & & & & \\
\hline & & $\mathrm{TAR}^{0}$ & TAR* & BTAR* & MTAR $^{0}$ & MTAR* & $\mathrm{H}_{0}: \Sigma_{\mathrm{i}} \rho_{\mathrm{i}}=0$ & $\mathrm{H}_{0}: \rho_{1}=\rho_{2} \mathrm{H}_{0}$ & $: \rho_{1}=\rho_{3}$ & $H_{0}: \rho_{2}=\rho_{2}$ & gration? & DW & DF & $\mathrm{ADF}$ & gration? & \\
\hline Spain & full & 116.671 & 114.864 & 116.380 & 116.906 & 116.403 & 4.047 & 2.994 & & & no & 0.965 & -5.371 & -3.348 & yes & SYM \\
\hline Spain & pre-EMU & 33.687 & 31.000 & 30.419 & 34.317 & 29.487 & 2.444 & 4.424 & & & no & 0.800 & -2.799 & & yes & SYM \\
\hline Spain & EMU & 12.731 & 12.443 & 10.750 & 12.718 & 11.268 & 5.104 & 3.307 & 0.075 & 3.426 & no & 1.499 & -4.771 & & yes & SYM \\
\hline Sweden & full & 57.601 & 52.644 & 54.189 & 57.477 & 52.872 & 3.219 & 4.716 & & & no & 0.332 & -2.644 & -2.313 & no & STD \\
\hline Sweden & pre-EMU & 14.202 & 8.051 & 7.167 & 10.970 & 9.506 & 4.165 & 3.447 & 0.703 & 8.686 & no & 0.551 & -2.914 & -2.451 & yes & SYM \\
\hline Sweden & EMU & -42.618 & -42.944 & -43.385 & -41.800 & -43.486 & 6.207 & 2.180 & & & yes, asym & 0.870 & -3.233 & & yes & MTAR* \\
\hline
\end{tabular}

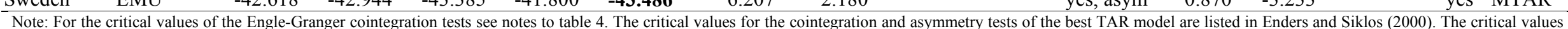

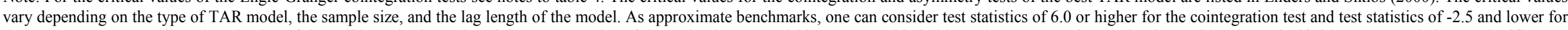

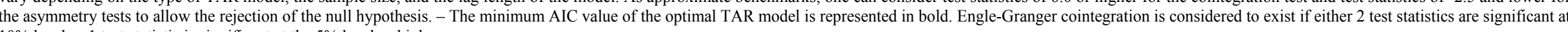
$10 \%$ level or 1 test statistic is significant at the $5 \%$ level or higher. 
Table 5: Extended Pass-Through of Money Market Rate Innovations onto Lending Rates in Europe

\begin{tabular}{|c|c|c|c|c|c|c|c|c|c|c|}
\hline \multirow[t]{2}{*}{ Country } & \multirow[t]{2}{*}{ Period } & \multirow[t]{2}{*}{ Model } & \multirow{2}{*}{$\begin{array}{c}\text { Impact } \\
\text { Multiplier } \\
\beta_{2}\end{array}$} & \multirow{2}{*}{$\begin{array}{c}\text { Long-run } \\
\text { Multiplier } \\
\theta\end{array}$} & \multicolumn{3}{|c|}{$\begin{array}{c}\text { Error Correction } \\
\text { Speed of Adjustment }\end{array}$} & \multirow{2}{*}{$\begin{array}{c}\text { Optimal } \\
\text { Threshold } \\
a_{0} *\end{array}$} & \multicolumn{2}{|c|}{ Lags } \\
\hline & & & & & $\beta_{\mathrm{ECT}, 1}$ & $\beta_{\mathrm{ECT}, 2}$ & $\beta_{\mathrm{ECT}, 3}$ & & $\mathrm{k}^{*}$ & $\mathrm{n}^{*}$ \\
\hline \multicolumn{11}{|c|}{ Panel A: Mortgage Lending Rates } \\
\hline \multirow[t]{3}{*}{ Austria } & full & STD & $\begin{array}{c}0.136 \\
(2.597)\end{array}$ & 0.653 & & & & & 4 & 1 \\
\hline & pre & STD & $\begin{array}{c}0.064 \\
(0.752)\end{array}$ & 0.563 & & & & & 4 & 1 \\
\hline & EMU & SYM & $\begin{array}{c}0.158 \\
(3.256)\end{array}$ & 0.590 & $\begin{array}{l}-0.423 \\
(-5.550)\end{array}$ & & & & 3 & 0 \\
\hline \multirow[t]{3}{*}{ Belgium } & full & STD & $\begin{array}{c}0.282 \\
(3.053)\end{array}$ & 0.641 & & & & & 2 & 1 \\
\hline & pre & STD & $\begin{array}{c}0.240 \\
(1.721)\end{array}$ & 0.712 & & & & & 2 & 1 \\
\hline & EMU & STD & $\begin{array}{c}0.356 \\
(2.919)\end{array}$ & 0.413 & & & & & 0 & 1 \\
\hline \multirow[t]{3}{*}{ Finland } & full & STD & $\begin{array}{c}0.374 \\
(5.826)\end{array}$ & 0.749 & & & & & 1 & 1 \\
\hline & pre & BTAR* & $\begin{array}{c}0.304 \\
(3.510)\end{array}$ & 1.032 & $\begin{array}{c}-0.082 \\
(-0.960)\end{array}$ & $\begin{array}{c}-10.617 \\
(-0.858)\end{array}$ & $\begin{array}{c}0.057 \\
(0.908)\end{array}$ & 0.009 & 1 & 1 \\
\hline & EMU & SYM & $\begin{array}{c}0.475 \\
(4.607)\end{array}$ & 0.832 & $\begin{array}{l}-0.216 \\
(-1.869)\end{array}$ & & & & 1 & 1 \\
\hline \multirow[t]{3}{*}{ France } & full & MTAR* & $\begin{array}{c}0.134 \\
(2.221)\end{array}$ & 0.611 & $\begin{array}{c}0.003 \\
(0.041)\end{array}$ & $\begin{array}{l}-0.028 \\
(-1.741)\end{array}$ & & 0.275 & 3 & 0 \\
\hline & pre & MTAR* & $\begin{array}{c}-0.080 \\
(-1.044)\end{array}$ & 0.545 & $\begin{array}{c}0.104 \\
(0.748)\end{array}$ & $\begin{array}{c}-0.024 \\
(-0.954)\end{array}$ & & 0.246 & 4 & 0 \\
\hline & EMU & MTAR* & $\begin{array}{c}0.391 \\
(4.039)\end{array}$ & 0.515 & $\begin{array}{l}-0.530 \\
(-1.963)\end{array}$ & $\begin{array}{l}-0.812 \\
(-4.171)\end{array}$ & & 0.053 & 3 & 0 \\
\hline \multirow[t]{3}{*}{ Germany } & full & STD & $\begin{array}{c}0.483 \\
(4.348)\end{array}$ & 0.185 & & & & & 4 & 2 \\
\hline & pre & STD & $\begin{array}{c}0.325 \\
(1.824)\end{array}$ & 0.405 & & & & & 0 & 2 \\
\hline & EMU & STD & $\begin{array}{c}0.584 \\
(4.229)\end{array}$ & 0.145 & & & & & 4 & 2 \\
\hline Greece & EMU & STD & $\begin{array}{c}-0.001 \\
(-0.044)\end{array}$ & -0.001 & & & & & 0 & 4 \\
\hline \multirow[t]{3}{*}{ Ireland } & full & STD & $\begin{array}{c}0.239 \\
(3.549)\end{array}$ & 0.589 & & & & & 1 & 1 \\
\hline & pre & BTAR* & $\begin{array}{c}0.205 \\
(3.809)\end{array}$ & 0.492 & $\begin{array}{l}-0.081 \\
(-0.781)\end{array}$ & $\begin{array}{l}-0.228 \\
(-1.797)\end{array}$ & $\begin{array}{c}-0.251 \\
(-1.555)\end{array}$ & 0.359 & 3 & 1 \\
\hline & EMU & STD & $\begin{array}{c}0.235 \\
(1.120)\end{array}$ & 0.870 & & & & & 1 & 1 \\
\hline \multirow[t]{3}{*}{ Italy } & full & STD & $\begin{array}{c}0.286 \\
(2.695)\end{array}$ & 0.694 & & & & & 2 & 3 \\
\hline & pre & STD & $\begin{array}{c}0.257 \\
(1.632)\end{array}$ & 0.783 & & & & & 2 & 3 \\
\hline & EMU & SYM & $\begin{array}{c}0.179 \\
(1.258)\end{array}$ & 0.552 & $\begin{array}{l}-0.596 \\
(-4.037)\end{array}$ & & & & 1 & 2 \\
\hline \multirow[t]{3}{*}{ Netherlands } & full & STD & $\begin{array}{c}0.142 \\
(1.767)\end{array}$ & 0.459 & & & & & 1 & 1 \\
\hline & pre & STD & $\begin{array}{c}0.071 \\
(0.577)\end{array}$ & 0.092 & & & & & 0 & 1 \\
\hline & EMU & STD & $\begin{array}{c}0.152 \\
(1.431)\end{array}$ & 0.315 & & & & & 0 & 1 \\
\hline \multirow[t]{3}{*}{ Portugal } & full & STD & $\begin{array}{c}0.212 \\
(2.764)\end{array}$ & 0.926 & & & & & 2 & 4 \\
\hline & pre & STD & $\begin{array}{c}0.174 \\
(1.500)\end{array}$ & 0.468 & & & & & 0 & 4 \\
\hline & EMU & SYM & $\begin{array}{c}0.017 \\
(0.190)\end{array}$ & 0.813 & $\begin{array}{l}-0.180 \\
(-2.339)\end{array}$ & & & & 1 & 1 \\
\hline
\end{tabular}


Table 5 continued: Extented Pass-Through of Money Market Rate Innovations onto Lending Rates in Europe

\begin{tabular}{|c|c|c|c|c|c|c|c|c|c|c|}
\hline \multirow[t]{2}{*}{ Country } & \multirow[t]{2}{*}{ Period } & \multirow[t]{2}{*}{ Model } & \multirow{2}{*}{$\begin{array}{c}\text { Impact } \\
\text { Multiplier } \\
\beta_{2}\end{array}$} & \multirow{2}{*}{$\begin{array}{c}\text { Long-run } \\
\text { Multiplier } \\
\theta\end{array}$} & \multicolumn{3}{|c|}{$\begin{array}{c}\text { Error Correction } \\
\text { Speed of Adjustment }\end{array}$} & \multirow{2}{*}{$\begin{array}{c}\text { Optimal } \\
\text { Threshold } \\
\mathrm{a}_{0} *\end{array}$} & \multicolumn{2}{|c|}{ Lags } \\
\hline & & & & & $\beta_{\mathrm{ECT}, 1}$ & $\beta_{\mathrm{ECT}, 2}$ & $\beta_{\mathrm{ECT}, 3}$ & & $\mathrm{k}^{*}$ & $\mathrm{n}^{*}$ \\
\hline \multirow[t]{3}{*}{ Spain } & full & MTAR* & $\begin{array}{c}0.180 \\
(4.688)\end{array}$ & 1.077 & $\begin{array}{l}-0.043 \\
(-1.316)\end{array}$ & $\begin{array}{c}0.017 \\
(0.159)\end{array}$ & & -0.323 & 1 & 2 \\
\hline & pre & SYM & $\begin{array}{c}0.144 \\
(2.901)\end{array}$ & 1.139 & $\begin{array}{c}-0.047 \\
(-0.879)\end{array}$ & & & & 1 & 2 \\
\hline & EMU & SYM & $\begin{array}{c}0.106 \\
(2.352)\end{array}$ & 0.742 & $\begin{array}{c}-0.345 \\
(-6.768)\end{array}$ & & & & 1 & 0 \\
\hline \multirow[t]{3}{*}{ Sweden } & full & BTAR* & $\begin{array}{c}0.074 \\
(0.376)\end{array}$ & 0.711 & $\begin{array}{c}-0.187 \\
(-1.760)\end{array}$ & $\begin{array}{c}-1.286 \\
(-0.472)\end{array}$ & $\begin{array}{c}0.026 \\
(0.222)\end{array}$ & 0.089 & 3 & 0 \\
\hline & pre & STD & $\begin{array}{c}0.048 \\
(0.176)\end{array}$ & 0.046 & & & & & 0 & 3 \\
\hline & EMU & STD & $\begin{array}{c}-0.024 \\
(-0.075)\end{array}$ & -0.038 & & & & & 0 & 3 \\
\hline \multirow[t]{3}{*}{ UK } & full & BTAR* & $\begin{array}{c}0.054 \\
(1.511)\end{array}$ & 0.441 & $\begin{array}{c}-0.090 \\
(-2.683)\end{array}$ & $\begin{array}{c}0.030 \\
(0.796)\end{array}$ & $\begin{array}{c}-0.135 \\
(-2.538)\end{array}$ & 0.863 & 4 & 1 \\
\hline & pre & STD & $\begin{array}{c}0.037 \\
(0.526)\end{array}$ & -0.443 & & & & & 4 & 4 \\
\hline & EMU & STD & $\begin{array}{c}0.002 \\
(0.053)\end{array}$ & 0.003 & & & & & 0 & 1 \\
\hline \multicolumn{11}{|c|}{ Panel B: Consumer Lending Rates } \\
\hline \multirow[t]{3}{*}{ Austria } & full & STD & $\begin{array}{c}0.143 \\
(2.055)\end{array}$ & 0.750 & & & & & 3 & 4 \\
\hline & pre & STD & $\begin{array}{c}0.049 \\
(0.415)\end{array}$ & 0.908 & & & & & 3 & 3 \\
\hline & EMU & SYM & $\begin{array}{c}0.219 \\
(3.872)\end{array}$ & 0.589 & $\begin{array}{c}-0.431 \\
(-4.432)\end{array}$ & & & & 3 & 4 \\
\hline \multirow[t]{3}{*}{ Belgium } & full & MTAR* & $\begin{array}{c}0.915 \\
(3.900)\end{array}$ & 1.095 & $\begin{array}{c}-0.022 \\
(-0.290)\end{array}$ & $\begin{array}{c}-0.170 \\
(-4.203)\end{array}$ & & 0.097 & 2 & 3 \\
\hline & pre & STD & $\begin{array}{c}0.980 \\
(2.795)\end{array}$ & 1.321 & & & & & 1 & 1 \\
\hline & EMU & STD & $\begin{array}{c}0.488 \\
(3.013)\end{array}$ & 0.369 & & & & & 33 & 1 \\
\hline \multirow[t]{3}{*}{ Denmark } & full & STD & $\begin{array}{c}0.320 \\
(3.275)\end{array}$ & 0.582 & & & & & 3 & 2 \\
\hline & pre & STD & $\begin{array}{c}0.167 \\
(1.523)\end{array}$ & 0.174 & & & & & 0 & 3 \\
\hline & EMU & MTAR* & $\begin{array}{c}0.047 \\
(0.392)\end{array}$ & 0.574 & $\begin{array}{c}-0.472 \\
(-2.760)\end{array}$ & $\begin{array}{c}-0.417 \\
(-1.420)\end{array}$ & & -0.252 & 3 & 1 \\
\hline \multirow[t]{3}{*}{ Finland } & full & MTAR* & $\begin{array}{c}0.640 \\
(3.610)\end{array}$ & 1.027 & $\begin{array}{c}0.381 \\
(1.413)\end{array}$ & $\begin{array}{l}-0.061 \\
(1.507)\end{array}$ & & 0.458 & 2 & 1 \\
\hline & pre & MTAR* & $\begin{array}{c}0.284 \\
(0.762)\end{array}$ & 1.089 & $\begin{array}{c}1.349 \\
(1.852)\end{array}$ & $\begin{array}{c}0.039 \\
(0.358)\end{array}$ & & 0.501 & 2 & 1 \\
\hline & EMU & MTAR* & $\begin{array}{c}0.547 \\
(4.089)\end{array}$ & 0.833 & $\begin{array}{c}-0.482 \\
(-2.601)\end{array}$ & $\begin{array}{c}0.043 \\
(0.146)\end{array}$ & & -0.166 & 1 & 1 \\
\hline \multirow[t]{3}{*}{ France } & full & MTAR* & $\begin{array}{c}-0.063 \\
(-0.934)\end{array}$ & 0.629 & $\begin{array}{c}0.043 \\
(0.653)\end{array}$ & $\begin{array}{c}-0.035 \\
(-2.002)\end{array}$ & & 0.293 & 3 & 4 \\
\hline & pre & STD & $\begin{array}{c}-0.150 \\
(-1.582)\end{array}$ & -0.144 & & & & & 0 & 3 \\
\hline & EMU & SYM & $\begin{array}{c}0.033 \\
(0.483)\end{array}$ & 0.285 & $\begin{array}{c}-0.609 \\
(-4.257)\end{array}$ & & & & 3 & 2 \\
\hline \multirow[t]{3}{*}{ Germany } & full & BTAR* & $\begin{array}{c}0.087 \\
(1.700)\end{array}$ & 0.335 & $\begin{array}{c}-0.038 \\
(-2.144)\end{array}$ & $\begin{array}{c}0.143 \\
(0.630)\end{array}$ & $\begin{array}{c}-0.102 \\
(-3.247)\end{array}$ & 0.153 & 3 & 3 \\
\hline & pre & STD & $\begin{array}{c}0.140 \\
(1.376)\end{array}$ & 0.412 & & & & & 3 & 3 \\
\hline & EMU & STD & $\begin{array}{c}0.116 \\
(2.575)\end{array}$ & 0.282 & & & & & 2 & 1 \\
\hline Greece & EMU & STD & $\begin{array}{c}-0.048 \\
(-0.615)\end{array}$ & -0.084 & & & & & 0 & 4 \\
\hline
\end{tabular}


Table 5 continued: Extented Pass-Through of Money Market Rate Innovations onto Lending Rates in Europe

\begin{tabular}{|c|c|c|c|c|c|c|c|c|c|c|}
\hline \multirow[t]{2}{*}{ Country } & \multirow[t]{2}{*}{ Period } & \multirow[t]{2}{*}{ Model } & \multirow{2}{*}{$\begin{array}{c}\text { Impact } \\
\text { Multiplier } \\
\beta_{2}\end{array}$} & \multirow{2}{*}{$\begin{array}{c}\text { Long-run } \\
\text { Multiplier } \\
\theta\end{array}$} & \multicolumn{3}{|c|}{$\begin{array}{c}\text { Error Correction } \\
\text { Speed of Adjustment }\end{array}$} & \multirow{2}{*}{$\begin{array}{c}\text { Optimal } \\
\text { Threshold } \\
a_{0} *\end{array}$} & \multicolumn{2}{|c|}{ Lags } \\
\hline & & & & & $\beta_{\mathrm{ECT}, 1}$ & $\beta_{\mathrm{ECT}, 2}$ & $\beta_{\mathrm{ECT}, 3}$ & & $\mathrm{k}^{*}$ & $\mathrm{n}^{*}$ \\
\hline \multirow[t]{3}{*}{ Portugal } & full & SYM & $\begin{array}{c}0.210 \\
(0.489)\end{array}$ & 1.566 & $\begin{array}{c}-0.318 \\
(-3.859)\end{array}$ & & & & 1 & 0 \\
\hline & pre & SYM & $\begin{array}{c}0.251 \\
(0.303)\end{array}$ & 1.692 & $\begin{array}{c}-0.542 \\
(-3.845)\end{array}$ & & & & 1 & 0 \\
\hline & EMU & SYM & $\begin{array}{c}-0.696 \\
(-1.583)\end{array}$ & 0.477 & $\begin{array}{l}-0.510 \\
(-3.297)\end{array}$ & & & & 1 & 0 \\
\hline \multirow[t]{3}{*}{ Spain } & full & SYM & $\begin{array}{c}0.743 \\
(5.571)\end{array}$ & 1.215 & $\begin{array}{c}-0.225 \\
(-3.514)\end{array}$ & & & & 4 & 0 \\
\hline & pre & SYM & $\begin{array}{c}0.705 \\
(4.731)\end{array}$ & 1.246 & $\begin{array}{c}-0.264 \\
(-2.766)\end{array}$ & & & & 4 & 0 \\
\hline & EMU & BTAR* & $\begin{array}{c}0.361 \\
(1.435)\end{array}$ & 0.591 & $\begin{array}{l}-0.613 \\
(-1.647)\end{array}$ & $\begin{array}{c}3.026 \\
(0.093)\end{array}$ & $\begin{array}{l}-1.175 \\
(-3.704)\end{array}$ & 0.007 & 3 & 0 \\
\hline \multirow[t]{3}{*}{ Sweden } & full & STD & $\begin{array}{c}0.587 \\
(4.713)\end{array}$ & 0.662 & & & & & 2 & 4 \\
\hline & pre & SYM & $\begin{array}{c}0.819 \\
(4.182)\end{array}$ & 0.862 & $\begin{array}{c}0.274 \\
(2.336)\end{array}$ & & & & 4 & 4 \\
\hline & EMU & SYM & $\begin{array}{c}0.064 \\
(0.410)\end{array}$ & 0.292 & $\begin{array}{l}-0.289 \\
(-2.391)\end{array}$ & & & & 3 & 0 \\
\hline \multirow[t]{3}{*}{ UK } & full & MTAR* & $\begin{array}{c}0.098 \\
(1.258)\end{array}$ & 0.969 & $\begin{array}{c}-0.407 \\
(-0.388)\end{array}$ & $\begin{array}{l}-0.047 \\
(-1.605)\end{array}$ & & 1.823 & 1 & 3 \\
\hline & pre & STD & $\begin{array}{c}0.210 \\
(1.804)\end{array}$ & 0.630 & & & & & 1 & 1 \\
\hline & EMU & MTAR* & $\begin{array}{l}-0.073 \\
(-1.419)\end{array}$ & -0.041 & $\begin{array}{l}-0.416 \\
(-3.014)\end{array}$ & $\begin{array}{l}-1.286 \\
(-3.035)\end{array}$ & & -0.462 & 1 & 0 \\
\hline \multicolumn{11}{|c|}{ Panel C: Corporate Lending Rates } \\
\hline \multirow[t]{3}{*}{ Austria } & full & STD & $\begin{array}{c}0.251 \\
(5.449)\end{array}$ & 0.691 & & & & & 4 & 1 \\
\hline & pre & STD & $\begin{array}{c}0.129 \\
(1.978)\end{array}$ & 0.513 & & & & & 4 & 1 \\
\hline & EMU & SYM & $\begin{array}{c}0.196 \\
(3.571)\end{array}$ & 0.609 & $\begin{array}{c}-0.312 \\
(-3.362)\end{array}$ & & & & 1 & 4 \\
\hline \multirow[t]{3}{*}{ Belgium } & full & MTAR* & $\begin{array}{c}1.072 \\
(10.213)\end{array}$ & 0.921 & $\begin{array}{l}-0.325 \\
(-2.149)\end{array}$ & $\begin{array}{l}-0.413 \\
(-2.852)\end{array}$ & & -0.014 & 1 & 2 \\
\hline & pre & SYM & $\begin{array}{c}1.009 \\
(7.066)\end{array}$ & 0.934 & $\begin{array}{c}-0.481 \\
(-2.449)\end{array}$ & & & & 1 & 4 \\
\hline & EMU & MTAR* & $\begin{array}{c}1.234 \\
(7.528)\end{array}$ & 0.925 & $\begin{array}{l}-0.934 \\
(-3.207)\end{array}$ & $\begin{array}{c}0.403 \\
(0.124)\end{array}$ & & -0.238 & 3 & 1 \\
\hline \multirow[t]{3}{*}{ Denmark } & full & MTAR* & $\begin{array}{c}0.270 \\
(3.508)\end{array}$ & 0.714 & $\begin{array}{l}-1.383 \\
(-2.711)\end{array}$ & $\begin{array}{l}-0.144 \\
(-3.080)\end{array}$ & & 0.444 & 2 & 3 \\
\hline & pre & STD & $\begin{array}{c}0.119 \\
(0.923)\end{array}$ & 0.664 & & & & & 1 & 3 \\
\hline & EMU & SYM & $\begin{array}{c}0.274 \\
(2.810)\end{array}$ & 0.718 & $\begin{array}{l}-0.312 \\
(-3.515)\end{array}$ & & & & 3 & 0 \\
\hline \multirow[t]{3}{*}{ France } & full & MTAR* & $\begin{array}{c}0.451 \\
(3.895)\end{array}$ & 0.885 & $\begin{array}{c}0.100 \\
(0.720)\end{array}$ & $\begin{array}{c}-0.056 \\
(-2.309)\end{array}$ & & 0.369 & 4 & 4 \\
\hline & pre & STD & $\begin{array}{c}0.273 \\
(1.445)\end{array}$ & 0.876 & & & & & 4 & 4 \\
\hline & EMU & MTAR* & $\begin{array}{c}0.692 \\
(4.389)\end{array}$ & 0.829 & $\begin{array}{c}-0.753 \\
(-4.224)\end{array}$ & $\begin{array}{c}0.115 \\
(0.239)\end{array}$ & & -0.232 & 3 & 1 \\
\hline \multirow[t]{3}{*}{ Germany } & full & STD & $\begin{array}{c}0.130 \\
(2.304)\end{array}$ & 0.540 & & & & & 1 & 3 \\
\hline & pre & STD & $\begin{array}{c}0.167 \\
(1.611)\end{array}$ & 0.373 & & & & & 1 & 1 \\
\hline & EMU & STD & $\begin{array}{c}0.104 \\
(1.903)\end{array}$ & 0.558 & & & & & 2 & 2 \\
\hline Greece & EMU & STD & $\begin{array}{c}-0.049 \\
(-0.856)\end{array}$ & -0.077 & & & & & 0 & 1 \\
\hline
\end{tabular}


Table 5 continued: Extented Pass-Through of Money Market Rate Innovations onto Lending Rates in Europe

\begin{tabular}{|c|c|c|c|c|c|c|c|c|c|c|}
\hline \multirow[t]{2}{*}{ Country } & \multirow[t]{2}{*}{ Period } & \multirow[t]{2}{*}{ Model } & \multirow{2}{*}{$\begin{array}{c}\text { Impact } \\
\text { Multiplier } \\
\beta_{2}\end{array}$} & \multirow{2}{*}{$\begin{array}{c}\text { Long-run } \\
\text { Multiplier } \\
\theta\end{array}$} & \multicolumn{3}{|c|}{$\begin{array}{c}\text { Error Correction } \\
\text { Speed of Adjustment }\end{array}$} & \multirow{2}{*}{$\begin{array}{c}\text { Optimal } \\
\text { Threshold } \\
\mathrm{a}_{0} *\end{array}$} & \multicolumn{2}{|c|}{ Lags } \\
\hline & & & & & $\beta_{\mathrm{ECT}, 1}$ & $\beta_{\mathrm{ECT}, 2}$ & $\beta_{\mathrm{ECT}, 3}$ & & $\mathrm{k}^{*}$ & $\mathrm{n}^{*}$ \\
\hline \multirow[t]{3}{*}{ Ireland } & full & SYM & $\begin{array}{c}0.250 \\
(5.055)\end{array}$ & 0.564 & $\begin{array}{c}-0.104 \\
(-1.874)\end{array}$ & & & & 3 & 1 \\
\hline & pre & SYM & $\begin{array}{c}0.269 \\
(4.244)\end{array}$ & 0.582 & $\begin{array}{l}-0.175 \\
(-1.749)\end{array}$ & & & & 3 & 1 \\
\hline & EMU & STD & $\begin{array}{c}0.192 \\
(2.067)\end{array}$ & 0.624 & & & & & 1 & 1 \\
\hline \multirow[t]{3}{*}{ Italy } & full & STD & $\begin{array}{c}0.154 \\
(4.891)\end{array}$ & 0.845 & & & & & 3 & 3 \\
\hline & pre & STD & $\begin{array}{c}0.126 \\
(2.760)\end{array}$ & 0.843 & & & & & 3 & 3 \\
\hline & EMU & STD & $\begin{array}{c}0.134 \\
(2.630)\end{array}$ & 0.840 & & & & & 2 & 4 \\
\hline \multirow[t]{3}{*}{ Netherlands } & full & SYM & $\begin{array}{c}0.435 \\
(4.637)\end{array}$ & 1.075 & $\begin{array}{l}-0.248 \\
(-2.974)\end{array}$ & & & & 4 & 1 \\
\hline & pre & SYM & $\begin{array}{c}0.195 \\
(1.847)\end{array}$ & 1.040 & $\begin{array}{c}-0.212 \\
(-1.983)\end{array}$ & & & & 3 & 0 \\
\hline & EMU & SYM & $\begin{array}{l}0.406 \\
(2.304)\end{array}$ & 1.028 & $\begin{array}{c}-0.539 \\
(-3.370)\end{array}$ & & & & 4 & 0 \\
\hline \multirow[t]{4}{*}{ Portugal } & full & STD & $\begin{array}{c}0.392 \\
(2.012)\end{array}$ & 0.900 & & & & & 4 & 2 \\
\hline & pre & BTAR* & $\begin{array}{c}0.344 \\
(0.929)\end{array}$ & 1.442 & $\begin{array}{c}-1.335 \\
(-4.681)\end{array}$ & $\begin{array}{r}136.245 \\
(1.934)\end{array}$ & $\begin{array}{c}-0.084 \\
(-0.314)\end{array}$ & 0.006 & 2 & 0 \\
\hline & & TAR* & $\begin{array}{c}0.331 \\
(0.901)\end{array}$ & 1.442 & $\begin{array}{l}-1.351 \\
(-4.836)\end{array}$ & $\begin{array}{c}-0.524 \\
(-2.525)\end{array}$ & & 0.351 & 2 & 1 \\
\hline & EMU & MTAR* & $\begin{array}{c}0.345 \\
(1.999)\end{array}$ & 0.602 & $\begin{array}{c}-0.927 \\
(-3.499)\end{array}$ & $\begin{array}{l}-0.495 \\
(2.861)\end{array}$ & & -0.011 & 3 & 0 \\
\hline \multirow[t]{3}{*}{ Spain } & full & SYM & $\begin{array}{l}0.433 \\
(2.774)\end{array}$ & 0.966 & $\begin{array}{c}-0.021 \\
(-0.451)\end{array}$ & & & & 3 & 0 \\
\hline & pre & SYM & $\begin{array}{c}0.620 \\
(5.792)\end{array}$ & 1.036 & $\begin{array}{l}-0.147 \\
(1.078)\end{array}$ & & & & 1 & 1 \\
\hline & EMU & SYM & $\begin{array}{c}0.641 \\
(3.422)\end{array}$ & 0.887 & $\begin{array}{r}-1.018 \\
(-5.398)\end{array}$ & & & & 1 & 1 \\
\hline \multirow[t]{3}{*}{ Sweden } & full & STD & $\begin{array}{c}0.424 \\
(2.945)\end{array}$ & 0.515 & & & & & 0 & 3 \\
\hline & pre & SYM & $\begin{array}{l}0.661 \\
(2.930)\end{array}$ & 0.889 & $\begin{array}{r}0.055 \\
(0.647)\end{array}$ & & & & 3 & 2 \\
\hline & EMU & MTAR* & $\begin{array}{c}0.004 \\
(0.018)\end{array}$ & 0.534 & $\begin{array}{r}-0.429 \\
(-1.560)\end{array}$ & $\begin{array}{c}-0.439 \\
(-0.661)\end{array}$ & & -0.101 & 3 & 0 \\
\hline
\end{tabular}

Note: t-statistics are given in parentheses. 
Table A1: Nominal and Real Cost of Borrowing and Interest Rate Spreads - Descriptive Statistics

\begin{tabular}{|c|c|c|c|c|c|c|c|c|c|c|c|c|c|c|c|c|c|c|}
\hline \multirow[t]{3}{*}{ country } & \multicolumn{6}{|c|}{ mortgage lending rates } & \multicolumn{6}{|c|}{ consumer lending rates } & \multicolumn{6}{|c|}{ corporate lending rates } \\
\hline & \multicolumn{2}{|c|}{ full } & \multicolumn{2}{|c|}{ pre-EMU } & \multicolumn{2}{|c|}{ EMU } & \multicolumn{2}{|c|}{ full } & \multicolumn{2}{|c|}{ pre-EMU } & \multicolumn{2}{|c|}{ EMU } & \multicolumn{2}{|c|}{ full } & \multicolumn{2}{|c|}{ pre-EMU } & \multicolumn{2}{|c|}{ EMU } \\
\hline & mean & $\begin{array}{c}\text { stand. } \\
\text { dev. }\end{array}$ & mean & $\begin{array}{c}\text { stand. } \\
\text { dev. }\end{array}$ & mean & $\begin{array}{c}\text { stand. } \\
\text { dev. }\end{array}$ & mean & $\begin{array}{c}\text { stand. } \\
\text { dev. }\end{array}$ & mean & $\begin{array}{c}\text { stand. } \\
\text { dev. }\end{array}$ & mean & $\begin{array}{c}\text { stand. } \\
\text { dev. }\end{array}$ & mean & $\begin{array}{c}\text { stand. } \\
\text { dev. }\end{array}$ & mean & $\begin{array}{c}\text { stand. } \\
\text { dev. }\end{array}$ & mean & $\begin{array}{c}\text { stand. } \\
\text { dev. }\end{array}$ \\
\hline \multicolumn{19}{|c|}{ Panel A: Nominal cost of borrowing } \\
\hline Austria & 6.22 & 0.73 & 6.64 & 0.65 & 5.74 & 0.49 & 7.71 & 0.90 & 8.29 & 0.79 & 7.05 & 0.48 & 6.62 & 0.76 & 7.05 & 0.69 & 6.14 & 0.50 \\
\hline Belgium & 6.08 & 0.77 & 6.07 & 0.85 & 6.10 & 0.68 & 7.71 & 1.33 & 8.16 & 1.65 & 7.20 & 0.52 & 4.63 & 0.63 & 4.58 & 0.51 & 4.68 & 0.76 \\
\hline Denmark & & & & & & & 10.16 & 0.60 & 10.45 & 0.45 & 9.84 & 0.58 & 5.99 & 0.75 & 6.12 & 0.73 & 5.85 & 0.74 \\
\hline Finland & 5.83 & 1.07 & 6.36 & 1.07 & 5.23 & 0.68 & 7.02 & 1.13 & 7.58 & 1.16 & 6.40 & 0.68 & & & & & & \\
\hline France & 7.30 & 1.14 & 8.07 & 1.01 & 6.43 & 0.43 & 9.46 & 1.23 & 10.31 & 1.12 & 8.51 & 0.26 & 5.85 & 1.40 & 6.56 & 1.50 & 5.05 & 0.69 \\
\hline Germany & 5.96 & 0.69 & 6.17 & 0.70 & 5.73 & 0.60 & 11.00 & 0.79 & 11.47 & 0.80 & 10.48 & 0.28 & 8.09 & 0.52 & 7.95 & 0.39 & 8.25 & 0.61 \\
\hline Greece & 7.22 & 1.27 & & & 7.22 & 1.27 & 16.13 & 3.83 & & & 16.13 & 3.83 & 16.03 & 4.85 & 20.03 & 1.61 & 11.54 & 2.93 \\
\hline Ireland & 6.23 & 1.14 & 7.17 & 0.46 & 5.17 & 0.63 & & & & & & & 9.56 & 0.75 & 10.03 & 0.49 & 9.04 & 0.65 \\
\hline Italy & 8.78 & 3.03 & 11.09 & 2.38 & 6.17 & 0.50 & & & & & & & 8.41 & 2.66 & 10.48 & 2.01 & 6.09 & 0.53 \\
\hline Netherlands & 6.11 & 0.63 & 6.31 & 0.63 & 5.88 & 0.54 & & & & & & & 3.94 & 0.78 & 3.59 & 0.50 & 4.33 & 0.85 \\
\hline Portugal & 7.88 & 2.75 & 9.88 & 2.32 & 5.63 & 0.69 & 12.04 & 3.10 & 14.05 & 3.01 & 9.77 & 0.73 & 8.06 & 2.95 & 10.22 & 2.49 & 5.63 & 0.56 \\
\hline Spain & 6.92 & 2.20 & 8.27 & 2.23 & 5.41 & 0.61 & 9.93 & 2.50 & 11.54 & 2.45 & 8.11 & 0.55 & 6.14 & 2.02 & 7.35 & 2.03 & 4.77 & 0.74 \\
\hline Sweden & 7.23 & 1.05 & 7.73 & 1.18 & 6.67 & 0.45 & 7.67 & 1.49 & 8.62 & 1.45 & 6.55 & 0.18 & 6.43 & 1.79 & 7.43 & 1.77 & 5.07 & 0.26 \\
\hline UK & 7.20 & 0.97 & 7.91 & 0.70 & 6.41 & 0.49 & 17.43 & 1.79 & 18.93 & 1.04 & 15.74 & 0.37 & & & & & & \\
\hline \multicolumn{19}{|c|}{ Panel B: Real cost of borrowing } \\
\hline Austria & 4.70 & 0.67 & 5.20 & 0.29 & 4.13 & 0.51 & 6.19 & 0.85 & 6.85 & 0.41 & 5.45 & 0.54 & 5.11 & 0.71 & 5.61 & 0.31 & 4.53 & 0.57 \\
\hline Belgium & 4.32 & 0.82 & 4.68 & 0.89 & 3.91 & 0.48 & 5.94 & 1.53 & 6.77 & 1.67 & 5.02 & 0.50 & 2.87 & 0.68 & 3.20 & 0.74 & 2.50 & 0.35 \\
\hline Denmark & & & & & & & 8.10 & 0.86 & 8.67 & 0.64 & 7.49 & 0.62 & 3.93 & 0.88 & 4.34 & 0.76 & 3.50 & 0.81 \\
\hline Finland & 4.14 & 1.58 & 5.25 & 1.36 & 2.89 & 0.52 & 5.33 & 1.62 & 6.47 & 1.41 & 4.06 & 0.53 & & & & & & \\
\hline France & 5.84 & 1.02 & 6.63 & 0.61 & 4.96 & 0.52 & 8.01 & 1.14 & 8.88 & 0.73 & 7.03 & 0.59 & 4.40 & 1.15 & 5.13 & 1.06 & 3.58 & 0.52 \\
\hline Germany & 4.51 & 0.75 & 4.96 & 0.51 & 4.01 & 0.65 & 9.55 & 0.99 & 10.25 & 0.63 & 8.75 & 0.67 & 6.64 & 0.43 & 6.73 & 0.38 & 6.52 & 0.45 \\
\hline Greece & 4.19 & 1.98 & & & 4.19 & 1.98 & 13.10 & 4.62 & & & 13.10 & 4.62 & 9.78 & 4.03 & 14.03 & 0.81 & 8.50 & 3.71 \\
\hline Ireland & 3.88 & 2.94 & 6.30 & 1.48 & 1.16 & 1.35 & & & & & & & 7.21 & 2.43 & 9.15 & 1.51 & 5.02 & 0.99 \\
\hline Italy & 6.03 & 2.25 & 7.88 & 1.40 & 3.95 & 0.50 & & & & & & & 5.67 & 1.88 & 7.27 & 0.96 & 3.87 & 0.51 \\
\hline Netherlands & 3.66 & 1.54 & 4.61 & 0.73 & 2.59 & 1.51 & & & & & & & 1.49 & 1.03 & 1.89 & 0.53 & 1.04 & 1.26 \\
\hline Portugal & 4.84 & 2.76 & 7.94 & 2.10 & 2.48 & 0.77 & 8.99 & 3.05 & 11.11 & 2.76 & 6.62 & 0.70 & 5.01 & 2.93 & 7.28 & 2.14 & 2.47 & 0.86 \\
\hline Spain & 4.05 & 1.73 & 5.42 & 1.16 & 2.52 & 0.58 & 7.06 & 2.06 & 8.70 & 1.37 & 5.22 & 0.64 & 3.27 & 1.54 & 4.50 & 0.96 & 1.88 & 0.60 \\
\hline Sweden & 5.93 & 1.38 & 6.52 & 1.48 & 5.29 & 0.93 & 6.34 & 1.65 & 7.32 & 1.51 & 5.18 & 0.87 & 5.00 & 1.70 & 5.96 & 1.56 & 3.69 & 0.75 \\
\hline UK & 5.48 & 0.65 & 5.67 & 0.48 & 5.26 & 0.76 & 15.71 & 1.16 & 16.69 & 0.55 & 14.58 & 0.39 & & & & & & \\
\hline
\end{tabular}


Table A1 continued: Nominal and Real Cost of Borrowing and Interest Rate Spreads - Descriptive Statistics

\begin{tabular}{|c|c|c|c|c|c|c|c|c|c|c|c|c|c|c|c|c|c|c|}
\hline \multirow[t]{3}{*}{ country } & \multicolumn{6}{|c|}{ mortgage lending rates } & \multicolumn{6}{|c|}{ consumer lending rates } & \multicolumn{6}{|c|}{ corporate lending rates } \\
\hline & \multicolumn{2}{|c|}{ full } & \multicolumn{2}{|c|}{ pre-EMU } & \multicolumn{2}{|c|}{ EMU } & \multicolumn{2}{|c|}{ full } & \multicolumn{2}{|c|}{ pre-EMU } & \multicolumn{2}{|c|}{ EMU } & \multicolumn{2}{|c|}{ full } & \multicolumn{2}{|c|}{ pre-EMU } & \multicolumn{2}{|c|}{ EMU } \\
\hline & mean & $\begin{array}{c}\text { stand. } \\
\text { dev. }\end{array}$ & mean & $\begin{array}{c}\text { stand. } \\
\text { dev. }\end{array}$ & mean & $\begin{array}{c}\text { stand. } \\
\text { dev. }\end{array}$ & mean & $\begin{array}{c}\text { stand. } \\
\text { dev. }\end{array}$ & mean & $\begin{array}{c}\text { stand. } \\
\text { dev. }\end{array}$ & mean & $\begin{array}{c}\text { stand. } \\
\text { dev. }\end{array}$ & mean & $\begin{array}{c}\text { stand. } \\
\text { dev. }\end{array}$ & mean & $\begin{array}{c}\text { stand. } \\
\text { dev. }\end{array}$ & mean & $\begin{array}{c}\text { stand. } \\
\text { dev. }\end{array}$ \\
\hline \multicolumn{19}{|c|}{ Panel C: Spreads over Money Market Rate } \\
\hline Austria & 2.59 & 0.75 & 3.18 & 0.42 & 1.92 & 0.35 & 4.08 & 0.92 & 4.83 & 0.53 & 3.23 & 0.35 & 2.99 & 0.76 & 3.59 & 0.47 & 2.31 & 0.33 \\
\hline Belgium & 2.36 & 0.51 & 2.43 & 0.58 & 2.27 & 0.39 & 3.99 & 1.12 & 4.52 & 1.26 & 3.38 & 0.46 & 0.90 & 0.7 & 0.94 & 0.13 & 0.86 & 0.20 \\
\hline Denmark & & & & & & & 5.95 & 0.58 & 6.36 & 0.32 & 5.50 & 0.46 & 1.78 & 0.56 & 2.03 & 0.56 & 1.51 & 0.42 \\
\hline Finland & 1.96 & 0.61 & 2.45 & 0.39 & 1.41 & 0.21 & 3.15 & 0.66 & 3.66 & 0.48 & 2.57 & 0.22 & & & & & & \\
\hline France & 3.35 & 1.01 & 4.01 & 0.93 & 2.61 & 0.40 & 5.51 & 1.09 & 6.26 & 0.89 & 4.68 & 0.58 & 1.916 & 1.02 & 2.51 & 1.07 & 1.23 & 0.25 \\
\hline Germany & 2.31 & 0.64 & 2.67 & 0.49 & 1.91 & 0.55 & 7.35 & 0.87 & 7.96 & 0.53 & 6.65 & 0.63 & 4.43 & 0.31 & 4.44 & 0.22 & 4.42 & 0.39 \\
\hline Greece & 1.54 & 2.09 & & & 1.54 & 2.09 & 10.45 & 2.95 & & & 10.45 & 2.95 & 5.56 & 2.19 & 4.57 & 1.60 & 5.85 & 2.26 \\
\hline Ireland & 1.37 & 0.56 & 1.38 & 0.47 & 1.35 & 0.65 & & & & & & & 4.70 & 0.60 & 4.24 & 0.40 & 5.22 & 0.29 \\
\hline Italy & 2.92 & 0.78 & 3.43 & 0.65 & 2.35 & 0.44 & & & & & & & 2.56 & 0.52 & 2.82 & 0.48 & 2.26 & 0.41 \\
\hline Netherlands & 2.60 & 0.70 & 3.07 & 0.48 & 2.06 & 0.50 & & & & & & & 0.43 & 0.24 & 0.35 & 0.19 & 0.51 & 0.26 \\
\hline Portugal & 2.68 & 1.02 & 3.45 & 0.78 & 1.81 & 0.28 & 6.83 & 1.45 & 7.62 & 1.47 & 5.95 & 0.75 & 2.86 & 1.21 & 3.79 & 0.86 & 1.81 & 0.42 \\
\hline Spain & 1.68 & 0.36 & 1.76 & 0.42 & 1.61 & 0.27 & 4.69 & 0.67 & 5.04 & 0.64 & 4.29 & 0.44 & 0.89 & 0.27 & 0.84 & 0.28 & 0.95 & 0.24 \\
\hline Sweden & 2.92 & 0.72 & 2.83 & 0.84 & 3.01 & 0.57 & 3.17 & 0.43 & 3.40 & 0.37 & 2.90 & 0.34 & 1.60 & 0.37 & 1.74 & 0.39 & 1.41 & 0.23 \\
\hline UK & 1.40 & 1.02 & 1.47 & 1.22 & 1.32 & 0.74 & 11.62 & 1.51 & 12.48 & 1.40 & 10.63 & 0.93 & & & & & & \\
\hline
\end{tabular}

Note: "stand. dev." indicates standard deviation. All rates are given in percentage points per annum. Blank cells indicate that the interest rate series is not available. 
Table A2: Unit Root Tests

\begin{tabular}{|c|c|c|c|c|c|c|c|c|c|c|c|c|c|}
\hline \multicolumn{14}{|c|}{ consumer rates } \\
\hline country & period & $\mathrm{t}$ (level) & $\mathrm{F}$ (level) & $t($ diff $)$ & $\mathrm{F}$ (diff) & $\mathrm{t}($ level $)$ & $\mathrm{F}($ level) & $t($ diff $)$ & $F($ diff) & $\mathrm{t}($ level) & $\mathrm{F}$ (level) & $t($ diff $)$ & $\overline{F(\text { diff) }}$ \\
\hline \multirow[t]{3}{*}{ Austria } & full & -2.177 & 3.175 & -3.138 & 4.966 & -2.075 & 3.076 & -4.403 & 9.698 & -2.198 & 3.362 & -3.321 & 5.514 \\
\hline & pre-EMU & -2.302 & 5.073 & -3.387 & 5.750 & -2.034 & 2.723 & -4.216 & 8.898 & -2.094 & 5.882 & -3.657 & 6.723 \\
\hline & EMU & -1.116 & 0.768 & -1.824 & 1.739 & -1.545 & 1.210 & -2.103 & 2.218 & -1.235 & 0.973 & -2.219 & 2.473 \\
\hline \multirow[t]{3}{*}{ Belgium } & full & & 5.755 & -5.194 & 13.488 & -2.921 & 6.503 & -7.208 & 26.003 & -3.170 & 5.738 & -5.151 & 13.266 \\
\hline & pre-EMU & -2.369 & 4.000 & -4.184 & 8.762 & -2.050 & 3.235 & -5.603 & 15.714 & -3.472 & 7.513 & -4.466 & 9.995 \\
\hline & EMU & -0.935 & 1.337 & -3.610 & 6.524 & -1.169 & 1.014 & -3.714 & 6.941 & -0.977 & 1.025 & -3.384 & 5.807 \\
\hline \multirow[t]{3}{*}{ Denmark } & full & & & & & -2.345 & 2.984 & -6.061 & 18.372 & -2.596 & 4.938 & -6.358 & 20.217 \\
\hline & pre-EMU & & & & & -1.854 & 6.518 & -6.553 & 21.491 & -1.126 & 5.932 & -7.294 & 26.630 \\
\hline & EMU & & & & & -2.114 & 2.254 & -4.079 & 8.321 & -2.005 & 2.067 & -4.022 & 8.089 \\
\hline \multirow[t]{3}{*}{ Finland } & full & -2.127 & 2.880 & -4.000 & 8.006 & -2.025 & 2.907 & -6.671 & 22.267 & & & & \\
\hline & pre-EMU & -1.569 & 1.702 & -3.038 & 4.620 & -1.843 & 1.997 & -5.730 & 16.422 & & & & \\
\hline & EMU & -1.265 & 1.084 & -2.812 & 3.991 & -0.911 & 1.065 & -3.252 & 5.418 & & & & \\
\hline \multirow[t]{3}{*}{ France } & full & -0.951 & 0.927 & -7.217 & 26.050 & -0.950 & 1.770 & -7.717 & 29.794 & -1.329 & 0.887 & -6.436 & 20.716 \\
\hline & pre-EMU & -4.606 & 11.670 & -7.396 & 27.433 & -2.704 & 3.951 & -6.637 & 22.089 & -5.805 & 17.901 & -4.905 & 12.044 \\
\hline & EMU & -0.751 & 0.491 & -4.344 & 9.434 & -0.299 & 0.772 & -4.530 & 10.260 & -0.513 & 0.833 & -4.552 & 10.359 \\
\hline \multirow[t]{3}{*}{ Germany } & full & & 5.087 & -5.105 & 13.033 & -2.030 & 9.368 & -6.535 & 21.355 & -2.779 & 6.638 & -4.157 & 8.648 \\
\hline & pre-EMU & -3.781 & 7.406 & -4.203 & 8.882 & -1.840 & 4.097 & -6.060 & 18.413 & -3.972 & 15.969 & -6.184 & 19.136 \\
\hline & EMU & -1.816 & 1.971 & -3.401 & 5.807 & -2.204 & 2.480 & -2.669 & 3.662 & -1.533 & 1.277 & -2.057 & 2.118 \\
\hline \multirow[t]{3}{*}{ Greece } & full & -1.422 & 1.124 & -4.324 & 9.716 & -1.518 & 1.155 & -3.155 & 5.075 & -2.128 & 2.298 & -5.660 & 16.025 \\
\hline & pre-EMU & & & & & & & & & -3.917 & 9.857 & -4.594 & 10.556 \\
\hline & EMU & -1.422 & 1.124 & -4.324 & 9.716 & -1.518 & 1.155 & -3.155 & 5.075 & -2.942 & 4.824 & -4.318 & 9.331 \\
\hline \multirow[t]{3}{*}{ Ireland } & full & -1.977 & 2.016 & -6.292 & 20.272 & & & & & -2.005 & 2.093 & -4.923 & 12.227 \\
\hline & pre-EMU & -1.913 & 1.836 & -5.067 & 13.268 & & & & & -1.630 & 1.486 & -3.780 & 7.155 \\
\hline & EMU & -1.768 & 1.569 & -3.737 & 7.021 & & & & & -0.976 & 0.673 & -3.072 & 4.881 \\
\hline \multirow[t]{3}{*}{ Italy } & full & -0.329 & 0.717 & -5.760 & 16.953 & & & & & -1.210 & 1.517 & -3.589 & 7.322 \\
\hline & pre-EMU & -2.389 & 10.881 & -6.237 & 19.689 & & & & & -3.887 & 9.707 & -3.097 & 5.001 \\
\hline & EMU & -1.112 & 0.692 & -4.286 & 9.575 & & & & & -1.640 & 1.656 & -2.597 & 4.646 \\
\hline \multirow[t]{3}{*}{ Netherlands } & full & -2.920 & 6.102 & -5.066 & 12.942 & & & & & -1.528 & 1.169 & -4.433 & 10.035 \\
\hline & pre-EMU & -3.484 & 7.121 & -4.610 & 10.678 & & & & & -1.702 & 4.750 & -3.571 & 6.460 \\
\hline & EMU & -1.898 & 1.807 & -2.776 & 3.953 & & & & & 0.392 & 1.585 & -3.472 & 6.145 \\
\hline \multirow[t]{3}{*}{ Portugal } & full & -0.859 & 1.571 & -3.528 & 6.289 & -1.315 & 1.355 & -8.180 & 33.459 & -0.973 & 1.777 & -10.299 & 53.101 \\
\hline & pre-EMU & -1.549 & 3.338 & -4.213 & 8.953 & -3.918 & 8.006 & -6.243 & 19.502 & -4.319 & 9.453 & -8.997 & 40.694 \\
\hline & EMU & -1.223 & 0.933 & -2.231 & 2.603 & -2.247 & 2.734 & -6.860 & 23.596 & -1.221 & 0.806 & -4.774 & 11.636 \\
\hline \multirow[t]{3}{*}{ Spain } & full & -1.513 & 3.310 & -3.731 & 7.765 & -0.838 & 1.112 & -7.431 & 27.630 & -0.869 & 1.504 & -5.722 & 16.498 \\
\hline & pre-EMU & -1.709 & 1.474 & -3.289 & 6.229 & -3.215 & 6.092 & -4.024 & 8.425 & -1.736 & 1.545 & -4.325 & 9.467 \\
\hline & EMU & -1.978 & 2.484 & -2.560 & 3.423 & -1.667 & 1.586 & -7.595 & 29.174 & -0.834 & 0.483 & -3.955 & 7.871 \\
\hline \multirow[t]{3}{*}{ Sweden } & full & -1.511 & 2.677 & -6.364 & 20.256 & -2.853 & 11.301 & -9.292 & 43.197 & -0.447 & 2.738 & -7.584 & 28.769 \\
\hline & pre-EMU & -2.041 & 2.280 & -5.125 & 13.199 & -1.884 & 4.453 & -7.827 & 30.743 & -1.021 & 0.596 & -5.857 & 17.194 \\
\hline & EMU & -1.238 & 0.978 & -3.899 & 7.603 & -3.356 & 6.455 & -4.110 & 8.451 & -4.747 & 12.403 & -4.065 & 8.262 \\
\hline \multirow[t]{3}{*}{ UK } & full & -2.568 & 3.667 & -5.783 & 16.735 & -1.658 & 1.473 & -6.443 & 20.822 & & & & \\
\hline & pre-EMU & -2.049 & 2.098 & -4.904 & 12.040 & -1.956 & 1.927 & -4.430 & 9.818 & & & & \\
\hline & EMU & -1.934 & 1.921 & -3.341 & 5.583 & -5.662 & 21.362 & -5.432 & 14.763 & & & & \\
\hline
\end{tabular}


Table A2 continued: Unit Root Tests

\begin{tabular}{|c|c|c|c|c|c|c|c|c|c|c|c|c|c|}
\hline \multirow[b]{2}{*}{ country } & \multirow[b]{2}{*}{ period } & \multicolumn{4}{|c|}{ mortgage rates } & \multicolumn{3}{|c|}{ consumer rates } & \multicolumn{5}{|c|}{ corporate rates } \\
\hline & & $\mathrm{t}$ (level) & $\mathrm{F}($ level $)$ & $t($ diff $)$ & $F($ diff $)$ & $\mathrm{t}($ level) & $\mathrm{F}($ level) & $\mathrm{t}$ (diff) & $F($ diff $)$ & $\mathrm{t}$ (level) & F(level) & $\mathrm{t}($ diff $)$ & $F($ diff) \\
\hline \multirow[t]{3}{*}{ Austria } & full & -2.884 & 4.163 & -8.808 & 38.803 & -2.813 & 3.997 & -7.939 & 31.519 & -2.829 & 4.001 & -8.802 & 38.740 \\
\hline & pre-EMU & -2.815 & 4.290 & -6.580 & 21.684 & -2.422 & 3.150 & -5.803 & 16.882 & -2.541 & 3.562 & -6.583 & 21.708 \\
\hline & EMU & -2.225 & 3.041 & -6.062 & 18.390 & -2.239 & 3.083 & -5.505 & 15.174 & -2.174 & 2.680 & -5.925 & 17.582 \\
\hline \multirow[t]{3}{*}{ Belgium } & full & -3.137 & 5.731 & -5.864 & 17.319 & -2.685 & 5.123 & -6.317 & 20.114 & -3.225 & 5.791 & -6.632 & 22.175 \\
\hline & pre-EMU & -2.066 & 2.662 & -4.567 & 10.434 & -1.714 & 2.495 & -4.841 & 11.729 & -2.402 & 3.580 & -4.720 & 11.152 \\
\hline & EMU & -2.878 & 4.450 & -3.557 & 6.568 & -2.608 & 4.069 & -3.730 & 7.102 & -4.319 & 9.931 & -4.946 & 12.359 \\
\hline \multirow[t]{3}{*}{ Denmark } & full & & & & & -2.100 & 2.400 & -6.055 & 18.335 & -2.332 & 3.686 & -6.408 & 20.540 \\
\hline & pre-EMU & & & & & -1.850 & 4.179 & -5.138 & 13.203 & -1.279 & 6.515 & -6.437 & 20.720 \\
\hline & EMU & & & & & -3.641 & 8.188 & -4.686 & 10.981 & -3.112 & 6.225 & -4.836 & 11.699 \\
\hline \multirow[t]{3}{*}{ Finland } & full & -2.113 & 2.342 & -5.959 & 17.790 & -2.238 & 2.624 & -7.103 & 25.270 & & & & \\
\hline & pre-EMU & -1.526 & 1.276 & -3.736 & 7.037 & -1.833 & 1.742 & -5.078 & 12.911 & & & & \\
\hline & EMU & -2.541 & 3.452 & -4.927 & 12.146 & -2.291 & 2.693 & -4.711 & 11.095 & & & & \\
\hline \multirow[t]{3}{*}{ France } & full & -4.272 & 9.148 & -8.332 & 34.711 & -4.005 & 8.022 & -7.714 & 29.757 & -3.177 & 5.162 & -7.981 & 31.853 \\
\hline & pre-EMU & -2.913 & 4.293 & -5.539 & 15.339 & -2.693 & 3.690 & -5.649 & 15.956 & -4.321 & 9.418 & -5.101 & 13.013 \\
\hline & EMU & -3.119 & 4.875 & -5.990 & 17.977 & -2.914 & 4.252 & -5.053 & 12.798 & -1.839 & 1.821 & -6.641 & 22.077 \\
\hline \multirow[t]{3}{*}{ Germany } & full & -2.893 & 4.844 & -6.809 & 23.232 & -2.228 & 2.924 & -7.170 & 25.742 & -3.242 & 5.498 & -7.571 & 28.705 \\
\hline & pre-EMU & -2.482 & 3.693 & -4.913 & 12.074 & -1.173 & 1.492 & -5.262 & 13.924 & -1.529 & 2.400 & -6.075 & 18.509 \\
\hline & EMU & -1.560 & 1.537 & -4.596 & 10.622 & -1.560 & 2.418 & -5.148 & 13.310 & -2.461 & 3.594 & -5.086 & 13.024 \\
\hline \multirow[t]{3}{*}{ Greece } & full & -3.306 & 5.764 & -4.755 & 11.333 & -1.972 & 2.010 & -3.056 & 4.750 & -1.792 & 1.606 & -4.656 & 10.843 \\
\hline & pre-EMU & & & & & & & & & -2.513 & 7.096 & -5.347 & 14.737 \\
\hline & EMU & -3.306 & 5.764 & -4.755 & 11.333 & -1.972 & 2.010 & -3.056 & 4.750 & -1.751 & 1.540 & -3.885 & 7.626 \\
\hline \multirow[t]{3}{*}{ Ireland } & full & -2.040 & 2.329 & -6.024 & 18.143 & & & & & -2.087 & 2.399 & -6.200 & 19.233 \\
\hline & pre-EMU & -1.575 & 1.247 & -4.787 & 11.535 & & & & & -1.521 & 1.179 & -4.881 & 12.058 \\
\hline & EMU & -3.392 & 6.816 & -4.035 & 8.147 & & & & & -3.761 & 8.036 & -3.897 & 7.603 \\
\hline \multirow[t]{3}{*}{ Italy } & full & -1.414 & 1.010 & -6.918 & 24.022 & & & & & -1.582 & 1.288 & -6.488 & 21.140 \\
\hline & pre-EMU & 0.094 & 2.239 & -4.747 & 11.313 & & & & & 0.000 & 2.749 & -4.332 & 9.383 \\
\hline & EMU & -2.641 & 3.486 & -5.686 & 16.201 & & & & & -2.472 & 3.115 & -4.894 & 12.021 \\
\hline \multirow[t]{3}{*}{ Netherlands } & full & -2.313 & 2.705 & -6.405 & 20.578 & & & & & -1.563 & 1.587 & -7.242 & 26.226 \\
\hline & pre-EMU & -3.477 & 6.171 & -5.396 & 14.576 & & & & & -1.908 & 2.160 & -5.782 & 16.720 \\
\hline & EMU & -1.464 & 1.115 & -4.014 & 8.126 & & & & & -1.246 & 0.963 & -4.641 & 10.769 \\
\hline \multirow[t]{3}{*}{ Portugal } & full & -2.223 & 2.473 & -5.717 & 16.351 & -2.363 & 2.824 & -7.843 & 30.754 & -2.590 & 3.369 & -7.994 & 32.055 \\
\hline & pre-EMU & -1.778 & 3.383 & -4.294 & 9.230 & -3.156 & 5.668 & -6.131 & 18.794 & -3.140 & 5.946 & -6.170 & 19.225 \\
\hline & EMU & -2.491 & 3.428 & -4.901 & 12.107 & -3.208 & 5.452 & -7.071 & 25.080 & -2.623 & 3.566 & -5.268 & 14.062 \\
\hline \multirow[t]{3}{*}{ Spain } & full & -2.916 & 4.338 & -6.253 & 19.572 & -3.052 & 4.707 & -7.603 & 28.943 & -2.696 & 3.753 & -6.945 & 24.127 \\
\hline & pre-EMU & -3.222 & 5.524 & -3.855 & 7.436 & -4.014 & 9.527 & -4.870 & 12.431 & -2.720 & 4.093 & -4.445 & 9.888 \\
\hline & EMU & -2.850 & 4.074 & -4.512 & 10.249 & -2.982 & 4.449 & -5.547 & 15.583 & -2.865 & 4.112 & -4.916 & 12.129 \\
\hline \multirow[t]{3}{*}{ Sweden } & full & -1.576 & 1.243 & -6.310 & 19.918 & -1.915 & 1.837 & -7.124 & 25.373 & -1.860 & 1.827 & -7.387 & 27.294 \\
\hline & pre-EMU & -0.444 & 1.022 & -3.915 & 7.674 & -0.648 & 1.067 & -5.357 & 14.399 & -1.015 & 0.646 & -5.271 & 13.898 \\
\hline & EMU & -1.188 & 1.282 & -5.943 & 17.660 & -1.963 & 1.963 & -5.242 & 13.737 & -1.986 & 1.991 & -5.275 & 13.916 \\
\hline \multirow[t]{3}{*}{ UK } & full & -2.114 & 2.340 & -6.196 & 19.195 & -3.414 & 5.900 & -6.260 & 19.628 & & & & \\
\hline & pre-EMU & -1.894 & 1.911 & -4.910 & 12.188 & -2.839 & 4.200 & -5.094 & 13.069 & & & & \\
\hline & EMU & -1.250 & 1.386 & -3.772 & 7.148 & -4.782 & 12.519 & -4.066 & 8.268 & & & & \\
\hline
\end{tabular}


Table A2 continued: Unit Root Tests

\begin{tabular}{|c|c|c|c|c|c|c|c|c|c|c|c|c|c|}
\hline \multirow[b]{2}{*}{ Average series } & \multirow[b]{2}{*}{ period } & \multicolumn{4}{|c|}{ mortgage rates } & \multicolumn{4}{|c|}{ consumer rates } & \multicolumn{4}{|c|}{ corporate rates } \\
\hline & & $\mathrm{t}($ level $)$ & $\mathrm{F}$ (level) & $t($ diff $)$ & $F($ diff $)$ & $\mathrm{t}(\mathrm{level})$ & $\mathrm{F}($ level) & $t($ diff $)$ & $F($ diff $)$ & $\mathrm{t}($ level $)$ & $\mathrm{F}$ (level) & $t($ diff $)$ & $F($ diff $)$ \\
\hline \multirow[t]{3}{*}{ EU } & full & -1.152 & 3.191 & -4.218 & 9.191 & -1.142 & 5.567 & -5.932 & 17.633 & -1.297 & 1.594 & -3.483 & 6.163 \\
\hline & pre-EMU & -1.58 & 1.987 & -5.419 & 14.871 & -1.79 & 1.687 & -5.331 & 14.21 & -3.351 & 5.893 & -3.8 & 7.295 \\
\hline & EMU & -1.397 & 1.399 & -2.756 & 3.885 & -0.711 & 0.557 & -3.772 & 7.388 & -1.062 & 0.884 & -2.121 & 2.402 \\
\hline \multirow[t]{3}{*}{ EUaus } & full & -1.089 & 2.954 & -4.087 & 8.65 & -0.922 & 4.823 & -5.655 & 16.026 & -1.267 & 1.52 & -3.513 & 6.259 \\
\hline & pre-EMU & -1.611 & 2.352 & -5.048 & 12.922 & -1.858 & 1.728 & -4.854 & 11.783 & -3.57 & 6.741 & -3.794 & 7.262 \\
\hline & EMU & -1.364 & 1.366 & -2.763 & 3.905 & -0.699 & 0.559 & -3.893 & 7.87 & -1.061 & 0.892 & -2.144 & 2.464 \\
\hline \multirow[t]{3}{*}{ EUbel } & full & -1.07 & 3.158 & -4.25 & 9.355 & -0.975 & 4.548 & -6.071 & 18.451 & -1.24 & 1.484 & -3.528 & 6.312 \\
\hline & pre-EMU & -1.432 & 2.124 & -5.589 & 15.848 & -2.173 & 2.364 & -5.358 & 14.361 & -3.621 & 6.947 & -3.769 & 7.178 \\
\hline & EMU & -1.349 & 1.302 & -2.758 & 3.886 & -0.787 & 0.543 & -3.887 & 7.79 & -1.048 & 0.863 & -2.136 & 2.443 \\
\hline \multirow[t]{3}{*}{ EUfin } & full & -1.12 & 3.291 & -4.289 & 9.506 & -1.127 & 5.754 & -6.034 & 18.239 & & & & \\
\hline & pre-EMU & -1.478 & 1.919 & -5.546 & 15.606 & -1.807 & 1.721 & -5.388 & 14.518 & & & & \\
\hline & EMU & -1.356 & 1.316 & -2.776 & 3.928 & -0.712 & 0.546 & -3.825 & 7.611 & & & & \\
\hline \multirow[t]{3}{*}{ EUfra } & full & -1.248 & 3.568 & -4.722 & 11.409 & -1.402 & 5.855 & -6.368 & 20.296 & -1.568 & 2.527 & -3.55 & 6.439 \\
\hline & pre-EMU & -1.792 & 1.904 & -5.482 & 15.138 & -2.085 & 2.42 & -4.947 & 12.267 & -1.678 & 1.415 & -4.667 & 10.96 \\
\hline & EMU & -1.569 & 1.72 & -3.071 & 4.856 & -1.048 & 0.659 & -4.453 & 10.23 & -1.228 & 1.052 & -2.146 & 2.59 \\
\hline \multirow[t]{3}{*}{ EUger } & full & -0.737 & 2.648 & -4.212 & 9.515 & -0.908 & 3.617 & -6.503 & 21.192 & -1.192 & 1.061 & -3.829 & 7.419 \\
\hline & pre-EMU & -2.78 & 8.049 & -5.926 & 18.318 & -2.302 & 2.731 & -5.45 & 14.864 & -5.075 & 13.873 & -3.741 & 7.055 \\
\hline & EMU & -1.122 & 0.923 & -2.313 & 2.78 & -0.392 & 0.913 & -4.927 & 12.393 & -0.871 & 0.771 & -2.319 & 2.931 \\
\hline \multirow[t]{3}{*}{ EUire } & full & -1.141 & 3.262 & -4.224 & 9.208 & & & & & -1.274 & 1.568 & -3.495 & 6.194 \\
\hline & pre-EMU & -1.585 & 1.966 & -5.432 & 14.976 & & & & & -3.32 & 5.792 & -3.806 & 7.311 \\
\hline & EMU & -1.328 & 1.305 & -2.739 & 3.828 & & & & & -1.038 & 0.866 & -2.129 & 2.426 \\
\hline \multirow[t]{3}{*}{ EUita } & full & -1.847 & 4.008 & -4.32 & 9.421 & & & & & -1.437 & 1.904 & -3.906 & 7.637 \\
\hline & pre-EMU & -2.694 & 4.104 & -5.403 & 14.634 & & & & & -1.35 & 1.038 & -4.677 & 10.97 \\
\hline & EMU & -1.378 & 1.295 & -2.659 & 3.542 & & & & & -0.616 & 0.719 & -2.265 & 2.612 \\
\hline \multirow[t]{3}{*}{ EUnet } & full & -0.992 & 3.012 & -4.203 & 9.126 & & & & & -1.094 & 1.569 & -3.771 & 7.283 \\
\hline & pre-EMU & -1.548 & 2.836 & -5.455 & 15.091 & & & & & -4.028 & 8.802 & -3.855 & 7.538 \\
\hline & EMU & -1.192 & 1.224 & -2.891 & 4.327 & & & & & -1.079 & 0.829 & -2.324 & 2.817 \\
\hline \multirow[t]{3}{*}{ EUpor } & full & -1.159 & 3.246 & -4.294 & 9.509 & -1.26 & 6.081 & -5.946 & 17.71 & -1.325 & 1.632 & -3.54 & 6.386 \\
\hline & pre-EMU & -1.626 & 1.914 & -5.358 & 14.557 & -1.502 & 1.349 & -5.428 & 14.733 & -3.277 & 5.579 & -3.79 & 7.305 \\
\hline & EMU & -1.319 & 1.266 & -2.744 & 3.833 & -0.811 & 0.661 & -3.585 & 6.741 & -1.032 & 0.846 & -2.143 & 2.43 \\
\hline \multirow[t]{3}{*}{ EUspa } & full & -1.18 & 3.106 & -4.291 & 9.421 & -1.813 & 8.905 & -6.529 & 21.338 & -1.303 & 1.403 & -3.499 & 6.169 \\
\hline & pre-EMU & -1.077 & 1.24 & -5.036 & 12.805 & -1.727 & 2.71 & -6.947 & 24.286 & -4.345 & 9.975 & -3.882 & 7.565 \\
\hline & EMU & -1.314 & 1.249 & -2.872 & 4.196 & -0.781 & 0.437 & -2.653 & 3.606 & -1.221 & 1.096 & -2.176 & 2.512 \\
\hline
\end{tabular}


Table A2 continued: Unit Root Tests

Panel D: Real EU Average Lending Rates

\begin{tabular}{|c|c|c|c|c|c|c|c|c|c|c|c|c|c|}
\hline \multirow[t]{2}{*}{ country } & \multirow[b]{2}{*}{ period } & \multicolumn{4}{|c|}{ mortgage rates } & \multicolumn{4}{|c|}{ consumer rates } & \multicolumn{4}{|c|}{ corporate rates } \\
\hline & & $\mathrm{t}($ level) & F(level) & $t($ diff $)$ & $F($ diff $)$ & $\mathrm{t}($ level) & F(level) & $t($ diff $)$ & $F($ diff $)$ & $\mathrm{t}($ level) & F(level) & $t($ diff $)$ & $\mathrm{F}($ diff $)$ \\
\hline \multirow[t]{3}{*}{$\mathrm{EU}$} & full & -3.74 & 7.17 & -7.211 & 26.08 & -3.149 & 5.211 & -7.053 & 24.884 & -3.722 & 6.945 & -7.212 & 26.041 \\
\hline & pre-EMU & -3.033 & 4.622 & -4.777 & 11.422 & -2.593 & 3.447 & -5.061 & 12.81 & -4.248 & 9.042 & -5.143 & 13.229 \\
\hline & EMU & -4.219 & 9.1 & -5.188 & 13.476 & -2.645 & 3.916 & -4.829 & 11.667 & -2.936 & 4.41 & -4.852 & 11.78 \\
\hline \multirow[t]{3}{*}{ EUaus } & full & -3.647 & 6.81 & -7.183 & 25.877 & -3.121 & 5.061 & -6.996 & 24.482 & -3.676 & 6.775 & -7.228 & 26.152 \\
\hline & pre-EMU & -2.969 & 4.451 & -4.797 & 11.516 & -2.741 & 3.787 & -5.018 & 12.595 & -4.328 & 9.395 & -5.269 & 13.882 \\
\hline & EMU & -4.166 & 8.876 & -5.133 & 13.195 & -2.62 & 3.84 & -4.801 & 11.533 & -2.92 & 4.357 & -4.804 & 11.548 \\
\hline \multirow[t]{3}{*}{ EUbel } & full & -3.547 & 6.423 & -7.295 & 26.676 & -3.399 & 5.926 & -7.178 & 25.769 & -3.647 & 6.688 & -7.182 & 25.811 \\
\hline & pre-EMU & -2.705 & 3.711 & -4.838 & 11.716 & -3.008 & 4.553 & -5.139 & 13.214 & -4.156 & 8.689 & -5.205 & 13.547 \\
\hline & EMU & -4.062 & 8.436 & -5.25 & 13.796 & -2.661 & 3.911 & -4.9 & 12.008 & -2.873 & 4.215 & -4.79 & 11.477 \\
\hline \multirow[t]{3}{*}{ EUfin } & full & -3.719 & 7.087 & -7.219 & 26.135 & -3.212 & 5.411 & -7.032 & 24.738 & & & & \\
\hline & pre-EMU & -2.929 & 4.314 & -4.795 & 11.509 & -2.687 & 3.696 & -5.111 & 13.066 & & & & \\
\hline & EMU & -4.187 & 8.964 & -5.187 & 13.47 & -2.624 & 3.872 & -4.782 & 11.444 & & & & \\
\hline \multirow[t]{3}{*}{ EUfra } & full & -2.664 & 3.976 & -6.727 & 22.726 & -2.617 & 3.842 & -7.111 & 25.301 & -3.485 & 6.073 & -6.854 & 23.53 \\
\hline & pre-EMU & -2.296 & 2.711 & -4.674 & 10.937 & -2.361 & 2.881 & -4.875 & 11.891 & -4.013 & 8.052 & -5.153 & 13.279 \\
\hline & EMU & -4.392 & 9.835 & -5.12 & 13.111 & -2.391 & 3.514 & -5.056 & 12.786 & -3.355 & 5.894 & -4.656 & 10.844 \\
\hline \multirow[t]{3}{*}{ EUger } & full & -2.548 & 3.256 & -6.734 & 22.741 & -3.308 & 5.542 & -6.734 & 22.672 & -2.964 & 4.595 & -6.951 & 24.172 \\
\hline & pre-EMU & -1.666 & 1.775 & -4.432 & 9.838 & -3.214 & 5.187 & -4.73 & 11.269 & -3.966 & 8.525 & -5.003 & 12.522 \\
\hline & EMU & -3.714 & 6.935 & -5.177 & 13.402 & -3.241 & 5.262 & -4.543 & 10.332 & -2.145 & 2.301 & -4.67 & 10.908 \\
\hline \multirow[t]{3}{*}{ EUire } & full & -3.749 & 7.221 & -7.239 & 26.275 & & & & & -3.763 & 7.097 & -7.279 & 26.523 \\
\hline & pre-EMU & -3.121 & 4.894 & -4.802 & 11.541 & & & & & -4.413 & 9.756 & -5.272 & 13.9 \\
\hline & EMU & -4.029 & 8.283 & -5.2 & 13.538 & & & & & -2.889 & 4.26 & -4.852 & 11.784 \\
\hline \multirow[t]{3}{*}{ EUita } & full & -4.355 & 9.682 & -7.503 & 28.186 & & & & & -3.701 & 6.859 & -7.591 & 28.818 \\
\hline & pre-EMU & -3.039 & 4.846 & -5.225 & 13.652 & & & & & -2.256 & 2.632 & -5.267 & 13.87 \\
\hline & EMU & -3.009 & 4.781 & -5.141 & 13.273 & & & & & -3.003 & 4.583 & -5.286 & 13.999 \\
\hline \multirow[t]{3}{*}{ EUnet } & full & -3.311 & 5.641 & -7.39 & 27.358 & & & & & -3.27 & 5.347 & -7.466 & 27.908 \\
\hline & pre-EMU & -2.719 & 3.75 & -4.765 & 11.363 & & & & & -4.461 & 10.042 & -5.322 & 14.163 \\
\hline & EMU & -4.634 & 10.914 & -5.274 & 13.912 & & & & & -3.047 & 4.801 & -5.047 & 12.745 \\
\hline \multirow[t]{3}{*}{ EUpor } & full & -4.001 & 8.187 & -7.285 & 26.616 & -3.111 & 5.095 & -7.063 & 24.954 & -3.724 & 6.955 & -7.197 & 25.938 \\
\hline & pre-EMU & -3.297 & 5.438 & -4.742 & 11.257 & -2.194 & 2.601 & -5.129 & 13.159 & -3.978 & 7.914 & -5.116 & 13.092 \\
\hline & EMU & -4.354 & 9.71 & -5.278 & 13.948 & -2.629 & 3.912 & -4.812 & 11.589 & -2.929 & 4.399 & -4.855 & 11.799 \\
\hline \multirow[t]{3}{*}{ EUspa } & full & -3.771 & 7.395 & -7.329 & 26.967 & -2.992 & 4.952 & -7.184 & 25.84 & -3.92 & 7.692 & -7.266 & 26.443 \\
\hline & pre-EMU & -3.015 & 4.547 & -4.847 & 11.765 & -1.983 & 2.522 & -5.207 & 13.596 & -4.088 & 8.357 & -5.205 & 13.548 \\
\hline & EMU & -3.433 & 6.15 & -5.248 & 13.811 & -2.282 & 3.208 & -5.015 & 12.632 & -2.813 & 4.076 & -4.893 & 11.994 \\
\hline
\end{tabular}

Note: $\mathrm{t}($ level) and $\mathrm{F}($ level) give unit-root test-statistics for the level regression of equation (2.1) whereas $\mathrm{t}(\mathrm{diff})$ and $\mathrm{F}($ diff) give the unit-root test-statistics for the regression in first differences of equation (2.2). The critical values for 100 observations are as follows: $-3.46(1 \%),-2.88(5 \%),-2.57(10 \%)$ for the $t$ test and $8.73(1 \%), 6.49(5 \%), 5.47(10 \%)$ for the F test. Blank cells indicate that the interest rate series is not available. 
Table A3: Cointegration of Lending Rates

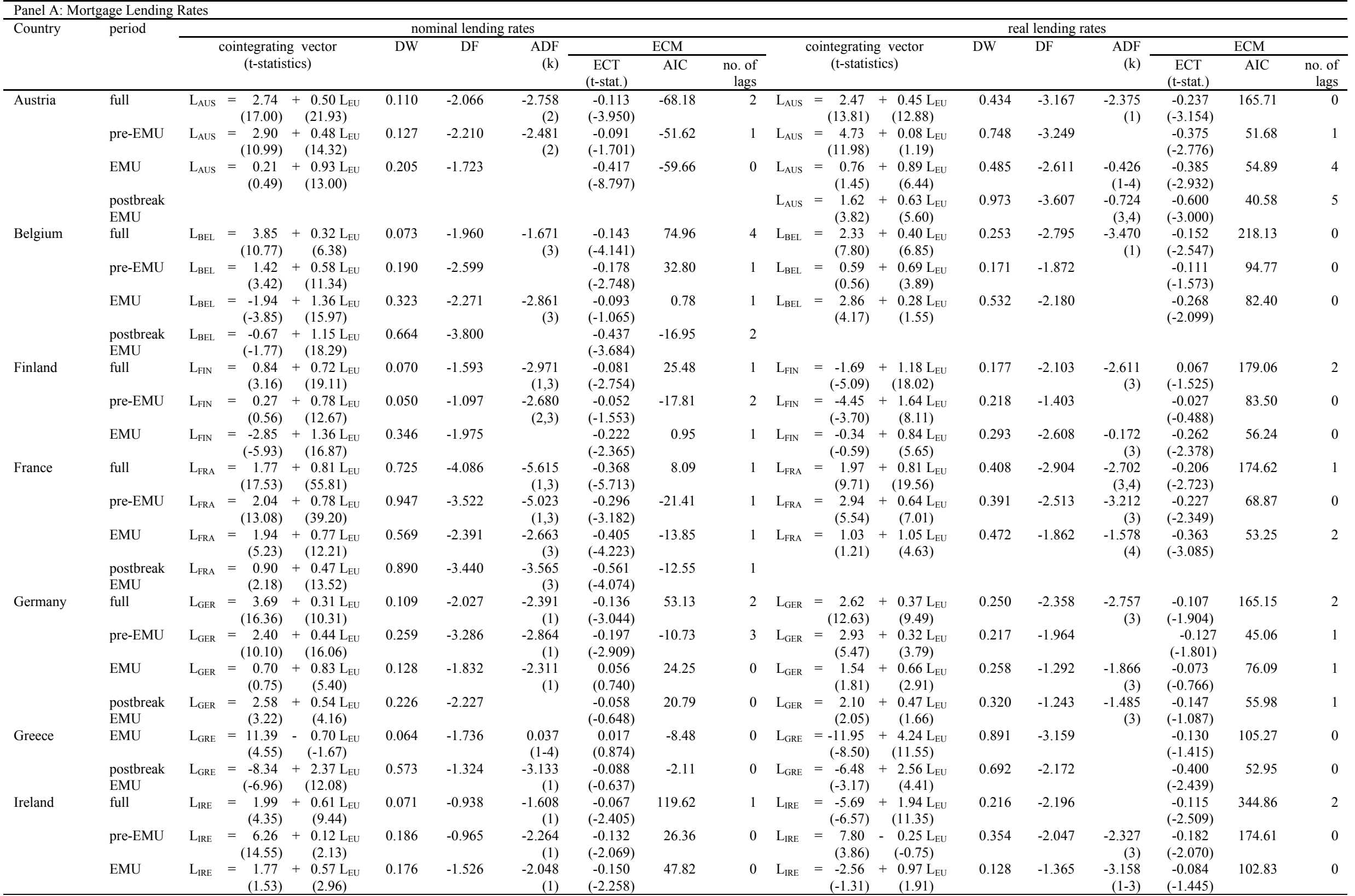




\begin{tabular}{|c|c|c|c|c|c|c|c|c|c|c|c|c|c|c|c|c|c|}
\hline \multirow[t]{3}{*}{ Country } & \multirow[t]{3}{*}{ period } & \multicolumn{8}{|c|}{ nominal lending rates } & \multicolumn{8}{|c|}{ real lending rates } \\
\hline & & \multirow{2}{*}{\multicolumn{2}{|c|}{$\begin{array}{l}\text { cointegrating vector } \\
\text { (t-statistics) }\end{array}$}} & \multirow[t]{2}{*}{ DW } & \multirow[t]{2}{*}{ DF } & \multirow{2}{*}{$\begin{array}{r}\mathrm{ADF} \\
(\mathrm{k})\end{array}$} & \multicolumn{3}{|c|}{ ECM } & \multirow{2}{*}{\multicolumn{2}{|c|}{$\begin{array}{l}\text { cointegrating vector } \\
\text { (t-statistics) }\end{array}$}} & \multirow[t]{2}{*}{ DW } & \multirow[t]{2}{*}{$\mathrm{DF}$} & \multirow{2}{*}{$\begin{array}{r}\mathrm{ADF} \\
(\mathrm{k})\end{array}$} & \multicolumn{3}{|c|}{ ECM } \\
\hline & & & & & & & $\begin{array}{c}\text { ECT } \\
\text { (t-stat.) }\end{array}$ & AIC & $\begin{array}{r}\text { no. of } \\
\text { lags }\end{array}$ & & & & & & $\begin{array}{c}\text { ECT } \\
\text { (t-stat.) }\end{array}$ & AIC & $\begin{array}{r}\text { no. of } \\
\text { lags }\end{array}$ \\
\hline \multirow[t]{3}{*}{ Italy } & full & $\mathrm{L}_{\text {ITA }}$ & $\begin{array}{c}=\underset{-9.43}{-9.81)}+2.80 \mathrm{~L}_{\mathrm{EU}} \\
(-9.14)\end{array}$ & 0.060 & -1.753 & $\begin{array}{r}-1.719 \\
(1,3)\end{array}$ & $\begin{array}{l}-0.108 \\
(-5.732)\end{array}$ & 117.14 & 1 & $\mathrm{~L}_{\text {ITA }}$ & $\begin{array}{c}=-2.48+1.82 \mathrm{~L}_{\mathrm{EU}} \\
(-3.73) \\
(13.07)\end{array}$ & 0.126 & -1.812 & $\begin{array}{r}-2.174 \\
(3)\end{array}$ & $\begin{array}{c}-0.048 \\
(-1.743)\end{array}$ & 198.81 & 1 \\
\hline & pre-EMU & $\mathrm{L}_{\text {ITA }}$ & $\begin{array}{c}=-5.14+2.30 \mathrm{~L}_{\mathrm{EU}} \\
(-5.79) \quad(18.46)\end{array}$ & 0.143 & -2.572 & & $\begin{array}{c}-0.054 \\
(-0.964)\end{array}$ & 62.63 & 1 & $\mathrm{~L}_{\text {ITA }}$ & 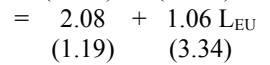 & 0.067 & 0.230 & $\begin{array}{r}-0.494 \\
(3)\end{array}$ & $\begin{array}{c}0.014 \\
(0.370)\end{array}$ & 76.90 & 1 \\
\hline & EMU & $\mathrm{L}_{\mathrm{ITA}}$ & $=\underset{(2.85)}{2.02}+\begin{array}{l}0.71 \mathrm{~L}_{\mathrm{EU}} \\
(5.89)\end{array}$ & 0.220 & -1.704 & $\begin{array}{r}-1.837 \\
(3)\end{array}$ & $\begin{array}{c}-0.263 \\
(-3.832)\end{array}$ & 14.57 & 1 & $\mathrm{~L}_{\text {ITA }}$ & $=\begin{array}{c}4.20-0.07 \mathrm{~L}_{\mathrm{EU}} \\
(6.81)-(-0.41)\end{array}$ & 0.523 & -2.600 & & $\begin{array}{c}-0.274 \\
(-2.483)\end{array}$ & 78.39 & 0 \\
\hline \multirow[t]{4}{*}{ Netherlands } & full & $\mathrm{L}_{\mathrm{NET}}$ & $=\frac{3.68}{(17.50)}+0.35 \mathrm{~L}_{\mathrm{EU}}$ & 0.126 & -2.348 & $\begin{array}{r}-2.320 \\
(1)\end{array}$ & $\begin{array}{l}-0.175 \\
(-4.229)\end{array}$ & 41.84 & 1 & $\mathrm{~L}_{\mathrm{NET}}$ & $\begin{aligned}= & -1.39+1.00 \mathrm{~L}_{\mathrm{EU}} \\
(-2.97) & (11.07)\end{aligned}$ & 0.173 & -1.934 & $\begin{array}{r}-2.264 \\
(3)\end{array}$ & $\begin{array}{l}-0.075 \\
(-1.829)\end{array}$ & 217.25 & 2 \\
\hline & pre-EMU & $\mathrm{L}_{\mathrm{NET}}$ & $=\underset{(10.57)}{2.84}+\frac{0.43 \mathrm{~L}_{\mathrm{EU}}}{(13.06)}$ & 0.240 & -3.376 & $\begin{array}{r}-2.852 \\
(1,4)\end{array}$ & $\begin{array}{l}-0.198 \\
(-2.759)\end{array}$ & 7.86 & 0 & $\mathrm{~L}_{\mathrm{NET}}$ & $=\begin{array}{c}-1.37+0.98 \mathrm{~L}_{\mathrm{EU}} \\
(-2.83) \quad(12.40)\end{array}$ & 0.591 & -2.656 & & $\begin{array}{l}-0.216 \\
(-1.392)\end{array}$ & 86.40 & 1 \\
\hline & EMU & $\mathrm{L}_{\mathrm{NET}}$ & $=\frac{-0.07}{(-0.12)}+1.00 \mathrm{~L}_{\mathrm{EU}}$ & 0.182 & -1.149 & $\begin{array}{r}-2.411 \\
(1,3)\end{array}$ & $\begin{array}{l}-0.036 \\
(-0.352)\end{array}$ & 0.081 & 1 & $\mathrm{~L}_{\mathrm{NET}}$ & $=\begin{array}{l}-5.06 \\
(-2.07)\end{array}$ & 0.245 & -1.651 & & $\begin{array}{c}-0.061 \\
(-1.187)\end{array}$ & 92.53 & 2 \\
\hline & $\begin{array}{l}\text { postbreak } \\
\text { EMU }\end{array}$ & $\mathrm{L}_{\mathrm{NET}}$ & $=\begin{array}{l}1.60+0.73 \mathrm{~L}_{\mathrm{EU}} \\
(2.45) \\
(6.83)\end{array}$ & 0.224 & -1.422 & $\begin{array}{r}-1.861 \\
(3)\end{array}$ & $\begin{array}{l}-0.266 \\
(-1.945)\end{array}$ & -10.00 & 3 & $\mathrm{~L}_{\mathrm{NET}}$ & $\begin{aligned}-0.59 & +0.45 \mathrm{~L}_{\mathrm{EU}} \\
(-0.28) & (0.78)\end{aligned}$ & 0.653 & -4.643 & & $\begin{array}{c}-0.586 \\
(-3.685)\end{array}$ & 35.46 & 1 \\
\hline \multirow[t]{3}{*}{ Portugal } & full & $\mathrm{L}_{\mathrm{POR}}$ & $\begin{array}{c}=-6.34 \\
(-17.75)\end{array}$ & 0.113 & -1.694 & $\begin{array}{r}-1.979 \\
(3)\end{array}$ & $\begin{array}{c}-0.071 \\
(-2.838)\end{array}$ & 29.62 & 3 & $\mathrm{~L}_{\mathrm{POR}}$ & $\begin{array}{c}=-6.24 \\
(-14.92)\end{array}$ & 0.370 & -3.005 & $\begin{array}{r}-3.482 \\
(1)\end{array}$ & $\begin{array}{c}-0.052 \\
(-1.087)\end{array}$ & 200.40 & 4 \\
\hline & pre-EMU & $\mathrm{L}_{\mathrm{POR}}$ & $=\begin{aligned}-4.70 & +1.88 \mathrm{~L}_{\mathrm{EU}} \\
(-8.61) & (27.02)\end{aligned}$ & 0.123 & -1.542 & & $\begin{array}{l}-0.074 \\
(-2.272)\end{array}$ & -8.22 & 2 & $\mathrm{~L}_{\mathrm{POR}}$ & $\begin{aligned}= & -10.95+3.03 \mathrm{~L}_{\mathrm{EU}} \\
& (-8.36) \quad(13.73)\end{aligned}$ & 0.338 & -2.213 & $\begin{array}{r}-2.299 \\
(2)\end{array}$ & $\begin{array}{c}-0.063 \\
(-0.991)\end{array}$ & 91.87 & 3 \\
\hline & EMU & $\mathrm{L}_{\mathrm{POR}}$ & $=\begin{aligned}-1.79 & +1.25 \mathrm{~L}_{\mathrm{EU}} \\
(-2.42) & (10.09)\end{aligned}$ & 0.188 & -1.739 & $\begin{array}{r}-1.955 \\
(3)\end{array}$ & $\begin{array}{c}-0.273 \\
(-4.391)\end{array}$ & 4.94 & 0 & $\mathrm{~L}_{\mathrm{POR}}$ & $=\begin{array}{r}-2.62+1.33 \mathrm{~L}_{\mathrm{EU}} \\
(-3.11) \\
(6.07)\end{array}$ & 0.615 & -2.632 & & $\begin{array}{c}-0.033 \\
(-0.398)\end{array}$ & 63.02 & 1 \\
\hline \multirow[t]{4}{*}{ Spain } & full & $\mathrm{L}_{\mathrm{SPA}}$ & $=\frac{-4.95}{(-15.60)}+\frac{1.71 \mathrm{~L}_{\mathrm{EU}}}{(38.00)}$ & 0.116 & -1.550 & $\begin{array}{r}-2.323 \\
(2)\end{array}$ & $\begin{array}{l}-0.035 \\
(-1.940)\end{array}$ & -39.34 & 2 & $\mathrm{~L}_{\mathrm{SPA}}$ & $=\frac{-2.87}{(-8.60)}+1.38 \mathrm{~L}_{\mathrm{EU}}$ & 0.243 & -2.206 & & $\begin{array}{l}-0.120 \\
(-2.545)\end{array}$ & 179.26 & 3 \\
\hline & pre-EMU & $\mathrm{L}_{\mathrm{SPA}}$ & $=\frac{-6.71}{(11.59)}+1.93 \mathrm{~L}_{\mathrm{EU}}$ & 0.138 & -0.473 & $\begin{array}{r}-1.349 \\
(2)\end{array}$ & $\begin{array}{c}-0.065 \\
(-2.439)\end{array}$ & -32.93 & 1 & $\mathrm{~L}_{\mathrm{SPA}}$ & $=\frac{-4.75}{(-6.00)}+1.70 \mathrm{~L}_{\mathrm{EU}}$ & 0.348 & -2.319 & & $\begin{array}{c}-0.141 \\
(-1.967)\end{array}$ & 59.36 & 2 \\
\hline & EMU & $\mathrm{L}_{\mathrm{SPA}}$ & $=\frac{-1.56+1.16 \mathrm{~L}_{\mathrm{EU}}}{(-2.57) \quad(11.52)}$ & 0.182 & -1.388 & $\begin{array}{r}-2.047 \\
(1)\end{array}$ & $\begin{array}{l}-0.210 \\
(-5.106)\end{array}$ & -64.59 & 1 & $\mathrm{~L}_{\mathrm{SPA}}$ & $=\begin{array}{l}1.93+0.15 \mathrm{~L}_{\mathrm{EU}} \\
(2.33) \quad(0.70)\end{array}$ & 0.430 & -2.099 & $\begin{array}{r}-2.565 \\
(1)\end{array}$ & $\begin{array}{c}-0.296 \\
(-3.016)\end{array}$ & 68.15 & 3 \\
\hline & $\begin{array}{l}\text { postbreak } \\
\text { EMU }\end{array}$ & & & & & & & & & $\mathrm{L}_{\mathrm{SPA}}$ & $=\begin{aligned}-1.39 & +1.14 \mathrm{~L}_{\mathrm{EU}} \\
(-0.72) & (2.09)\end{aligned}$ & 0.569 & -1.204 & & $\begin{array}{c}-0.321 \\
(-1.488)\end{array}$ & 39.35 & 1 \\
\hline \multirow[t]{4}{*}{ Sweden } & full & $\mathrm{L}_{\mathrm{SWE}}$ & $=\underset{(3.93)}{1.26}+\underset{(18.78)}{0.89 \mathrm{~L}_{\mathrm{EU}}}$ & 0.243 & -2.163 & $\begin{array}{r}-2.679 \\
(3)\end{array}$ & $\begin{array}{l}-0.162 \\
(-2.297)\end{array}$ & 84.69 & 2 & $\mathrm{~L}_{\mathrm{SWE}}$ & $=\begin{array}{l}1.30+0.95 \mathrm{~L}_{\mathrm{EU}} \\
(2.29) \quad(8.27)\end{array}$ & 0.135 & -1.282 & $\begin{array}{r}-1.961 \\
(3)\end{array}$ & $\begin{array}{c}-0.073 \\
(-1.558)\end{array}$ & 159.36 & 2 \\
\hline & pre-EMU & $\mathrm{L}_{\mathrm{SWE}}$ & $=\underset{(-1.90)}{-0.66}+1.13 \mathrm{~L}_{\mathrm{EU}}$ & 0.677 & -2.082 & $\begin{array}{r}-2.191 \\
(3)\end{array}$ & $\begin{array}{c}-0.322 \\
(-1.961)\end{array}$ & 38.04 & 0 & $\mathrm{~L}_{\mathrm{SWE}}$ & $\begin{array}{c}=-4.00+1.83 \mathrm{~L}_{\mathrm{EU}} \\
(-2.36) \\
(6.24)\end{array}$ & 0.154 & -0.640 & $\begin{array}{r}-1.395 \\
(3)\end{array}$ & $\begin{array}{c}-0.078 \\
(-1.340)\end{array}$ & 54.18 & 2 \\
\hline & EMU & $\mathrm{L}_{\mathrm{SWE}}$ & $=\begin{aligned} 4.00 & +0.45 \mathrm{~L}_{\mathrm{EU}} \\
(4.90) & (3.28)\end{aligned}$ & 0.218 & -1.686 & $\begin{array}{r}-2.292 \\
(3)\end{array}$ & $\begin{array}{l}-0.313 \\
(-2.632)\end{array}$ & 10.07 & 3 & $\mathrm{~L}_{\mathrm{SWE}}$ & $\begin{aligned}= & -3.23+2.17 \mathrm{~L}_{\mathrm{EU}} \\
(-3.03) & (8.03)\end{aligned}$ & 0.746 & -2.266 & & $\begin{array}{c}0.045 \\
(0.299)\end{array}$ & 63.76 & 2 \\
\hline & $\begin{array}{l}\text { postbreak } \\
\text { EMU }\end{array}$ & $\mathrm{L}_{\mathrm{SWE}}$ & $=\begin{array}{c}6.46 \\
(7.06)\end{array}$ & 0.392 & -3.010 & & $\begin{array}{l}-0.228 \\
(-1.701)\end{array}$ & 3.28 & 2 & & & & & & & & \\
\hline \multirow[t]{4}{*}{ UK } & full & $\mathrm{L}_{\mathrm{UKD}}$ & $=\underset{(10.52)}{2.76}+\underset{(17.20)}{0.64 \mathrm{~L}_{\mathrm{EU}}}$ & 0.116 & -1.664 & $\begin{array}{r}-2.335 \\
(1,4)\end{array}$ & $\begin{array}{l}-0.074 \\
(-1.925)\end{array}$ & 71.84 & 2 & $\mathrm{~L}_{\mathrm{UKD}}$ & $=\underset{(15.65)}{4.43}+\frac{0.21 \mathrm{~L}_{\mathrm{EU}}}{(3.81)}$ & 0.184 & -1.860 & & $\begin{array}{l}-0.082 \\
(-1.585)\end{array}$ & 162.84 & 3 \\
\hline & pre-EMU & $\mathrm{L}_{\mathrm{UKD}}$ & $=\underset{(12.17)}{4.00}+0.50 \mathrm{~L}_{\mathrm{EU}}$ & 0.255 & -2.361 & $\begin{array}{r}-2.035 \\
(4)\end{array}$ & $\begin{array}{l}-0.210 \\
(-2.871)\end{array}$ & 15.51 & 1 & $\mathrm{~L}_{\mathrm{UKD}}$ & $=\underset{(8.08)}{5.35}+\underset{0.05 \mathrm{~L}_{\mathrm{EU}}}{(0.49)}$ & 0.340 & -1.930 & & $\begin{array}{l}-0.159 \\
(-1.835)\end{array}$ & 66.36 & 1 \\
\hline & EMU & $\mathrm{L}_{\mathrm{UKD}}$ & $\begin{aligned}= & 4.39+0.34 \mathrm{~L}_{\mathrm{EU}} \\
(4.61) & (2.13)\end{aligned}$ & 0.075 & 0.721 & $\begin{array}{r}-1.299 \\
(1)\end{array}$ & $\begin{array}{l}-0.048 \\
(-0.600)\end{array}$ & 3.46 & 2 & $\mathrm{~L}_{\mathrm{UKD}}$ & $=\begin{array}{l}1.76+0.92 \mathrm{~L}_{\mathrm{EU}} \\
(1.75) \quad(3.50)\end{array}$ & 0.107 & -2.175 & $\begin{array}{r}-2.080 \\
(3)\end{array}$ & $\begin{array}{l}-0.106 \\
(-1.557)\end{array}$ & 50.98 & 2 \\
\hline & $\begin{array}{l}\text { postbreak } \\
\text { EMU }\end{array}$ & $\mathrm{L}_{\mathrm{UKD}}$ & $=\begin{array}{l}2.56 \\
(3.26)\end{array}+\begin{array}{l}0.57 \mathrm{~L}_{\mathrm{EU}} \\
(4.48)\end{array}$ & 0.546 & -2.906 & $\begin{array}{r}-3.386 \\
(1,4) \\
\end{array}$ & $\begin{array}{c}-0.490 \\
(-3.284)\end{array}$ & -17.43 & 2 & $\mathrm{~L}_{\mathrm{UKD}}$ & $\begin{aligned}=-0.81 & +1.67 \mathrm{~L}_{\mathrm{EU}} \\
(-1.24) & (9.56)\end{aligned}$ & 0.642 & -2.682 & $\begin{array}{r}-1.956 \\
(4) \\
\end{array}$ & $\begin{array}{c}-0.091 \\
(-0.671)\end{array}$ & 42.36 & 1 \\
\hline
\end{tabular}


Table A3 continued: Cointegration of Lending Rates

\begin{tabular}{|c|c|c|c|c|c|c|c|c|c|c|c|c|c|c|c|c|c|c|}
\hline \multirow[t]{3}{*}{ Country } & \multirow[t]{3}{*}{ period } & \multicolumn{9}{|c|}{ nominal lending rates } & \multicolumn{8}{|c|}{ real lending rates } \\
\hline & & \multirow{2}{*}{\multicolumn{3}{|c|}{$\begin{array}{l}\text { cointegrating vector } \\
\text { (t-statistics) }\end{array}$}} & \multirow[t]{2}{*}{ DW } & \multirow[t]{2}{*}{ DF } & \multirow{2}{*}{$\begin{array}{r}\text { ADF } \\
(\mathrm{k})\end{array}$} & \multicolumn{3}{|c|}{ ECM } & \multirow{2}{*}{\multicolumn{2}{|c|}{$\begin{array}{l}\text { cointegrating vector } \\
\text { (t-statistics) }\end{array}$}} & \multirow[t]{2}{*}{ DW } & \multirow[t]{2}{*}{ DF } & \multirow{2}{*}{$\begin{array}{r}\mathrm{ADF} \\
(\mathrm{k})\end{array}$} & \multicolumn{3}{|c|}{ ECM } \\
\hline & & & & & & & & $\begin{array}{l}\text { ECT } \\
\text { (t-stat.) }\end{array}$ & AIC & $\begin{array}{r}\text { no. of } \\
\text { lags }\end{array}$ & & & & & & $\begin{array}{c}\text { ECT } \\
\text { (t-stat.) }\end{array}$ & AIC & $\begin{array}{r}\text { no. of } \\
\text { lags }\end{array}$ \\
\hline \multirow[t]{3}{*}{ Austria } & full & $\mathrm{L}_{\text {AUS }}$ & $\begin{aligned}= & 0.80 \\
& (3.12)\end{aligned}$ & $+\begin{array}{l}0.60 \mathrm{~L}_{\mathrm{EU}} \\
(27.26)\end{array}$ & 0.155 & -2.140 & $\begin{array}{r}-2.581 \\
(2,3)\end{array}$ & $\begin{array}{l}-1.778 \\
(-3.842)\end{array}$ & -4.29 & 5 & $\mathrm{~L}_{\mathrm{AUS}}$ & $=\underset{(3.50)}{1.00}+0.62 \mathrm{~L}_{\mathrm{EU}}$ & 0.504 & -3.436 & $\begin{array}{r}-2.608 \\
(1)\end{array}$ & $\begin{array}{c}-0.197 \\
(-2.501)\end{array}$ & 166.46 & 0 \\
\hline & pre-EMU & $\mathrm{L}_{\mathrm{AUS}}$ & $\begin{array}{r}=1.70 \\
(4.79)\end{array}$ & $+\begin{array}{l}0.60 \mathrm{~L}_{\mathrm{EU}} \\
(18.74)\end{array}$ & 0.231 & -2.793 & & $\begin{array}{c}-0.141 \\
(-1.591)\end{array}$ & -12.38 & 3 & $\mathrm{~L}_{\mathrm{AUS}}$ & $=\begin{array}{c}3.82+0.32 \mathrm{~L}_{\mathrm{EU}} \\
(6.99) \\
(5.57)\end{array}$ & 0.678 & -3.115 & & $\begin{array}{l}-0.292 \\
(-2.369)\end{array}$ & 57.78 & 0 \\
\hline & EMU & $\mathrm{L}_{\mathrm{AUS}}$ & $\begin{aligned}= & -6.52 \\
& (-7.79)\end{aligned}$ & $\begin{aligned}+ & 1.47 \mathrm{~L}_{\mathrm{EU}} \\
& (16.22)\end{aligned}$ & 0.295 & -1.372 & & $\begin{array}{c}0.057 \\
(0.496)\end{array}$ & -27.32 & 1 & $\mathrm{~L}_{\mathrm{AUS}}$ & $=\begin{aligned} &-0.86+0.86 \mathrm{~L}_{\mathrm{EU}} \\
&(-1.10) \\
&(8.11)\end{aligned}$ & 0.737 & -2.964 & $\begin{array}{l}-3.593 \\
(1,3,4)\end{array}$ & $\begin{array}{c}-0.428 \\
(-3.362)\end{array}$ & 43.37 & 5 \\
\hline \multirow[t]{3}{*}{ Belgium } & full & $\mathrm{L}_{\mathrm{BEL}}$ & $\begin{aligned}= & -1.05 \\
& (-1.48)\end{aligned}$ & $+\begin{array}{l}0.86 \mathrm{~L}_{\mathrm{EU}} \\
(12.43)\end{array}$ & 0.240 & -3.218 & & $\begin{array}{c}-0.177 \\
(-3.094)\end{array}$ & 221.03 & 1 & $\mathrm{~L}_{\mathrm{BEL}}$ & $=\frac{-2.71}{(-3.88)}+\frac{1.03 \mathrm{~L}_{\mathrm{EU}}}{(12.49)}$ & 0.278 & -3.282 & & $\begin{array}{l}-0.119 \\
(-2.144)\end{array}$ & 260.70 & 0 \\
\hline & pre-EMU & $\mathrm{L}_{\mathrm{BEL}}$ & $\begin{aligned}= & -4.58 \\
& (-3.71)\end{aligned}$ & $\begin{array}{l}+0.16 \mathrm{~L}_{\mathrm{EU}} \\
(10.41)\end{array}$ & 0.331 & -2.547 & & $\begin{array}{c}-0.224 \\
(-2.537)\end{array}$ & 117.84 & 1 & $\mathrm{~L}_{\mathrm{BEL}}$ & $=\begin{array}{l}-9.21+1.70 \mathrm{~L}_{\mathrm{EU}} \\
(-4.63) \\
(8.07)\end{array}$ & 0.380 & -2.575 & & $\begin{array}{l}-0.085 \\
(-1.075)\end{array}$ & 134.17 & 0 \\
\hline & EMU & $\mathrm{L}_{\mathrm{BEL}}$ & $\begin{aligned}= & -2.37 \\
& (-1.20)\end{aligned}$ & $\begin{aligned}+ & 1.03 \mathrm{~L}_{\mathrm{EU}} \\
& (4.86)\end{aligned}$ & 0.231 & -2.130 & & $\begin{array}{c}-0.084 \\
(-1.059)\end{array}$ & 27.46 & 1 & $\mathrm{~L}_{\mathrm{BEL}}$ & $=\begin{aligned}-0.13 & +0.70 \mathrm{~L}_{\mathrm{EU}} \\
(-0.16) & (6.22)\end{aligned}$ & 0.641 & -2.640 & & $\begin{array}{l}-0.205 \\
(-1.495)\end{array}$ & 60.53 & 1 \\
\hline \multirow[t]{4}{*}{ Denmark } & full & $\mathrm{L}_{\mathrm{DEN}}$ & $\begin{array}{r}=5.80 \\
(13.13)\end{array}$ & $\begin{aligned}+ & 0.44 \mathrm{~L}_{\mathrm{EU}} \\
& (9.88)\end{aligned}$ & 0.314 & -2.423 & & $\begin{array}{c}-0.214 \\
(-3.565)\end{array}$ & 84.84 & 2 & $\mathrm{~L}_{\mathrm{DEN}}$ & $\begin{array}{c}=3.78+0.53 \mathrm{~L}_{\mathrm{EU}} \\
(6.25) \quad(7.22)\end{array}$ & 0.227 & -2.094 & & $\begin{array}{c}-0.109 \\
(-1.817)\end{array}$ & 164.55 & 2 \\
\hline & pre-EMU & $\mathrm{L}_{\mathrm{DEN}}$ & $\begin{array}{r}=7.01 \\
(13.07)\end{array}$ & $\begin{aligned}+ & 0.33 \mathrm{~L}_{\mathrm{EU}} \\
& (6.44)\end{aligned}$ & 0.210 & -1.292 & & $\begin{array}{c}-0.067 \\
(-0.897)\end{array}$ & -18.17 & 2 & $\mathrm{~L}_{\mathrm{DEN}}$ & $=\begin{array}{c}5.67+0.33 \mathrm{~L}_{\mathrm{EU}} \\
(3.96) \\
(2.10)\end{array}$ & 0.167 & -0.916 & & $\begin{array}{l}-0.050 \\
(-0.642)\end{array}$ & 50.99 & 0 \\
\hline & EMU & $\mathrm{L}_{\mathrm{DEN}}$ & $\begin{aligned}= & -4.88 \\
& (-4.21)\end{aligned}$ & $+\underset{(12.69)}{1.61 \mathrm{~L}_{\mathrm{EU}}}$ & 0.664 & -2.637 & $\begin{array}{r}-2.545 \\
(3)\end{array}$ & $\begin{array}{c}-0.119 \\
(-0.838)\end{array}$ & 27.03 & 1 & $\mathrm{~L}_{\mathrm{DEN}}$ & $=\begin{array}{c}7.85-0.05 \mathrm{~L}_{\mathrm{EU}} \\
(5.11) \quad(-0.23)\end{array}$ & 0.322 & -1.925 & $\begin{array}{r}-2.030 \\
(3)\end{array}$ & $\begin{array}{l}-0.177 \\
(-1.935)\end{array}$ & 66.94 & 0 \\
\hline & $\begin{array}{l}\text { postbreak } \\
\text { EMU }\end{array}$ & & & & & & & & & & $\mathrm{L}_{\mathrm{DEN}}$ & $=\underset{(3.09)}{6.67}+\begin{array}{l}0.17 \mathrm{~L}_{\mathrm{EU}} \\
(0.55)\end{array}$ & 0.829 & -2.781 & & $\begin{array}{l}-0.488 \\
(-2.111)\end{array}$ & 32.34 & 2 \\
\hline \multirow[t]{4}{*}{ Finland } & full & $\mathrm{L}_{\mathrm{FIN}}$ & $\begin{aligned}= & 1.22 \\
& (2.82)\end{aligned}$ & $+\begin{array}{l}0.82 \mathrm{~L}_{\mathrm{EU}} \\
(19.17)\end{array}$ & 0.388 & -3.092 & & $\begin{array}{c}-0.132 \\
(-1.913)\end{array}$ & 191.93 & 0 & $\mathrm{~L}_{\mathrm{FIN}}$ & $\begin{array}{c}=-5.30+1.27 \mathrm{~L}_{\mathrm{EU}} \\
(-12.31)\end{array}$ & 0.466 & -3.344 & & $\begin{array}{l}-0.129 \\
(-1.798)\end{array}$ & 221.58 & 1 \\
\hline & pre-EMU & $\mathrm{L}_{\mathrm{FIN}}$ & $\begin{aligned}= & -1.95 \\
& (-3.14)\end{aligned}$ & $+\begin{array}{c}0.87 \mathrm{~L}_{\mathrm{EU}} \\
(15.42)\end{array}$ & 0.737 & -3.325 & & $\begin{array}{c}-0.312 \\
(-2.587)\end{array}$ & 96.89 & 0 & $\mathrm{~L}_{\mathrm{FIN}}$ & $=-9.46+1.71 \mathrm{~L}_{\mathrm{EU}}$ & 1.091 & -4.005 & $\begin{array}{r}-4.163 \\
(1)\end{array}$ & $\begin{array}{l}-0.531 \\
(-2.647)\end{array}$ & 105.32 & 5 \\
\hline & EMU & $\mathrm{L}_{\mathrm{FIN}}$ & $\begin{aligned}= & -10.79 \\
& (-5.92)\end{aligned}$ & $\begin{aligned}+ & 1.87 \mathrm{~L}_{\mathrm{EU}} \\
& (9.44)\end{aligned}$ & 0.182 & -1.034 & $\begin{array}{r}-1.527 \\
(4)\end{array}$ & $\begin{array}{c}0.146 \\
(1.822)\end{array}$ & 28.24 & 0 & $\mathrm{~L}_{\mathrm{FIN}}$ & $=\begin{array}{l}-0.60 \\
(-0.59)\end{array}$ & 0.275 & -1.902 & $\begin{array}{r}-1.847 \\
(3)\end{array}$ & $\begin{array}{l}-0.145 \\
(-1.372)\end{array}$ & 60.68 & 0 \\
\hline & $\begin{array}{l}\text { postbreak } \\
\text { EMU }\end{array}$ & $\mathrm{L}_{\mathrm{FIN}}$ & $\begin{aligned}= & -22.63 \\
& (-4.95)\end{aligned}$ & $\begin{aligned}+ & 4.57 \mathrm{~L}_{\mathrm{EU}} \\
& (6.42)\end{aligned}$ & 0.257 & -2.018 & & $\begin{array}{c}0.227 \\
(2.168)\end{array}$ & 15.14 & 0 & & & & & & & & \\
\hline \multirow[t]{3}{*}{ France } & full & $\mathrm{L}_{\mathrm{FRA}}$ & $\begin{aligned}= & -0.33 \\
& (-1.33)\end{aligned}$ & $\begin{array}{c}+0.95 \mathrm{~L}_{\mathrm{EU}} \\
(39.54)\end{array}$ & 0.388 & -2.904 & $\begin{array}{r}-3.359 \\
(3)\end{array}$ & $\begin{array}{l}-0.198 \\
(-4.087)\end{array}$ & 31.07 & 1 & $\mathrm{~L}_{\mathrm{FRA}}$ & $=\underset{(2.81)}{0.80}+0.86 \mathrm{~L}_{\mathrm{EU}}$ & 0.470 & -2.998 & $\begin{array}{r}-3.731 \\
(3)\end{array}$ & $\begin{array}{c}-0.175 \\
(-1.862)\end{array}$ & 184.42 & 1 \\
\hline & pre-EMU & $\mathrm{L}_{\mathrm{FRA}}$ & $=\begin{array}{c}0.79 \\
(2.18)\end{array}$ & $+\begin{array}{l}0.86 \mathrm{~L}_{\mathrm{EU}} \\
(26.40)\end{array}$ & 0.541 & -2.686 & $\begin{array}{r}-3.176 \\
(3)\end{array}$ & $\begin{array}{l}-0.320 \\
(-3.816)\end{array}$ & 7.39 & 2 & $\mathrm{~L}_{\mathrm{FRA}}$ & $=\underset{(2.83)}{1.72}+0.76 \mathrm{~L}_{\mathrm{EU}}$ & 0.586 & -2.997 & $\begin{array}{r}-3.461 \\
(3)\end{array}$ & $\begin{array}{l}-0.306 \\
(-2.377)\end{array}$ & 78.50 & 1 \\
\hline & EMU & $\mathrm{L}_{\mathrm{FRA}}$ & $\begin{array}{r}=2.82 \\
(4.26)\end{array}$ & $\begin{aligned} & 0.60 \mathrm{~L}_{\mathrm{EU}} \\
& (8.59)\end{aligned}$ & 0.500 & -1.713 & & $\begin{array}{c}-0.196 \\
(-1.994)\end{array}$ & -34.18 & 1 & $\mathrm{~L}_{\mathrm{FRA}}$ & $=\begin{array}{l}0.65 \\
(0.68)\end{array}$ & 0.837 & -1.399 & $\begin{array}{r}-1.343 \\
(3,4)\end{array}$ & $\begin{array}{l}-0.114 \\
(-0.954)\end{array}$ & 59.67 & 1 \\
\hline real & $\begin{array}{l}\text { postbreak } \\
\text { EMU }\end{array}$ & & & & & & & & & & $\mathrm{L}_{\mathrm{FRA}}$ & $=\begin{array}{c}3.34 \\
(0.97)\end{array}+\begin{array}{l}0.44 \mathrm{~L}_{\mathrm{EU}} \\
(0.92)\end{array}$ & 0.924 & -1.910 & & $\begin{array}{l}-0.554 \\
(-1.604)\end{array}$ & 25.79 & 0 \\
\hline \multirow[t]{4}{*}{ Germany } & full & $\mathrm{L}_{\mathrm{GER}}$ & $=\begin{array}{r}6.49 \\
(53.56)\end{array}$ & $+\underset{(37.70)}{0.48 \mathrm{~L}_{\mathrm{EU}}}$ & 0.216 & -2.880 & & $\begin{array}{c}-0.009 \\
(-2.089)\end{array}$ & -55.68 & 2 & $\mathrm{~L}_{\mathrm{GER}}$ & $=\underset{(18.61)}{4.95}+\underset{(17.57)}{0.62 \mathrm{~L}_{\mathrm{EU}}}$ & 0.275 & -2.207 & & $\begin{array}{l}-0.182 \\
(-2.778)\end{array}$ & 168.49 & 2 \\
\hline & pre-EMU & $\mathrm{L}_{\mathrm{GER}}$ & $\begin{array}{c}=6.16 \\
(35.01)\end{array}$ & $\begin{array}{c}+0.51 \mathrm{~L}_{\mathrm{EU}} \\
\quad(30.38)\end{array}$ & 0.358 & -3.204 & & $\begin{array}{c}-0.068 \\
(-0.877)\end{array}$ & -37.38 & 2 & $\mathrm{~L}_{\mathrm{GER}}$ & $=\underset{(11.42)}{5.84}+0.52 \mathrm{~L}_{\mathrm{EU}}$ & 0.301 & -1.447 & & $\begin{array}{l}-0.107 \\
(-1.239)\end{array}$ & 44.37 & 2 \\
\hline & EMU & $\mathrm{L}_{\mathrm{GER}}$ & $=\begin{array}{c}5.67 \\
(8.30)\end{array}$ & $\begin{aligned}+ & 0.59 \mathrm{~L}_{\mathrm{EU}} \\
& (7.05)\end{aligned}$ & 0.152 & -0.632 & & $\begin{array}{c}-0.057 \\
(-1.230)\end{array}$ & -81.12 & 2 & $\mathrm{~L}_{\mathrm{GER}}$ & $=\underset{(2.52)}{2.76}+\frac{0.97 \mathrm{~L}_{\mathrm{EU}}}{(5.58)}$ & 0.256 & -1.071 & & $\begin{array}{l}-0.161 \\
(-1.360)\end{array}$ & 79.67 & 0 \\
\hline & $\begin{array}{l}\text { postbreak } \\
\text { EMU }\end{array}$ & $\mathrm{L}_{\mathrm{GER}}$ & $=\begin{array}{r}9.86 \\
(25.77)\end{array}$ & $\begin{aligned}+ & 0.10 \mathrm{~L}_{\mathrm{EU}} \\
& (2.25)\end{aligned}$ & 0.581 & -2.870 & & $\begin{array}{l}-0.411 \\
(-4.322)\end{array}$ & -80.58 & 3 & $\mathrm{~L}_{\mathrm{GER}}$ & $=\underset{(4.99)}{7.29}+\frac{0.20 \mathrm{~L}_{\mathrm{EU}}}{(0.80)}$ & 0.600 & -2.209 & & $\begin{array}{l}-0.352 \\
(-2.233)\end{array}$ & 57.86 & 0 \\
\hline \multirow[t]{2}{*}{ Greece } & EMU & $\mathrm{L}_{\mathrm{GRE}}$ & $\begin{array}{r}=101.93 \\
(8.67)\end{array}$ & $\begin{array}{l}-9.39 \mathrm{~L}_{\mathrm{EU}} \\
(-7.30)\end{array}$ & 0.109 & -0.446 & & $\begin{array}{l}-0.079 \\
(-2.383)\end{array}$ & 97.06 & 0 & $\mathrm{~L}_{\mathrm{GRE}}$ & $\begin{aligned}= & -29.22+5.85 \mathrm{~L}_{\mathrm{EU}} \\
(-3.44) & (5.00)\end{aligned}$ & 0.178 & -1.221 & $\begin{array}{r}-0.455 \\
(4)\end{array}$ & $\begin{array}{l}-0.068 \\
(-2.082)\end{array}$ & 127.57 & 1 \\
\hline & $\begin{array}{l}\text { postbreak } \\
\text { EMU }\end{array}$ & $\mathrm{L}_{\mathrm{GRE}}$ & $\begin{aligned}= & -17.31 \\
& (-2.80)\end{aligned}$ & $\begin{aligned}+ & 3.16 \mathrm{~L}_{\mathrm{EU}} \\
& (4.76)\end{aligned}$ & 0.609 & -2.480 & & $\begin{array}{l}-0.256 \\
(-1.806)\end{array}$ & 11.02 & 1 & $\mathrm{~L}_{\mathrm{GRE}}$ & $=\begin{array}{c}5.97+0.50 \mathrm{~L}_{\mathrm{EU}} \\
(0.57)\end{array}$ & 0.157 & -4.116 & & $\begin{array}{l}-0.271 \\
(-4.504)\end{array}$ & 64.96 & 0 \\
\hline
\end{tabular}


Table A3 continued: Cointegration of Lending Rates

\begin{tabular}{|c|c|c|c|c|c|c|c|c|c|c|c|c|c|c|c|c|c|}
\hline \multirow[t]{3}{*}{ Country } & \multirow[t]{3}{*}{ period } & \multicolumn{8}{|c|}{ nominal lending rates } & \multicolumn{8}{|c|}{ real lending rates } \\
\hline & & \multirow{2}{*}{\multicolumn{2}{|c|}{$\begin{array}{l}\text { cointegrating vector } \\
\text { (t-statistics) }\end{array}$}} & \multirow[t]{2}{*}{ DW } & \multirow[t]{2}{*}{ DF } & \multirow{2}{*}{$\begin{array}{r}\mathrm{ADF} \\
(\mathrm{k})\end{array}$} & \multicolumn{3}{|c|}{ ECM } & \multirow{2}{*}{\multicolumn{2}{|c|}{$\begin{array}{l}\text { cointegrating vector } \\
\text { (t-statistics) }\end{array}$}} & \multirow[t]{2}{*}{ DW } & \multirow[t]{2}{*}{ DF } & \multirow{2}{*}{$\begin{array}{r}\mathrm{ADF} \\
(\mathrm{k})\end{array}$} & \multicolumn{3}{|c|}{ ECM } \\
\hline & & & & & & & $\begin{array}{c}\text { ECT } \\
\text { (t-stat.) }\end{array}$ & AIC & $\begin{array}{r}\text { no. of } \\
\text { lags }\end{array}$ & & & & & & $\begin{array}{c}\text { ECT } \\
\text { (t-stat.) }\end{array}$ & AIC & $\begin{array}{r}\text { no. of } \\
\text { lags }\end{array}$ \\
\hline \multirow[t]{3}{*}{ Portugal } & full & $\begin{array}{ll}\mathrm{L}_{\mathrm{POR}} \\
\mathrm{n}\end{array}$ & $\begin{array}{c}=-12.86+2.50 \mathrm{~L}_{\mathrm{EU}} \\
(-14.72) \quad(28.70)\end{array}$ & 0.701 & -4.380 & & $\begin{array}{l}-0.384 \\
(-4.792)\end{array}$ & 331.33 & 0 & $\mathrm{~L}_{\mathrm{POR}}$ & $\begin{aligned}= & -9.43+2.22 \mathrm{~L}_{\mathrm{EU}} \\
& (-7.34) \quad(14.48)\end{aligned}$ & 0.377 & -2.956 & & $\begin{array}{l}-0.134 \\
(-2.434)\end{array}$ & 360.87 & 0 \\
\hline & pre-EMU & $\mathrm{L}_{\mathrm{POR}}$ & $\begin{aligned}= & -11.75+2.41 \mathrm{~L}_{\mathrm{EU}} \\
& (-7.31) \quad(16.15)\end{aligned}$ & 0.604 & -2.898 & & $\begin{array}{c}-0.309 \\
(-2.948)\end{array}$ & 166.42 & 0 & $\mathrm{~L}_{\mathrm{POR}}$ & $\begin{aligned} &=-13.52+2.68 \mathrm{~L}_{\mathrm{EU}} \\
&(-3.79) \\
&(6.93)\end{aligned}$ & 0.273 & -1.430 & & $\begin{array}{l}-0.080 \\
(-1.072)\end{array}$ & 177.57 & 1 \\
\hline & EMU & $\mathrm{L}_{\mathrm{POR}}$ & $=\frac{-4.31}{(-1.59)}+\frac{1.54 \mathrm{~L}_{\mathrm{EU}}}{(5.21)}$ & 1.417 & -4.648 & & $\begin{array}{l}-0.767 \\
(-4.992)\end{array}$ & 114.24 & 0 & $\mathrm{~L}_{\mathrm{POR}}$ & $=\begin{array}{c}4.75 \\
(2.99)\end{array}$ & 1.193 & -4.050 & $\begin{array}{r}-2.387 \\
(1)\end{array}$ & $\begin{array}{l}-0.443 \\
(-2.781)\end{array}$ & 114.89 & 2 \\
\hline \multirow[t]{4}{*}{ Spain } & full & $\mathrm{L}_{\mathrm{SPA}}$ & $\begin{array}{c}=-13.72+2.35 \mathrm{~L}_{\mathrm{EU}} \\
(-23.79) \quad(41.23)\end{array}$ & 0.456 & -4.073 & $\begin{array}{r}-3.786 \\
(3)\end{array}$ & $\begin{array}{l}-0.285 \\
(-4.226)\end{array}$ & 208.17 & 0 & $\mathrm{~L}_{\mathrm{SPA}}$ & $\begin{aligned}= & -7.18+1.67 \mathrm{~L}_{\mathrm{EU}} \\
& (-8.98) \quad(17.97)\end{aligned}$ & 0.365 & -3.084 & & $\begin{array}{l}-0.111 \\
(-2.096)\end{array}$ & 246.93 & 2 \\
\hline & pre-EMU & $\mathrm{L}_{\mathrm{SPA}}$ & $\begin{array}{c}=-13.26+2.32 \mathrm{~L}_{\mathrm{EU}} \\
(-12.54) \\
(23.55)\end{array}$ & 0.292 & -2.570 & $\begin{array}{r}-2.253 \\
(3)\end{array}$ & $\begin{array}{l}-0.338 \\
(-5.702)\end{array}$ & 56.09 & 3 & $\mathrm{~L}_{\mathrm{SPA}}$ & 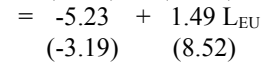 & 0.255 & -1.538 & & $\begin{array}{l}-0.173 \\
(-2.462)\end{array}$ & 95.63 & 2 \\
\hline & EMU & $\mathrm{L}_{\mathrm{SPA}}$ & $=\begin{array}{l}-7.24 \\
(-4.50)\end{array}$ & 1.221 & -4.323 & & $\begin{array}{c}-0.517 \\
(-3.226)\end{array}$ & 68.38 & 0 & $\mathrm{~L}_{\mathrm{SPA}}$ & $=\underset{(1.96)}{2.73}+\begin{array}{l}0.32 \mathrm{~L}_{\mathrm{EU}} \\
(1.79)\end{array}$ & 0.736 & -3.287 & & $\begin{array}{c}-0.434 \\
(-3.817)\end{array}$ & 93.02 & 2 \\
\hline & $\begin{array}{l}\text { postbreak } \\
\text { EMU }\end{array}$ & $\mathrm{L}_{\mathrm{SPA}}$ & $=\begin{array}{l}-2.58+1.16 \mathrm{~L}_{\mathrm{EU}} \\
(-0.94)\end{array}$ & 1.503 & -3.961 & $\begin{array}{r}-2.289 \\
(2,4)\end{array}$ & $\begin{array}{c}-0.803 \\
(-4.528)\end{array}$ & 34.56 & 1 & & & & & & & & \\
\hline \multirow[t]{3}{*}{ Sweden } & full & $\mathrm{L}_{\mathrm{SWE}}$ & $\begin{array}{c}=-5.89+1.37 \mathrm{~L}_{\mathrm{EU}} \\
(-12.16) \quad(28.16)\end{array}$ & 0.204 & -1.988 & $\begin{array}{r}-3.040 \\
(3)\end{array}$ & $\begin{array}{l}-0.086 \\
(-2.119)\end{array}$ & 28.83 & 1 & $\mathrm{~L}_{\mathrm{SPA}}$ & 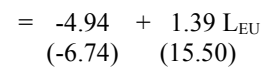 & 0.231 & -1.396 & $\begin{array}{r}-2.029 \\
(3)\end{array}$ & $\begin{array}{l}-0.153 \\
(-2.728)\end{array}$ & 165.04 & 2 \\
\hline & pre-EMU & $\mathrm{L}_{\mathrm{SWE}}$ & 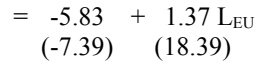 & 0.250 & -1.471 & $\begin{array}{r}-2.423 \\
(3)\end{array}$ & $\begin{array}{c}-0.152 \\
(-2.310)\end{array}$ & 9.59 & 1 & $\mathrm{~L}_{\mathrm{SWE}}$ & $\begin{aligned} &=-11.64+2.10 \mathrm{~L}_{\mathrm{EU}} \\
&(-6.79) \\
&(11.08)\end{aligned}$ & 0.293 & -1.705 & & $\begin{array}{l}-0.200 \\
(-2.157)\end{array}$ & 79.96 & 1 \\
\hline & EMU & $\mathrm{L}_{\mathrm{SWE}}$ & $=\underset{(5.45)}{3.36}+\begin{array}{l}0.35 \mathrm{~L}_{\mathrm{EU}} \\
(5.18)\end{array}$ & 0.418 & -1.896 & $\begin{array}{r}-3.102 \\
(3,4)\end{array}$ & $\begin{array}{l}-0.267 \\
(-2.740)\end{array}$ & -55.62 & 2 & $\mathrm{~L}_{\mathrm{SWE}}$ & $\begin{aligned} &=-2.85+1.10 \mathrm{~L}_{\mathrm{EU}} \\
&(-1.77) \\
&(4.98)\end{aligned}$ & 0.319 & -0.147 & & $\begin{array}{c}0.060 \\
(0.622)\end{array}$ & 48.38 & 2 \\
\hline \multirow[t]{3}{*}{ UK } & full & $\mathrm{L}_{\mathrm{UKD}}$ & $=\begin{array}{c}4.75+1.26 \mathrm{~L}_{\mathrm{EU}} \\
(6.18) \quad(16.60)\end{array}$ & 0.166 & -2.102 & & $\begin{array}{c}-0.143 \\
(-3.468)\end{array}$ & 200.69 & 0 & $\mathrm{~L}_{\mathrm{UKD}}$ & $=\underset{(20.10)}{8.68}+\underset{(16.44)}{0.84 \mathrm{~L}_{\mathrm{EU}}}$ & 0.472 & -3.581 & & $\begin{array}{c}-0.241 \\
(-3.404)\end{array}$ & 213.68 & 1 \\
\hline & pre-EMU & $\mathrm{L}_{\mathrm{UKD}}$ & $=\underset{(16.41)}{10.65}+0.76 \mathrm{~L}_{\mathrm{EU}}$ & 0.336 & -2.056 & & $\begin{array}{l}-0.203 \\
(-2.387)\end{array}$ & 64.32 & 1 & $\mathrm{~L}_{\mathrm{UKD}}$ & $=\frac{13.19}{(15.87)}+\begin{array}{l}0.38 \mathrm{~L}_{\mathrm{EU}} \\
(4.23)\end{array}$ & 0.503 & -2.697 & & $\begin{array}{c}-0.396 \\
(-3.611)\end{array}$ & 77.37 & 2 \\
\hline & EMU & $\mathrm{L}_{\text {UKD }}$ & $\begin{aligned}= & 17.00-0.14 \mathrm{~L}_{\mathrm{EU}} \\
(9.63) & (-0.72)\end{aligned}$ & 0.741 & -3.384 & & $\begin{array}{c}-0.356 \\
(-3.086)\end{array}$ & 56.79 & 1 & $\mathrm{~L}_{\mathrm{UKD}}$ & $=\begin{array}{l}12.03 \\
(14.35)\end{array}+\begin{array}{l}0.35 \mathrm{~L}_{\mathrm{EU}} \\
(3.04)\end{array}$ & 0.877 & -3.236 & & $\begin{array}{c}-0.465 \\
(-3.423)\end{array}$ & 63.32 & 1 \\
\hline
\end{tabular}


Table A3 continued: Cointegration of Lending Rates

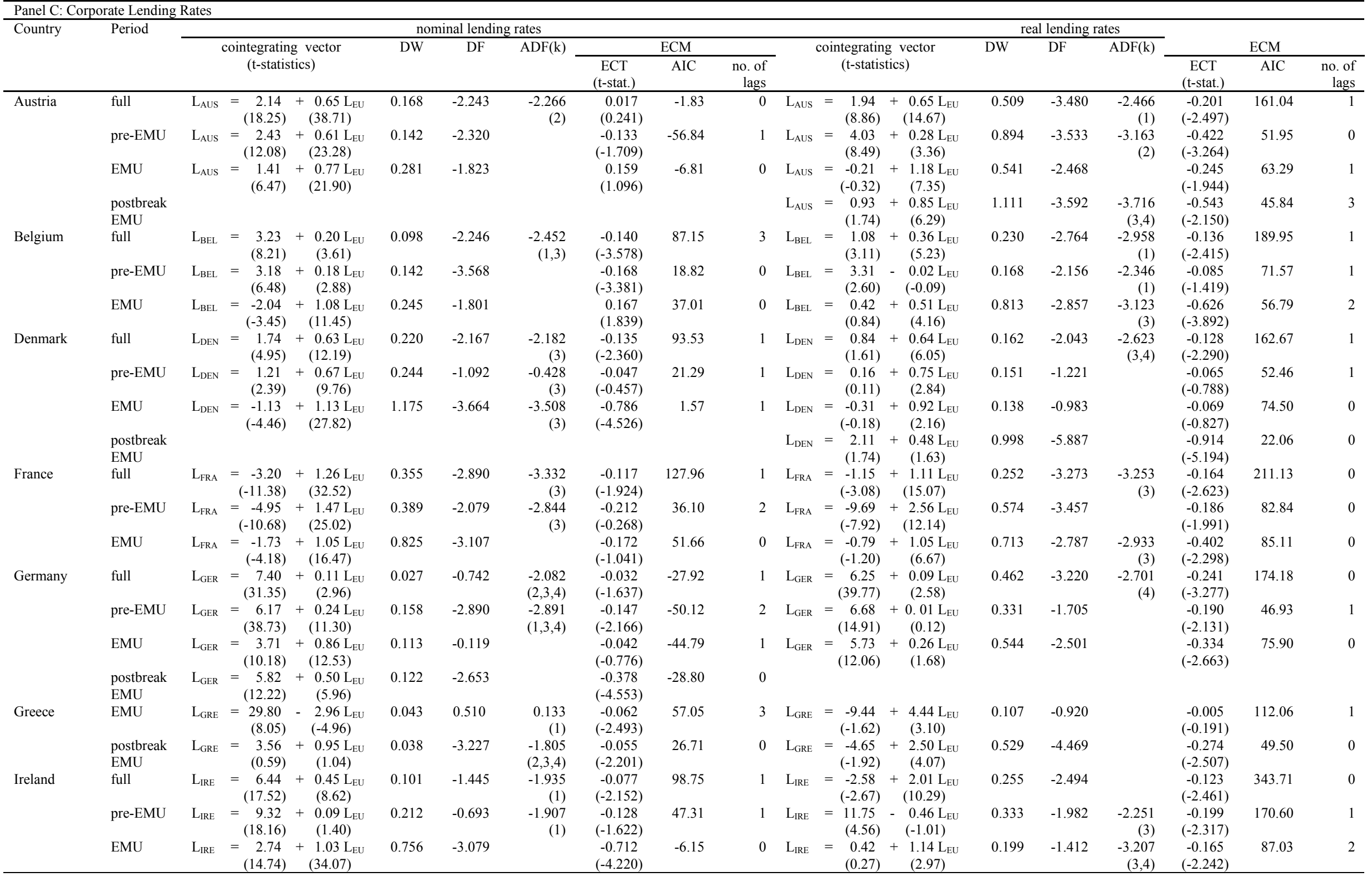


Table A3 continued: Cointegration of Lending Rates

\begin{tabular}{|c|c|c|c|c|c|c|c|c|c|c|c|c|c|c|c|c|c|}
\hline \multirow[t]{3}{*}{ Country } & \multirow[t]{3}{*}{ period } & \multicolumn{8}{|c|}{ nominal lending rates } & \multicolumn{8}{|c|}{ real lending rates } \\
\hline & & \multirow{2}{*}{\multicolumn{2}{|c|}{$\begin{array}{c}\text { cointegrating vector } \\
\text { (t-statistics) }\end{array}$}} & \multirow[t]{2}{*}{ DW } & \multirow[t]{2}{*}{ DF } & \multirow{2}{*}{$\begin{array}{r}\text { ADF } \\
(\mathrm{k})\end{array}$} & \multicolumn{3}{|c|}{ ECM } & \multirow{2}{*}{\multicolumn{2}{|c|}{$\begin{array}{l}\text { cointegrating vector } \\
\text { (t-statistics) }\end{array}$}} & \multirow[t]{2}{*}{ DW } & \multirow[t]{2}{*}{$\mathrm{DF}$} & \multirow{2}{*}{$\begin{array}{r}\mathrm{ADF} \\
(\mathrm{k})\end{array}$} & \multicolumn{3}{|c|}{ ECM } \\
\hline & & & & & & & $\begin{array}{c}\text { ECT } \\
\text { (t-stat.) }\end{array}$ & AIC & $\begin{array}{r}\text { no. of } \\
\text { lags }\end{array}$ & & & & & & $\begin{array}{c}\text { ECT } \\
\text { (t-stat.) }\end{array}$ & AIC & $\begin{array}{r}\text { no. of } \\
\text { lags }\end{array}$ \\
\hline \multirow[t]{3}{*}{ Italy } & full & $\mathrm{L}_{\text {ITA }}$ & $\begin{array}{c}=-7.73+2.47 \mathrm{~L}_{\mathrm{EU}} \\
(-5.41) \\
(11.39)\end{array}$ & 0.022 & -0.640 & $\begin{array}{r}-1.281 \\
(2,3)\end{array}$ & $\begin{array}{l}-0.021 \\
(-2.718)\end{array}$ & -7.02 & 1 & $\mathrm{~L}_{\text {ITA }}$ & $\begin{aligned}= & -3.50+1.95 \mathrm{~L}_{\mathrm{EU}} \\
(-4.27) & (11.32)\end{aligned}$ & 0.158 & -1.996 & & $\begin{array}{l}-0.040 \\
(-1.744)\end{array}$ & 152.87 & 2 \\
\hline & pre-EMU & $\mathrm{L}_{\text {ITA }}$ & $=\begin{aligned}-4.23 & +2.14 \mathrm{~L}_{\mathrm{EU}} \\
(-4.93) & (17.29)\end{aligned}$ & 0.086 & -1.812 & $\begin{array}{r}-1.040 \\
(3)\end{array}$ & $\begin{array}{l}-0.016 \\
(-0.628)\end{array}$ & -16.87 & 0 & $\mathrm{~L}_{\mathrm{ITA}}$ & $=\underset{(3.96)}{5.72}+\begin{array}{l}0.29 \mathrm{~L}_{\mathrm{EU}} \\
(1.07)\end{array}$ & 0.049 & 1.041 & $\begin{array}{r}-0.063 \\
(3)\end{array}$ & $\begin{array}{c}0.018 \\
(0.536)\end{array}$ & 37.45 & 2 \\
\hline & EMU & $\mathrm{L}_{\mathrm{ITA}}$ & $=\frac{1.36}{(4.61) \quad(16.15)}$ & 0.272 & -4.019 & & $\begin{array}{c}-0.321 \\
(-4.367)\end{array}$ & -47.13 & 1 & $\mathrm{~L}_{\text {ITA }}$ & $=\underset{(1.38)}{1.03}+\frac{0.69 \mathrm{~L}_{\mathrm{EU}}}{(3.82)}$ & 0.500 & -2.456 & & $\begin{array}{l}-0.290 \\
(-2.821)\end{array}$ & 62.48 & 0 \\
\hline \multirow[t]{4}{*}{ Netherlands } & full & $\mathrm{L}_{\mathrm{NET}}$ & $=\begin{array}{l}4.02-0.01 \mathrm{~L}_{\mathrm{EU}} \\
(8.08)(-0.16)\end{array}$ & 0.062 & -1.220 & $\begin{array}{r}-2.537 \\
(3,4)\end{array}$ & $\begin{array}{l}-0.059 \\
(-2.359)\end{array}$ & 94.74 & 1 & $\mathrm{~L}_{\mathrm{NET}}$ & $=\frac{-1.18}{(-2.12)}+\frac{0.50 \mathrm{~L}_{\mathrm{EU}}}{(4.87)}$ & 0.180 & -1.504 & & $\begin{array}{l}-0.053 \\
(-1.143)\end{array}$ & 212.84 & 4 \\
\hline & pre-EMU & $\mathrm{L}_{\mathrm{NET}}$ & $=\underset{(5.77)}{2.89}+\begin{array}{l}0.09 \mathrm{~L}_{\mathrm{EU}} \\
(1.41)\end{array}$ & 0.060 & -2.064 & & $\begin{array}{l}-0.070 \\
(-1.959)\end{array}$ & -6.75 & 0 & $\mathrm{~L}_{\mathrm{NET}}$ & $=\begin{array}{l}-0.63 \\
(-0.74)\end{array}+\frac{0.41 \mathrm{~L}_{\mathrm{EU}}}{(2.95)}$ & 0.416 & -2.036 & & $\begin{array}{l}-0.181 \\
(-1.696)\end{array}$ & 89.03 & 0 \\
\hline & EMU & $\mathrm{L}_{\mathrm{NET}}$ & $=-4.42+1.37 \mathrm{~L}_{\mathrm{EU}}$ & 0.942 & -2.663 & & $\begin{array}{c}-0.265 \\
(-1.484)\end{array}$ & 44.82 & 1 & $\mathrm{~L}_{\mathrm{NET}}$ & $=\begin{array}{c}-2.37+0.78 \mathrm{~L}_{\mathrm{EU}} \\
(-0.98)\end{array}$ & 0.160 & -0.899 & & $\begin{array}{l}-0.024 \\
(-0.427)\end{array}$ & 89.18 & 2 \\
\hline & $\begin{array}{l}\text { postbreak } \\
\text { EMU }\end{array}$ & & & & & & & & & $\mathrm{L}_{\mathrm{NET}}$ & $=\underset{(-2.54)}{-5.41}+\frac{1.22 \mathrm{~L}_{\mathrm{EU}}}{(2.49)}$ & 0.888 & -4.456 & & $\begin{array}{l}-0.445 \\
(-3.275)\end{array}$ & 35.39 & 0 \\
\hline \multirow[t]{4}{*}{ Portugal } & full & $\mathrm{L}_{\mathrm{POR}}$ & $\begin{array}{c}=-9.30+2.52 \mathrm{~L}_{\mathrm{EU}} \\
(-12.73) \quad(24.07)\end{array}$ & 0.583 & -1.824 & $\begin{array}{r}-1.575 \\
(1,3)\end{array}$ & $\begin{array}{l}-0.138 \\
(-3.739)\end{array}$ & 212.86 & 2 & $\mathrm{~L}_{\mathrm{POR}}$ & $=\frac{-9.97}{(-13.65)}+3.06 \mathrm{~L}_{\mathrm{EU}}$ & 0.418 & -3.096 & & $\begin{array}{l}-0.043 \\
(-0.885)\end{array}$ & 284.77 & 0 \\
\hline & pre-EMU & $\mathrm{L}_{\mathrm{POR}}$ & $=-7.33+2.34 \mathrm{~L}_{\mathrm{EU}}$ & 1.401 & -4.788 & & $\begin{array}{l}-0.717 \\
(-5.032)\end{array}$ & 102.33 & 0 & $\mathrm{~L}_{\mathrm{POR}}$ & $=\frac{-15.82}{(-8.22)}+\frac{4.12 \mathrm{~L}_{\mathrm{EU}}}{(12.04)}$ & 0.504 & -2.018 & $\begin{array}{r}-2.396 \\
(3)\end{array}$ & $\begin{array}{l}-0.178 \\
(-1.893)\end{array}$ & 140.06 & 1 \\
\hline & EMU & $\mathrm{L}_{\mathrm{POR}}$ & $=\underset{(1.85) \quad(11.10)}{0.81}+0.78 \mathrm{~L}_{\mathrm{EU}}$ & 0.702 & -3.543 & & $\begin{array}{l}-0.434 \\
(-3.530)\end{array}$ & 31.81 & 3 & $\mathrm{~L}_{\mathrm{POR}}$ & $=\frac{-0.17}{(-0.12)}+0.65 \mathrm{~L}_{\mathrm{EU}}$ & 0.269 & -1.623 & & $\begin{array}{l}-0.066 \\
(-0.872)\end{array}$ & 88.67 & 0 \\
\hline & $\begin{array}{l}\text { postbreak } \\
\text { EMU }\end{array}$ & $\mathrm{L}_{\mathrm{POR}}$ & $=\underset{(0.46)}{0.16}+0.87 \mathrm{~L}_{\mathrm{EU}}$ & 1.257 & -4.104 & & $\begin{array}{c}-0.660 \\
(-3.443)\end{array}$ & 30.62 & 2 & & & & & & & & \\
\hline \multirow[t]{3}{*}{ Spain } & full & $\mathrm{L}_{\mathrm{SPA}}$ & $=\frac{-7.10}{(-20.23)}+1.89 \mathrm{~L}_{\mathrm{EU}}$ & 0.303 & -2.730 & $\begin{array}{r}-2.176 \\
(1)\end{array}$ & $\begin{array}{l}-0.058 \\
(-0.920)\end{array}$ & 157.78 & 3 & $\mathrm{~L}_{\mathrm{SPA}}$ & $=\frac{-5.08}{(-12.57)}+1.64 \mathrm{~L}_{\mathrm{EU}}$ & 0.494 & -3.687 & & $\begin{array}{l}-0.229 \\
(-3.269)\end{array}$ & 233.74 & 1 \\
\hline & pre-EMU & $\mathrm{L}_{\mathrm{SPA}}$ & $\begin{array}{c}=-8.02+2.03 \mathrm{~L}_{\mathrm{EU}} \\
(-16.63) \\
(32.12)\end{array}$ & 0.354 & -2.511 & & $\begin{array}{l}-0.201 \\
(-2.317)\end{array}$ & 53.03 & 1 & $\mathrm{~L}_{\mathrm{SPA}}$ & $=\begin{array}{l}-5.28+1.69 \mathrm{~L}_{\mathrm{EU}} \\
(-4.76)\end{array}$ & 0.406 & -2.768 & & $\begin{array}{c}-0.241 \\
(-3.064)\end{array}$ & 76.31 & 1 \\
\hline & EMU & $\mathrm{L}_{\mathrm{SPA}}$ & $=\frac{-2.53+1.15 \mathrm{~L}_{\mathrm{EU}}}{(-6.87) \quad(19.93)}$ & 1.500 & -4.793 & & $\begin{array}{c}-0.531 \\
(-2.559)\end{array}$ & 63.15 & 0 & $\mathrm{~L}_{\mathrm{SPA}}$ & $=\begin{array}{l}-1.06 \\
(-1.07)\end{array}+\frac{0.69 \mathrm{~L}_{\mathrm{EU}}}{(2.98)}$ & 0.752 & -2.858 & & $\begin{array}{c}-0.393 \\
(-2.753)\end{array}$ & 104.28 & 0 \\
\hline \multirow[t]{4}{*}{ Sweden } & full & $\mathrm{L}_{\mathrm{SWE}}$ & $\begin{aligned}= & -3.70+1.45 \mathrm{~L}_{\mathrm{EU}} \\
& (-8.03) \quad(22.26)\end{aligned}$ & 0.101 & -1.436 & $\begin{array}{r}-3.092 \\
(3)\end{array}$ & $\begin{array}{l}-0.046 \\
(-1.981)\end{array}$ & 39.70 & 0 & $\mathrm{~L}_{\mathrm{SWE}}$ & $=\frac{-2.38+1.14 \mathrm{~L}_{\mathrm{EU}}}{(-6.61) \quad(15.74)}$ & 0.173 & -1.433 & $\begin{array}{r}-1.790 \\
(3)\end{array}$ & $\begin{array}{l}-0.059 \\
(-1.200)\end{array}$ & 189.83 & 1 \\
\hline & pre-EMU & $\mathrm{L}_{\mathrm{SWE}}$ & 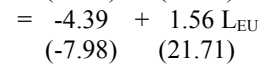 & 0.224 & -1.442 & $\begin{array}{r}-2.507 \\
(3)\end{array}$ & $\begin{array}{c}-0.131 \\
(-3.138)\end{array}$ & 8.69 & 1 & $\mathrm{~L}_{\mathrm{SWE}}$ & $\begin{aligned}= & -9.52+2.74 \mathrm{~L}_{\mathrm{EU}} \\
& (-6.90) \quad(11.26)\end{aligned}$ & 0.284 & -1.616 & & $\begin{array}{c}-0.098 \\
(-1.416)\end{array}$ & 92.25 & 1 \\
\hline & EMU & $\mathrm{L}_{\mathrm{SWE}}$ & $=\underset{(17.94)}{2.82}+\underset{(14.34)}{0.36 \mathrm{~L}_{\mathrm{EU}}}$ & 0.501 & -2.116 & & $\begin{array}{l}-0.185 \\
(-1.257)\end{array}$ & -39.17 & 1 & $\mathrm{~L}_{\mathrm{SWE}}$ & $\begin{aligned}= & -2.16+1.41 \mathrm{~L}_{\mathrm{EU}} \\
& (-1.44) \\
& (3.90)\end{aligned}$ & 0.244 & -0.075 & & $\begin{array}{c}0.314 \\
(2.439)\end{array}$ & 46.79 & 3 \\
\hline & $\begin{array}{l}\text { postbreak } \\
\text { EMU }\end{array}$ & $\mathrm{L}_{\mathrm{SWE}}$ & $=\underset{(17.17)}{2.94}+0.35 \mathrm{~L}_{\mathrm{EU}}$ & 0.515 & -2.426 & $\begin{array}{r}-2.622 \\
(3)\end{array}$ & $\begin{array}{l}-0.162 \\
(-1.003)\end{array}$ & -31.57 & 0 & & & & & & & & \\
\hline
\end{tabular}

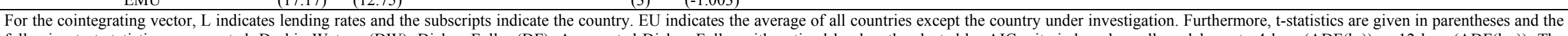

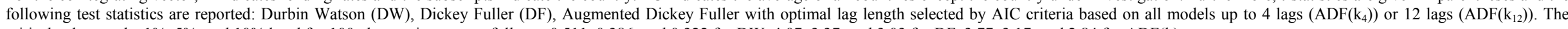
critical values at the $1 \%, 5 \%$, and $10 \%$ level for 100 observations are as follows: $0.511,0.386$, and 0.322 for DW, 4.07, 3.37, and 3.03 for DF, 3.77, 3.17, and 2.84 for ADF(k). 


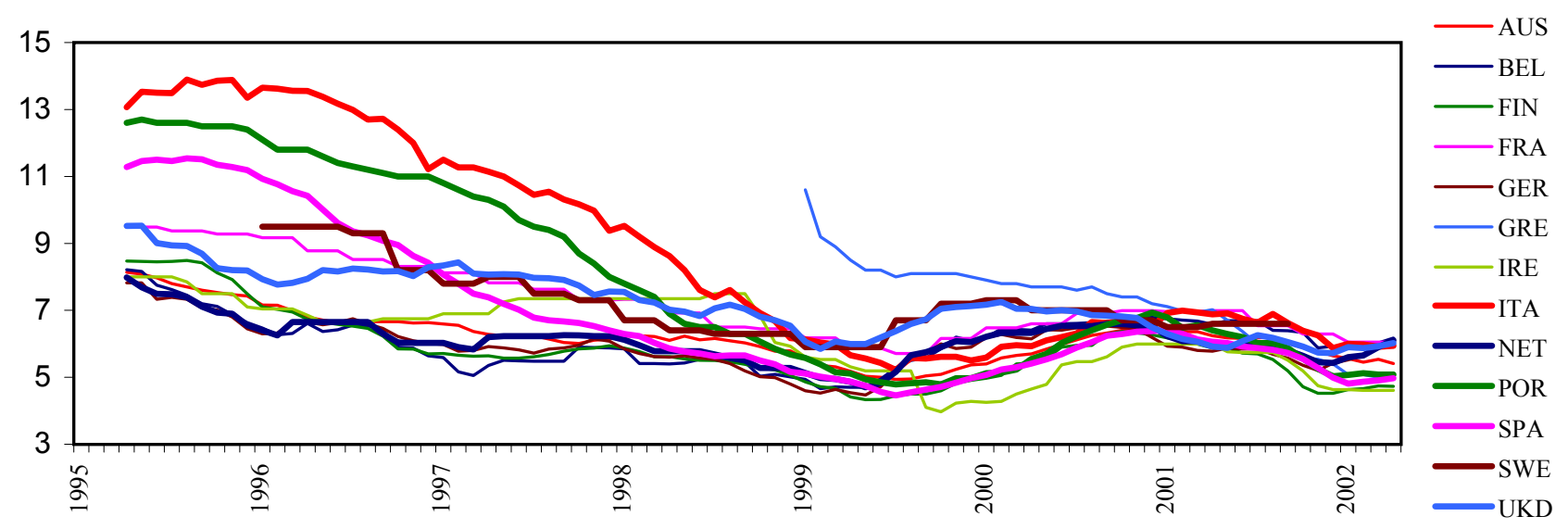

Panel B: Consumer Rates

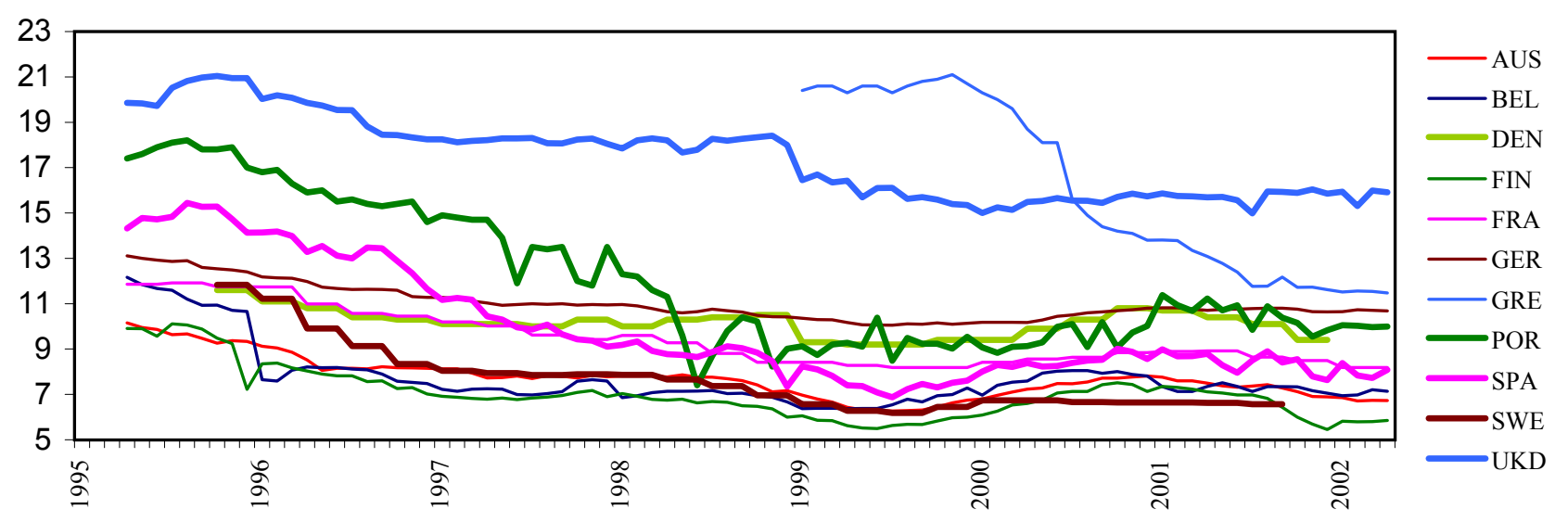

Panel C: Corporate Rates

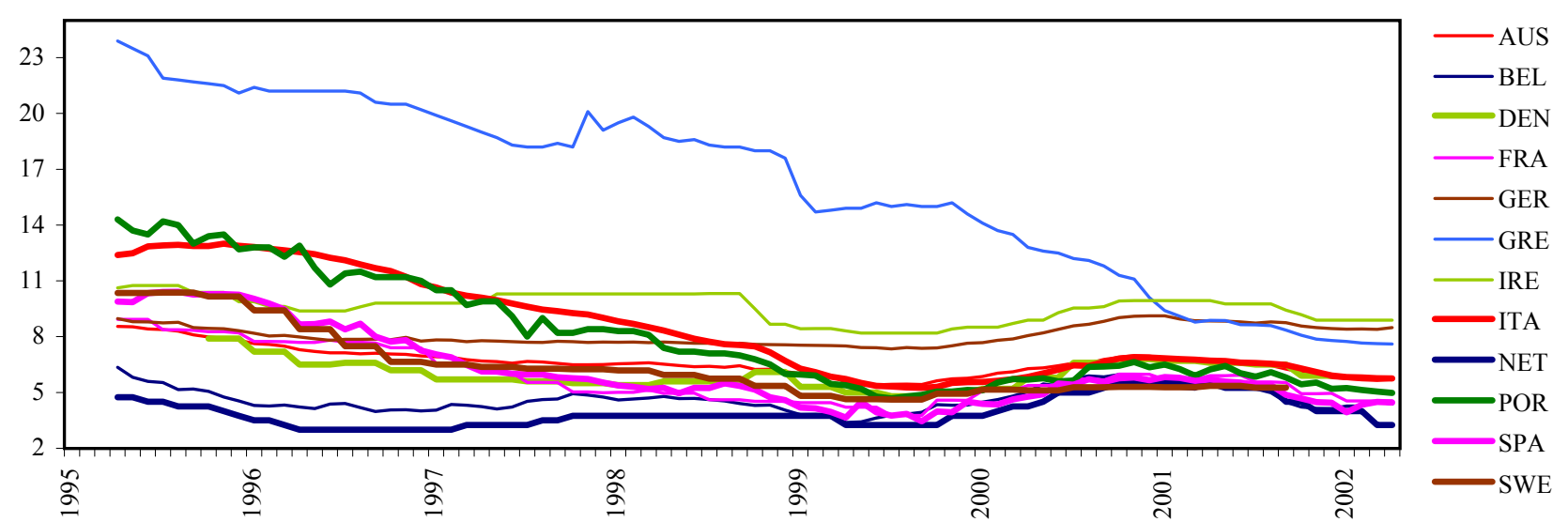


Figure 2: Real Interest Rates

Panel A: Mortgage Rates

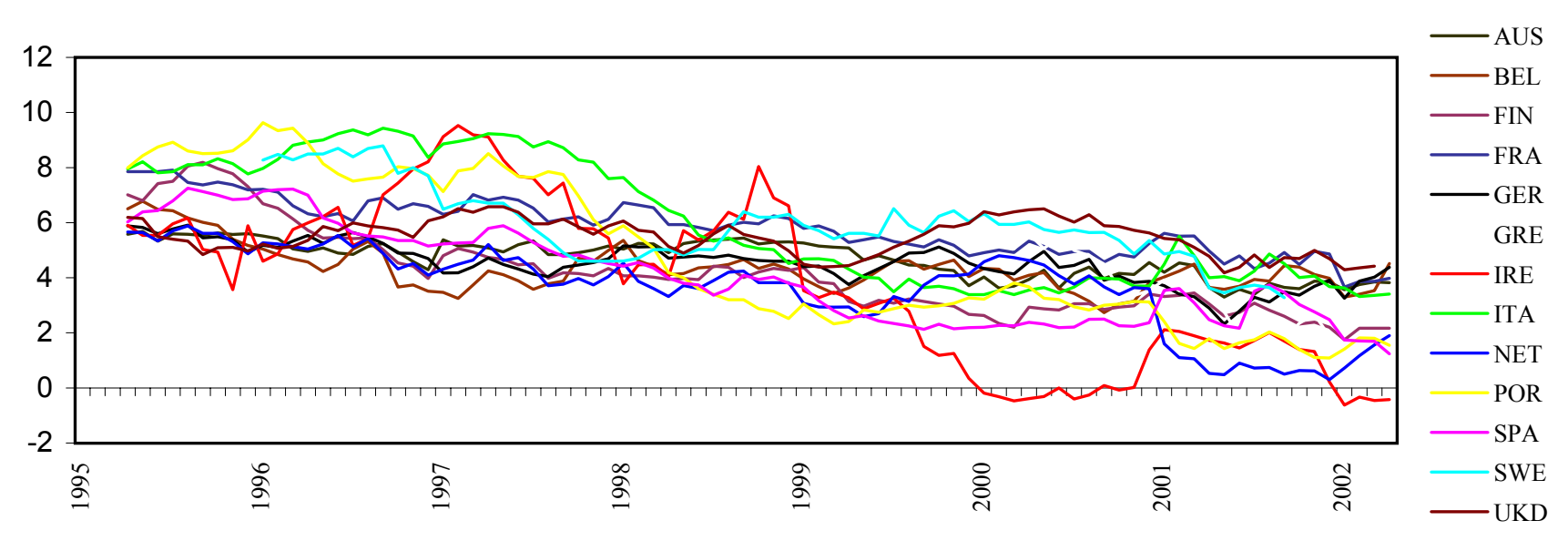

Panel B: Consumer Rates

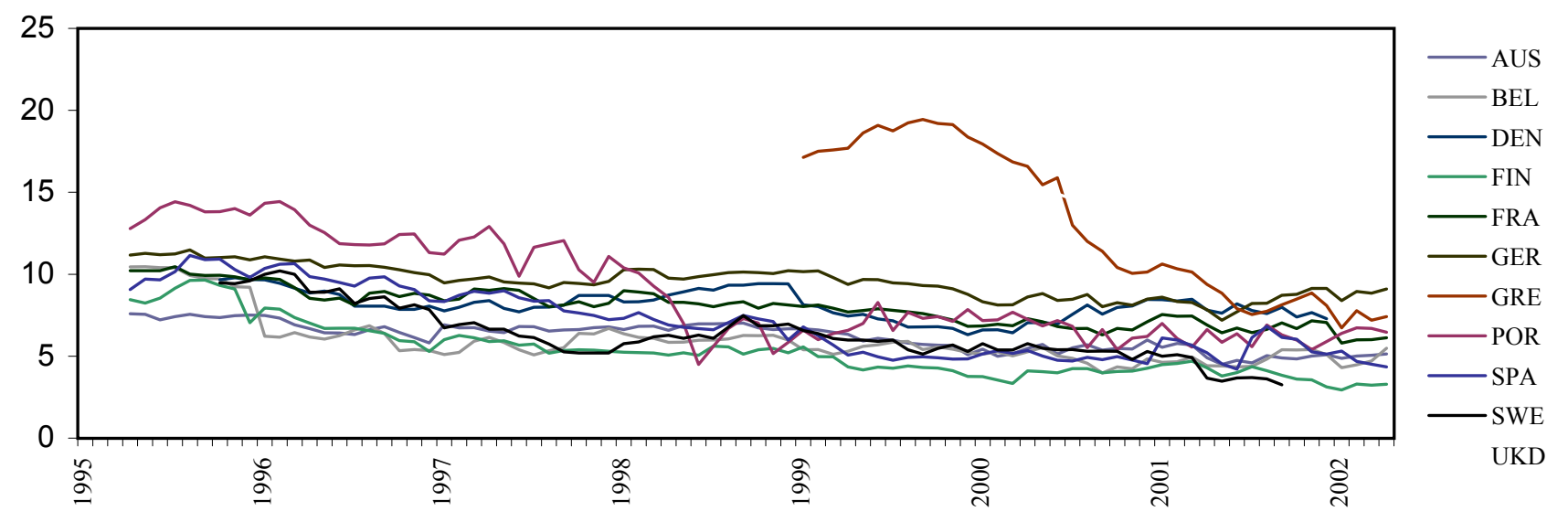

Panel C: Corporate Rates

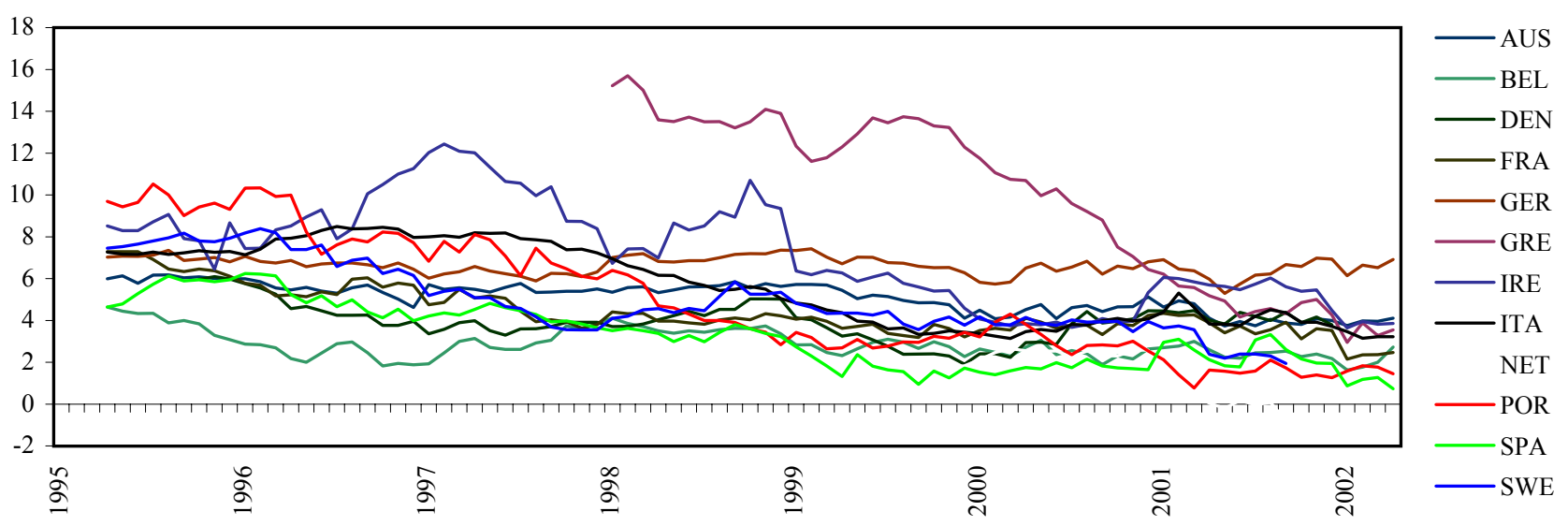


Figure 3: Interest Rate Spreads

Panel A: Mortgage Rates

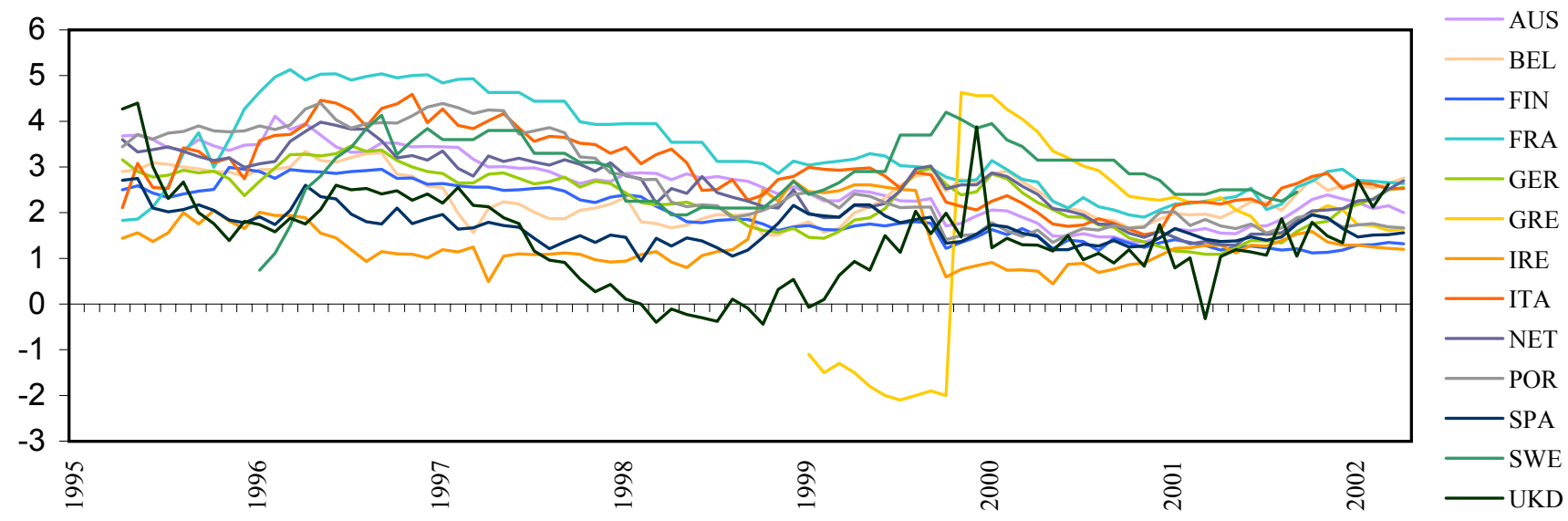

Panel B: Consumer Rates

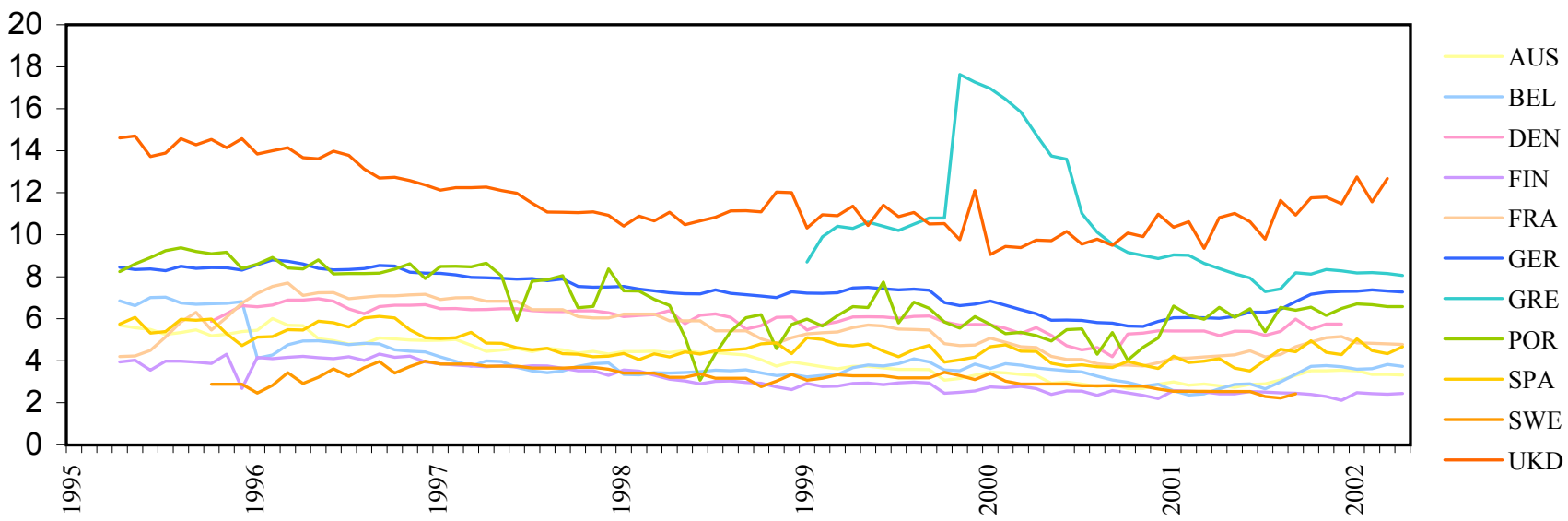

Panel C: Corporate Rates

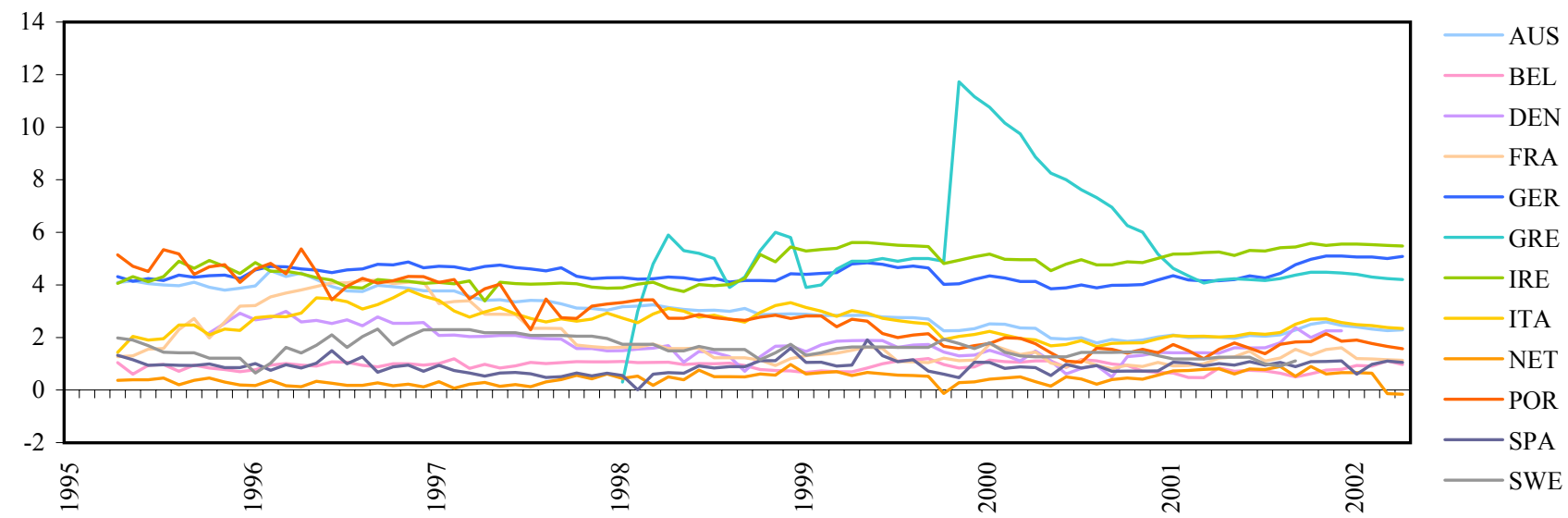




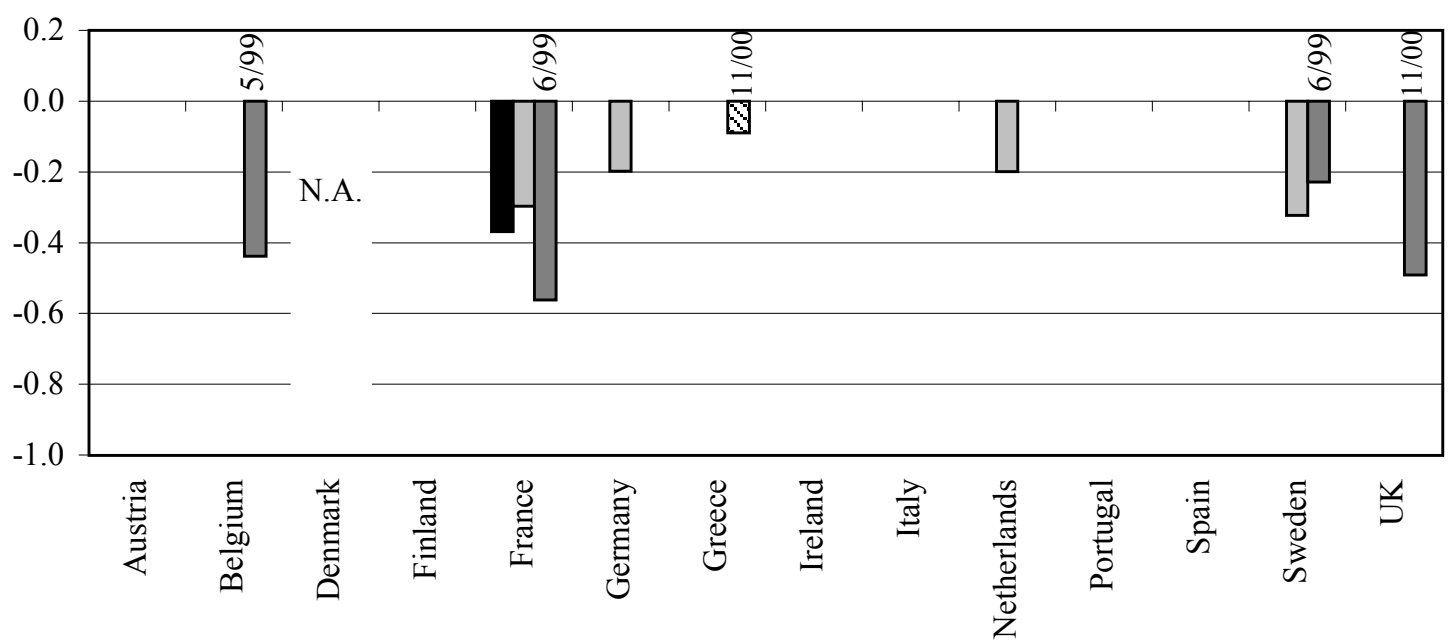

full period $\square$ pre-EMU period $\square$ EMU period

Panel B: Error Correction Terms for Nominal Consumer Lending Rates

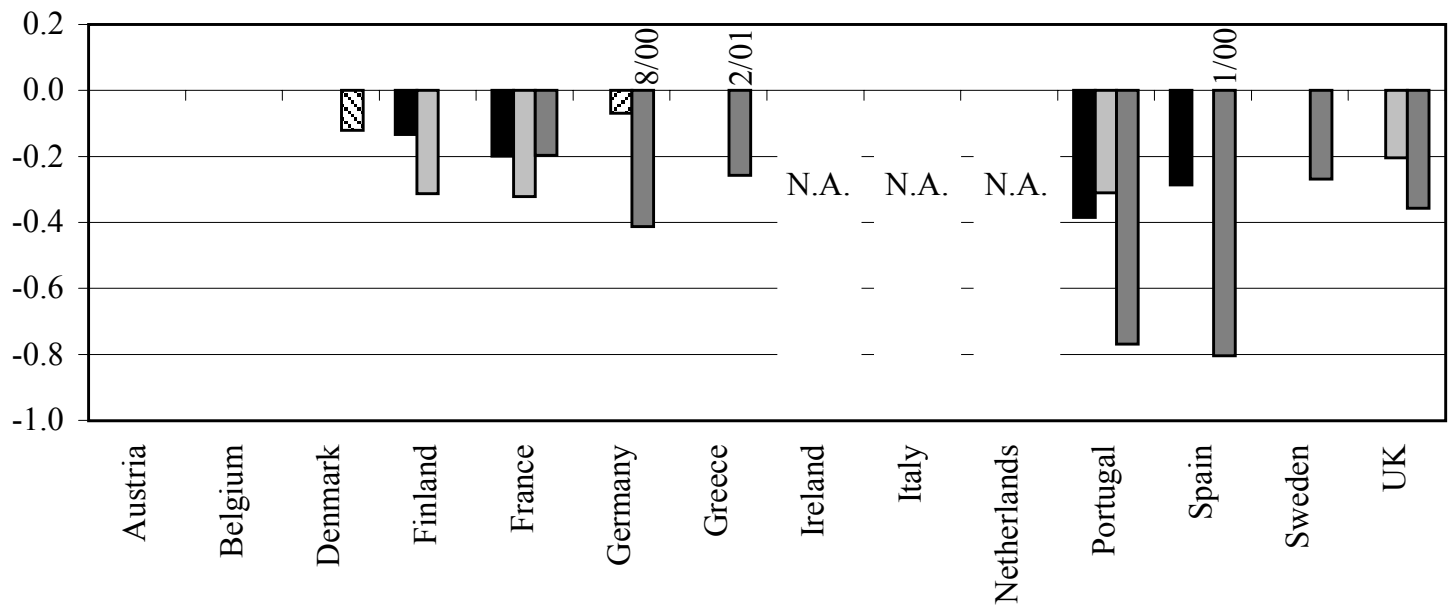

full period $\square$ pre-EMU period $\square$ EMU period

\section{Panel C: Error Correction Terms for Nominal Corporate Lending Rates}

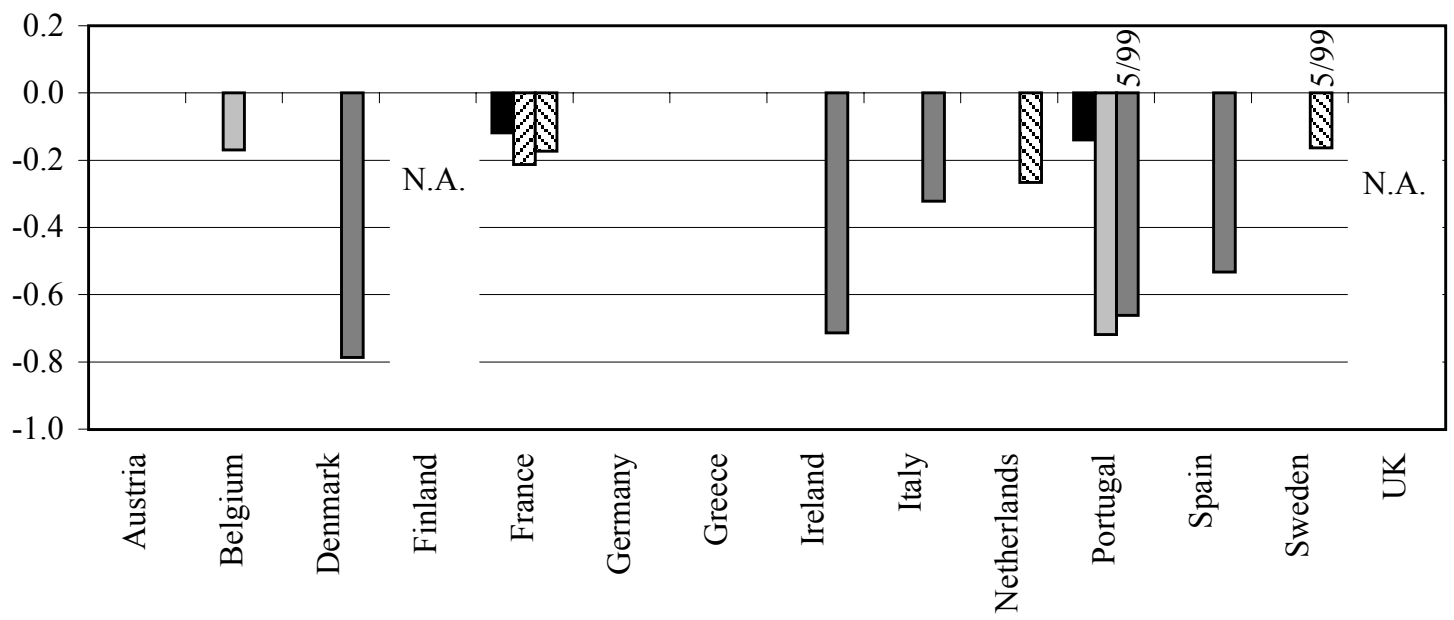

full period $\square$ pre-EMU period $\square$ EMU period

Note: ECTs are shown only when significant cointegration relationship was found. Striped bars indicate that ECT is not significantly differently from zero $(10 \%$ level) with the following patterns: horizontal for full period. diagonal bottom left to top right for pre-EMU period, and diagonal top left to bottom right for EMU period. 


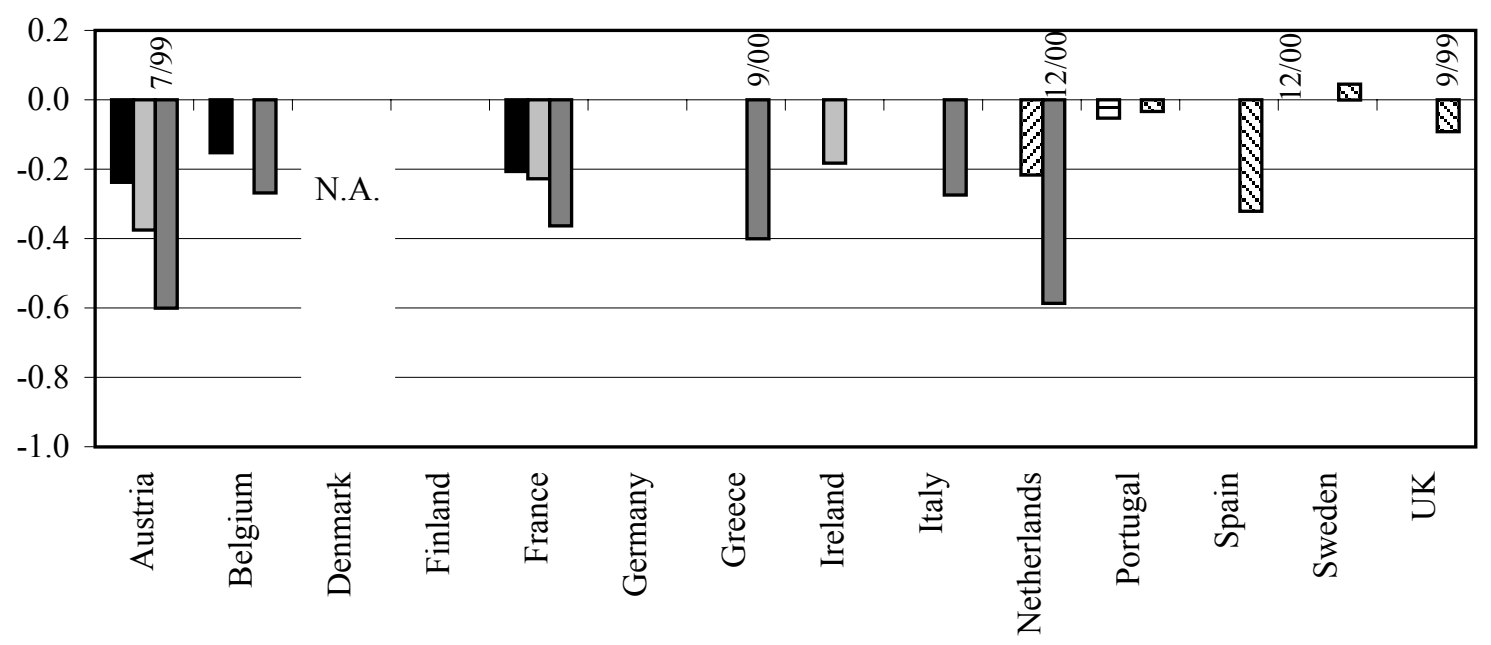

$\square$ full period $\square$ pre-EMU period $\square$ EMU period

\section{Panel B: Error Correction Terms for Real Consumer Lending Rates}

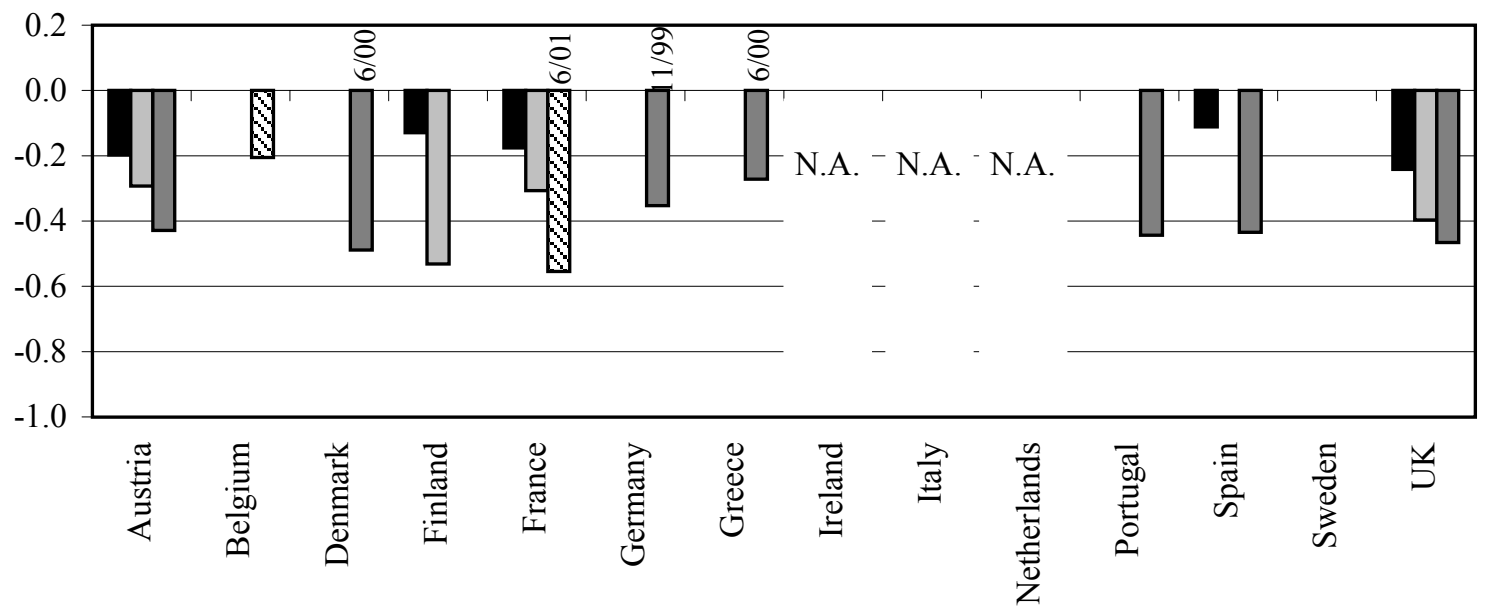

full period $\square$ pre-EMU period $\square$ EMU period

\section{Panel C: Error Correction Terms for Real Corporate Lending Rates}

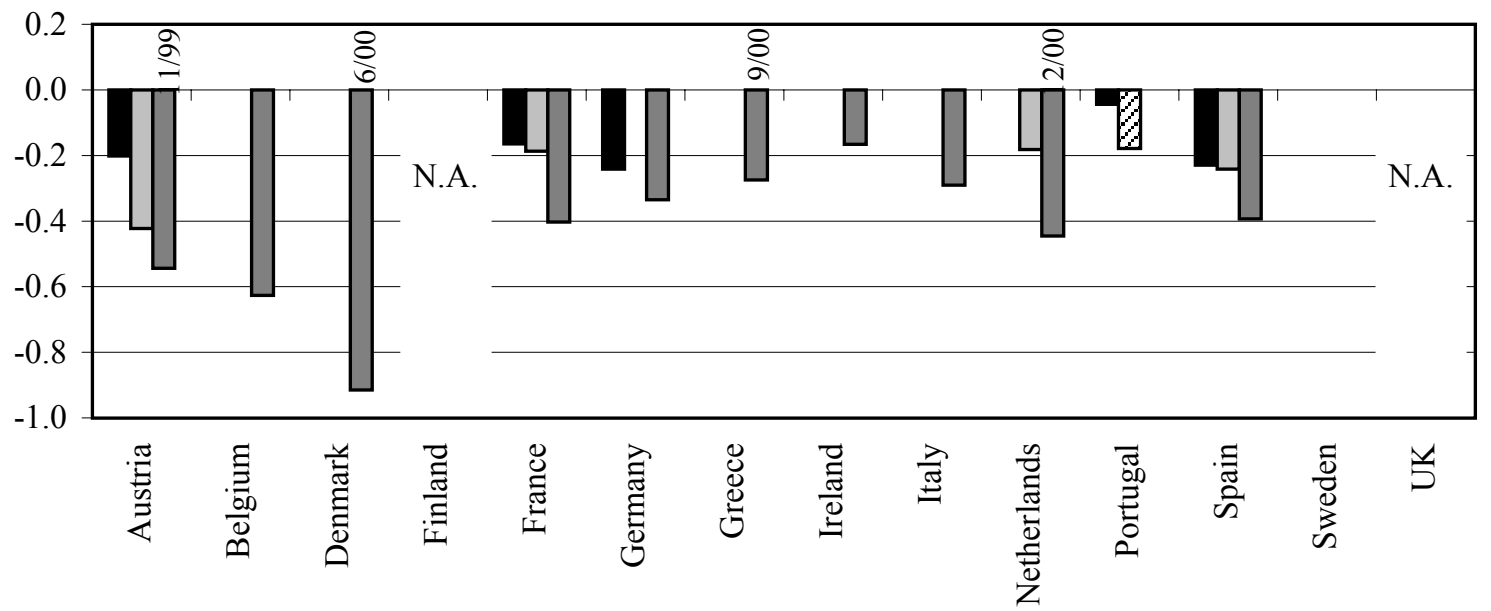

$\square$ full period $\square$ pre-EMU period $\square$ EMU period 


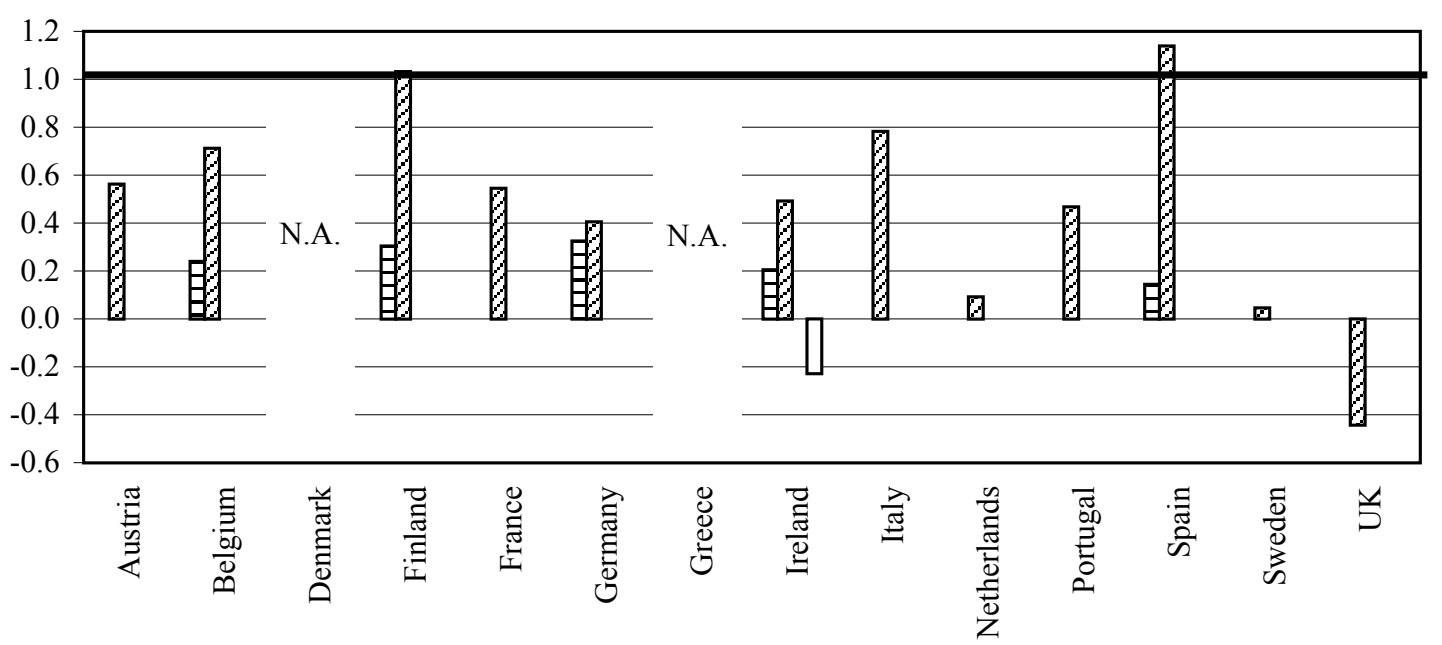

日impact multiplier $₫$ long-run multiplier $\square$ ECT1 $\square$ ECT2 $\square$ ECT3

Panel B: Consumer Lending Rates

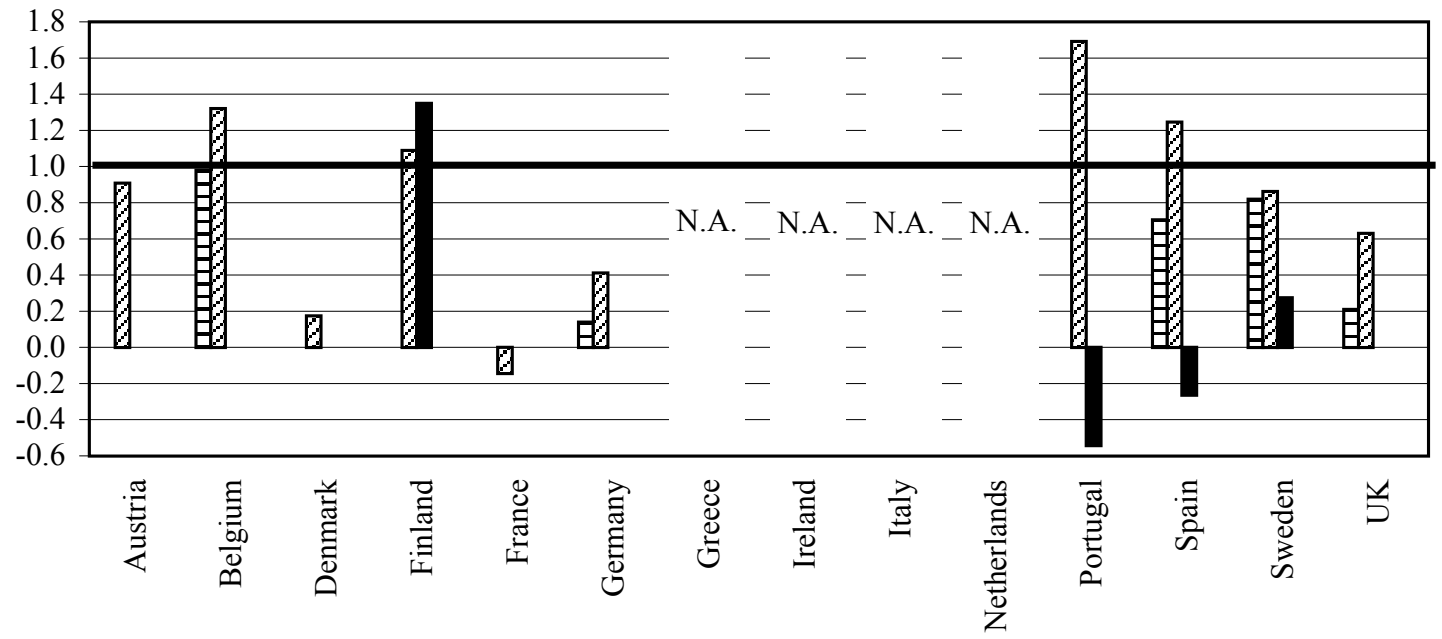

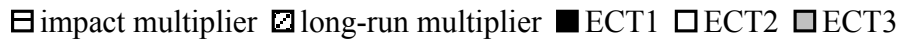

Panel C: Corporate Lending Rates

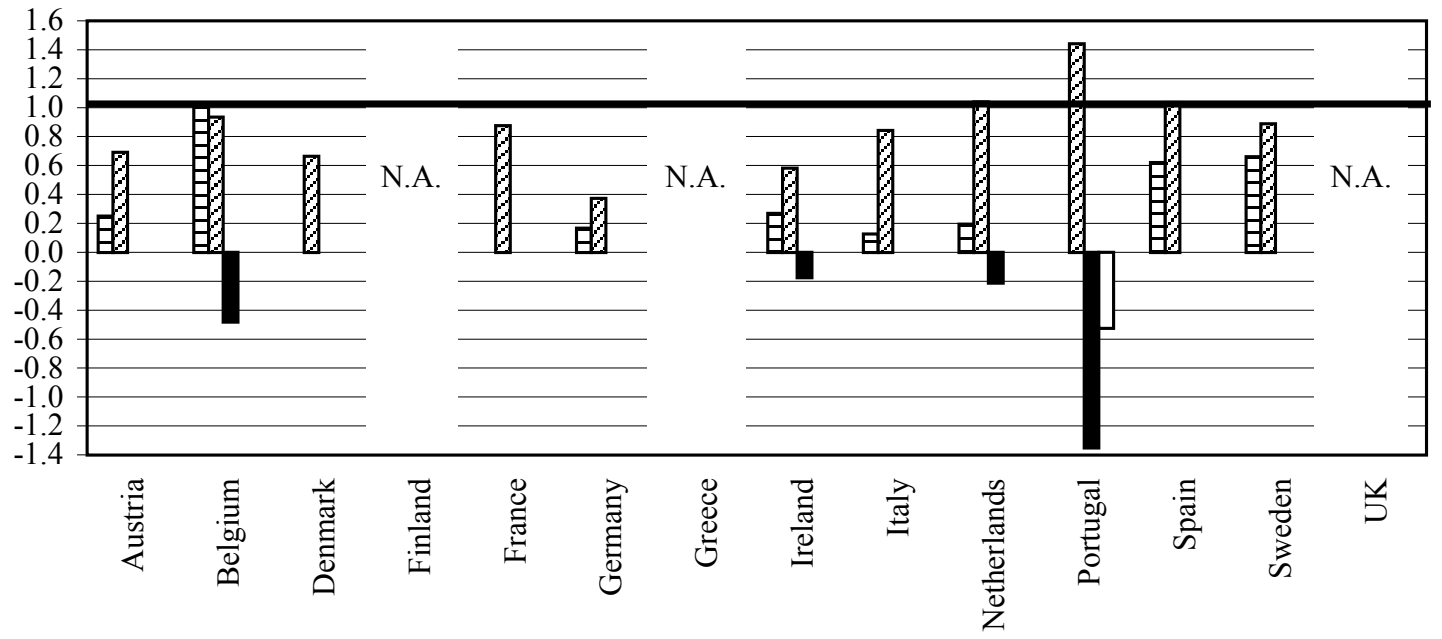

日impact multiplier $\mathbb{Q}$ long-run multiplier $\square$ ECT1 $\square$ ECT2 $\square$ ECT3 


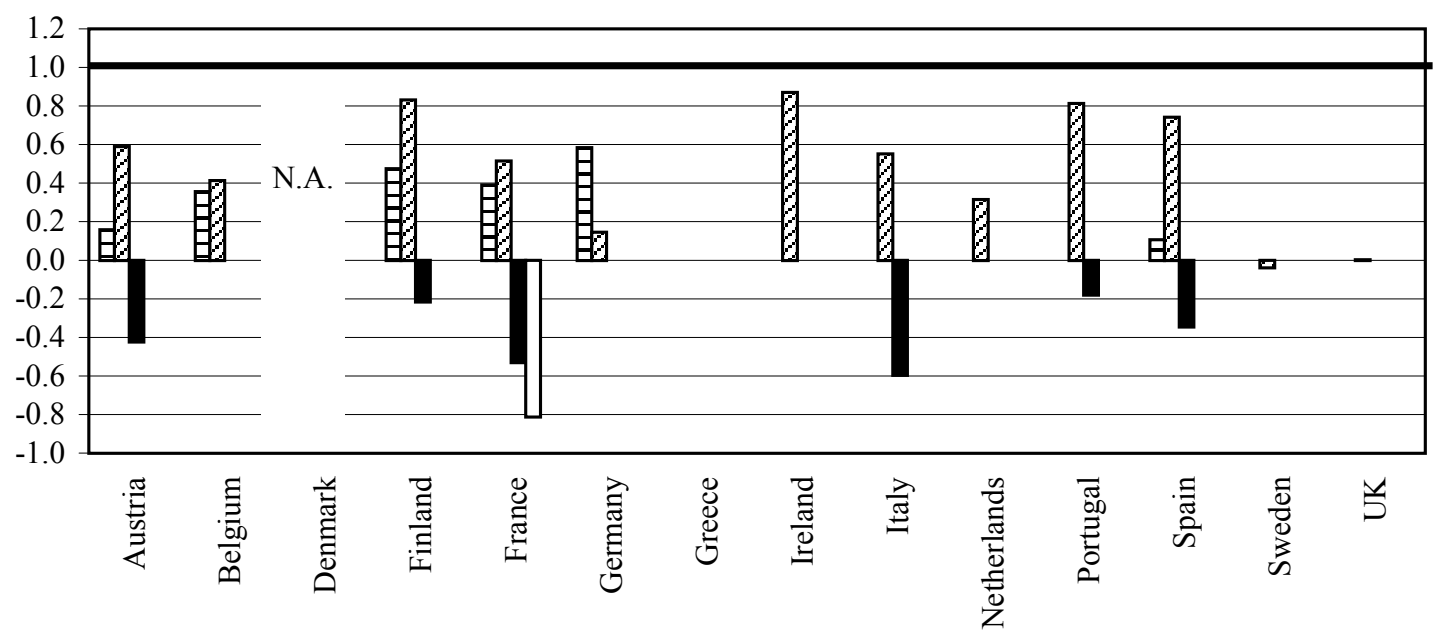

曰impact multiplier $\mathbb{0}$ long-run multiplier $\square$ ECT1 $\square$ ECT2 $\square$ ECT3

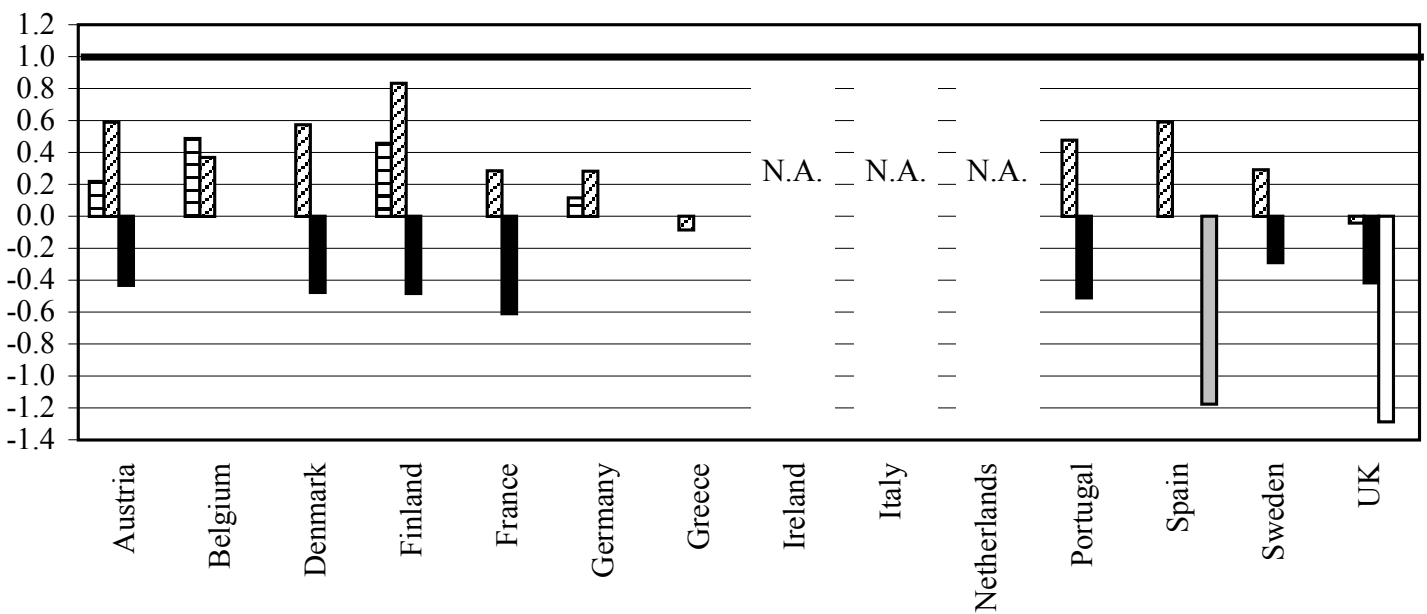

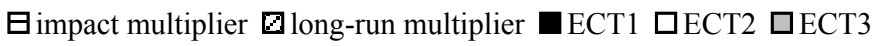

\section{Panel C: Corporate Lending Rates}

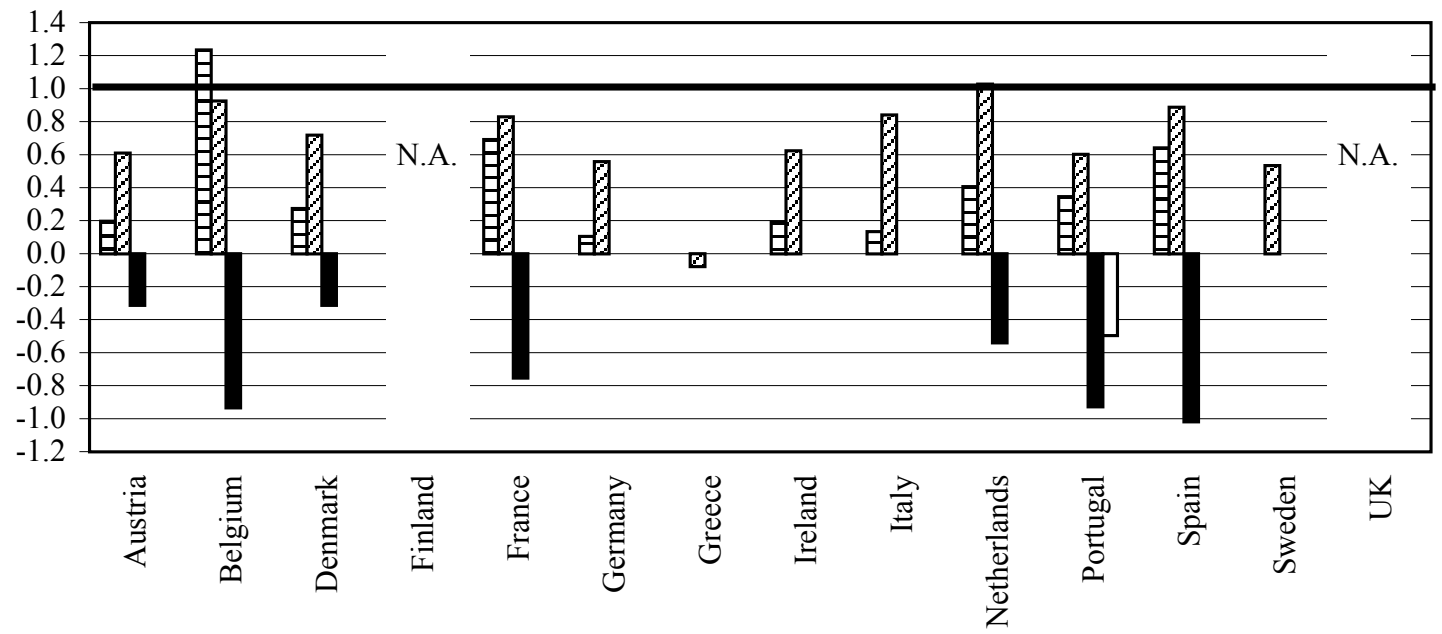

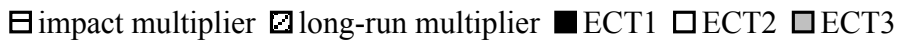


Figure A1: Rolling Chow Tests - Nominal Interest Rates

Panel A: Mortgage Lending Rates
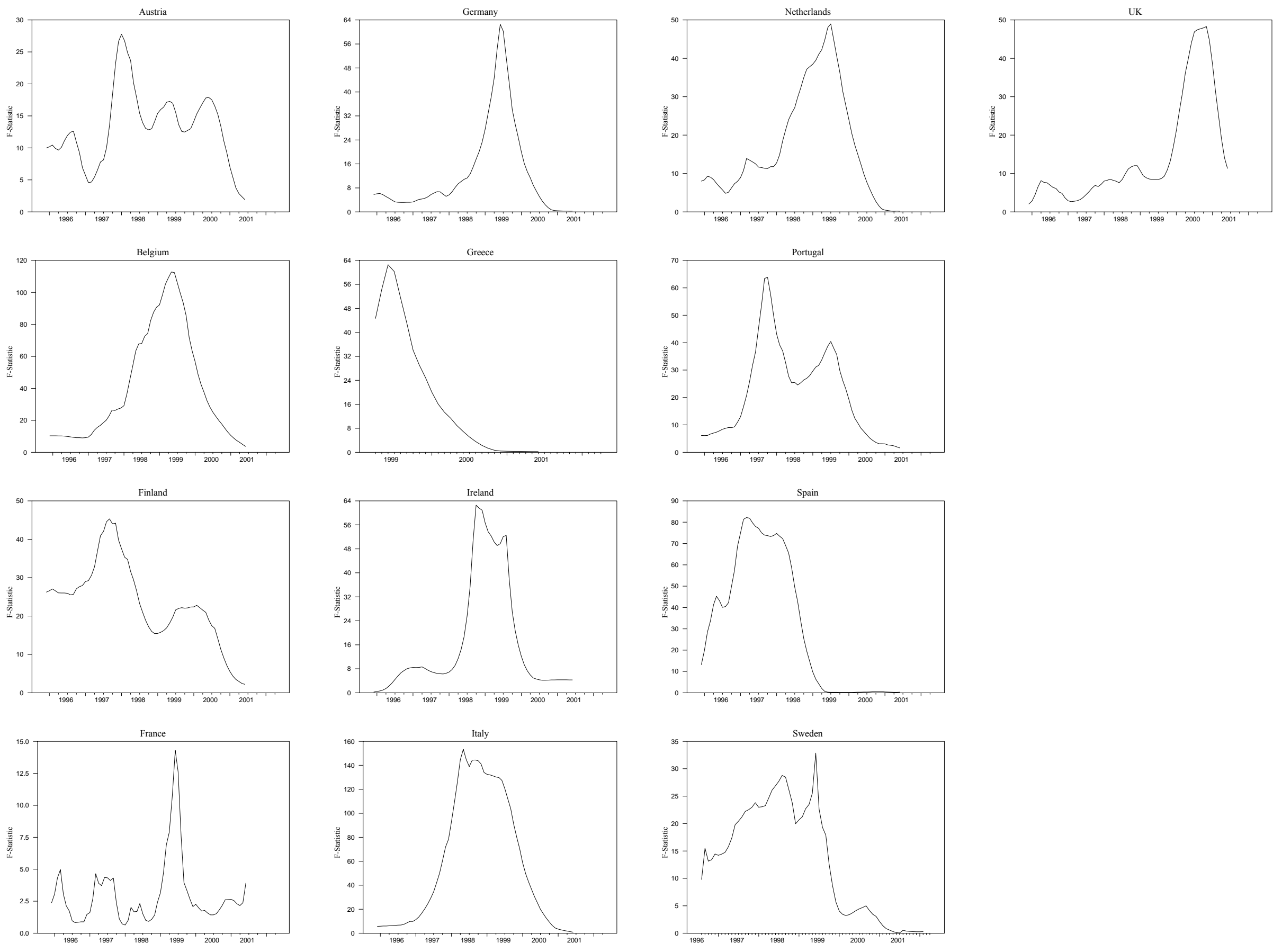


\section{Figure A1 continued}
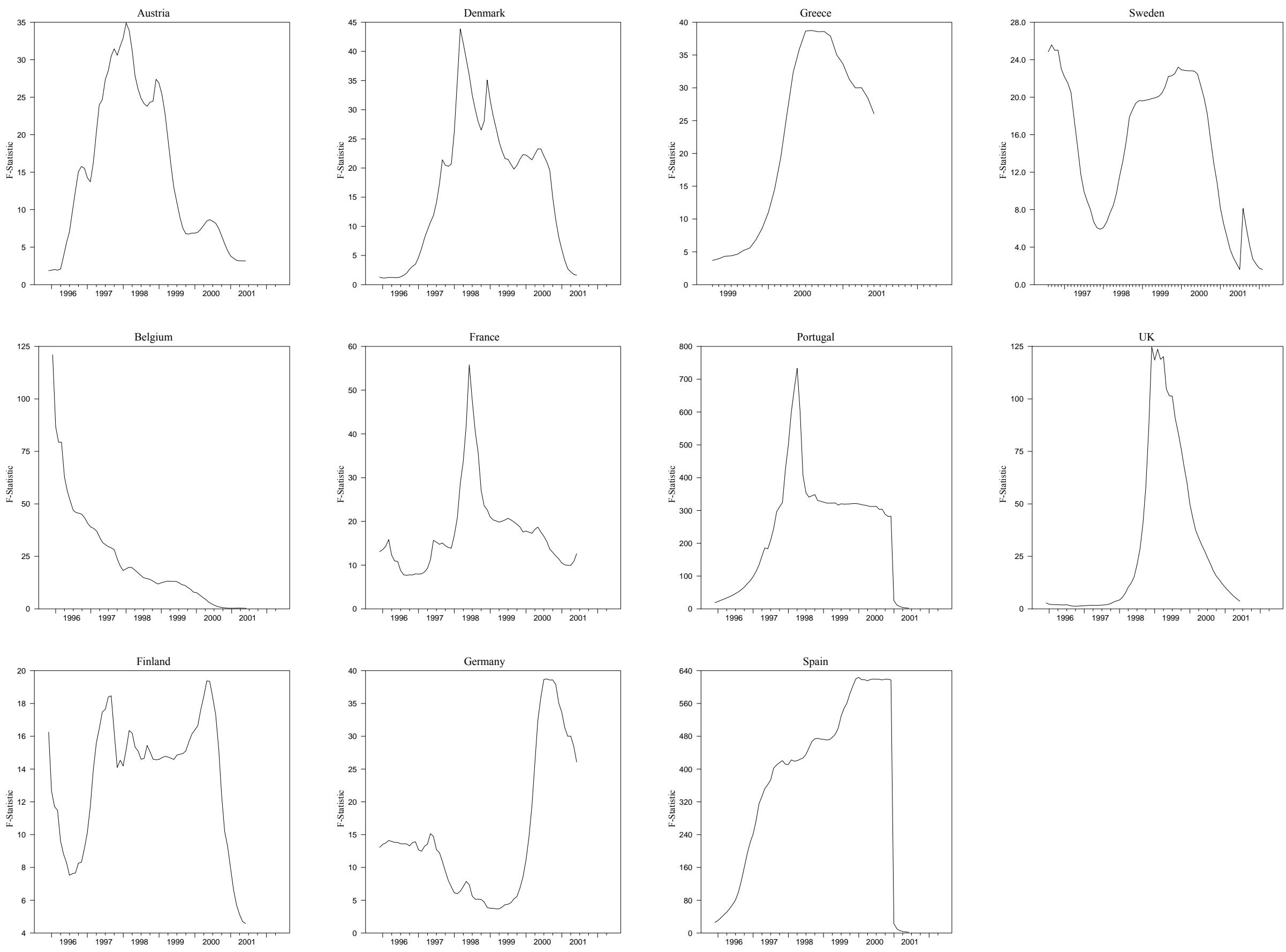


\section{Figure A1 continued}

Panel C: Corporate Lending Rates
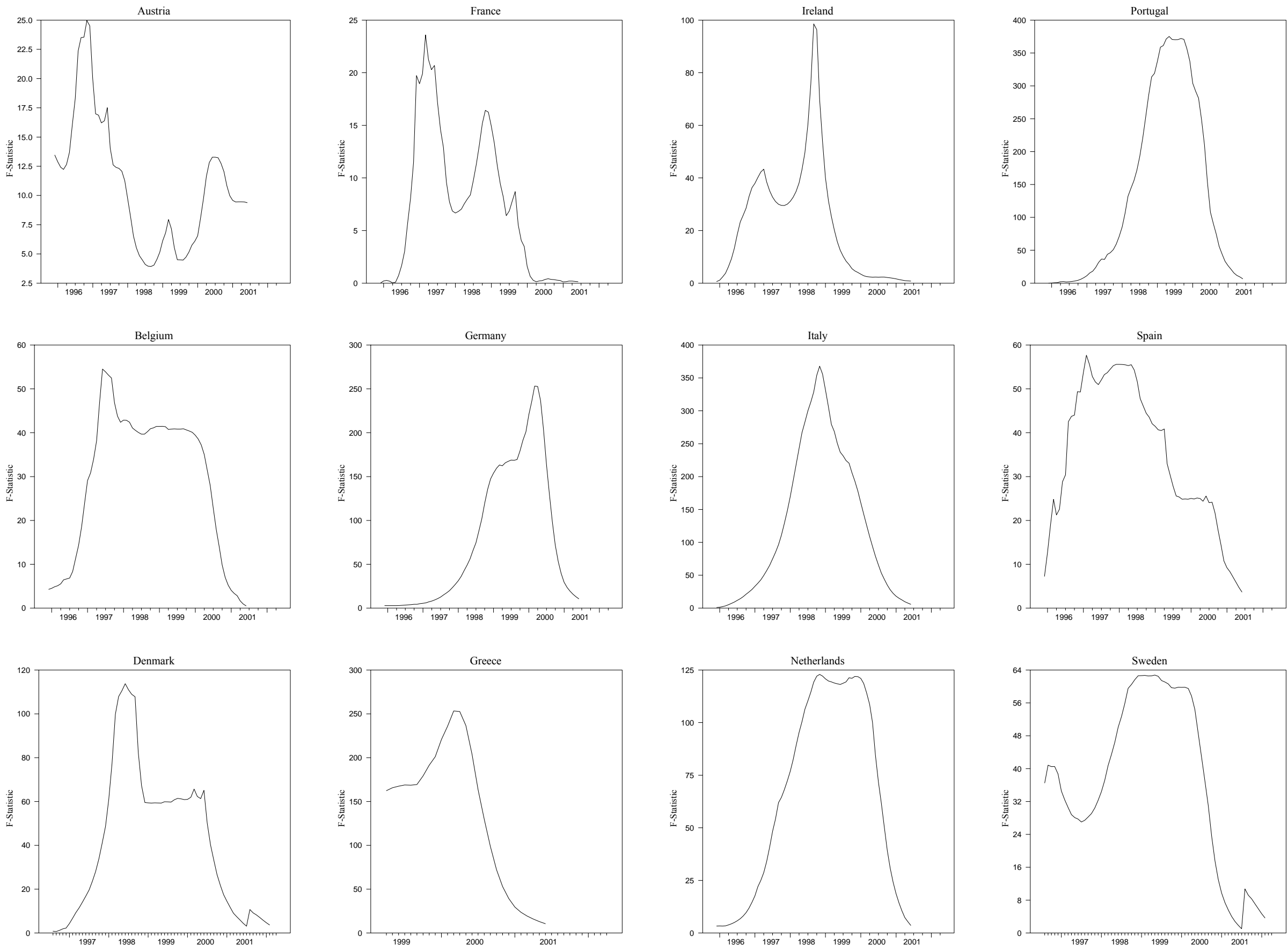
Figure A2: Rolling Chow Tests - Real Interest Rates
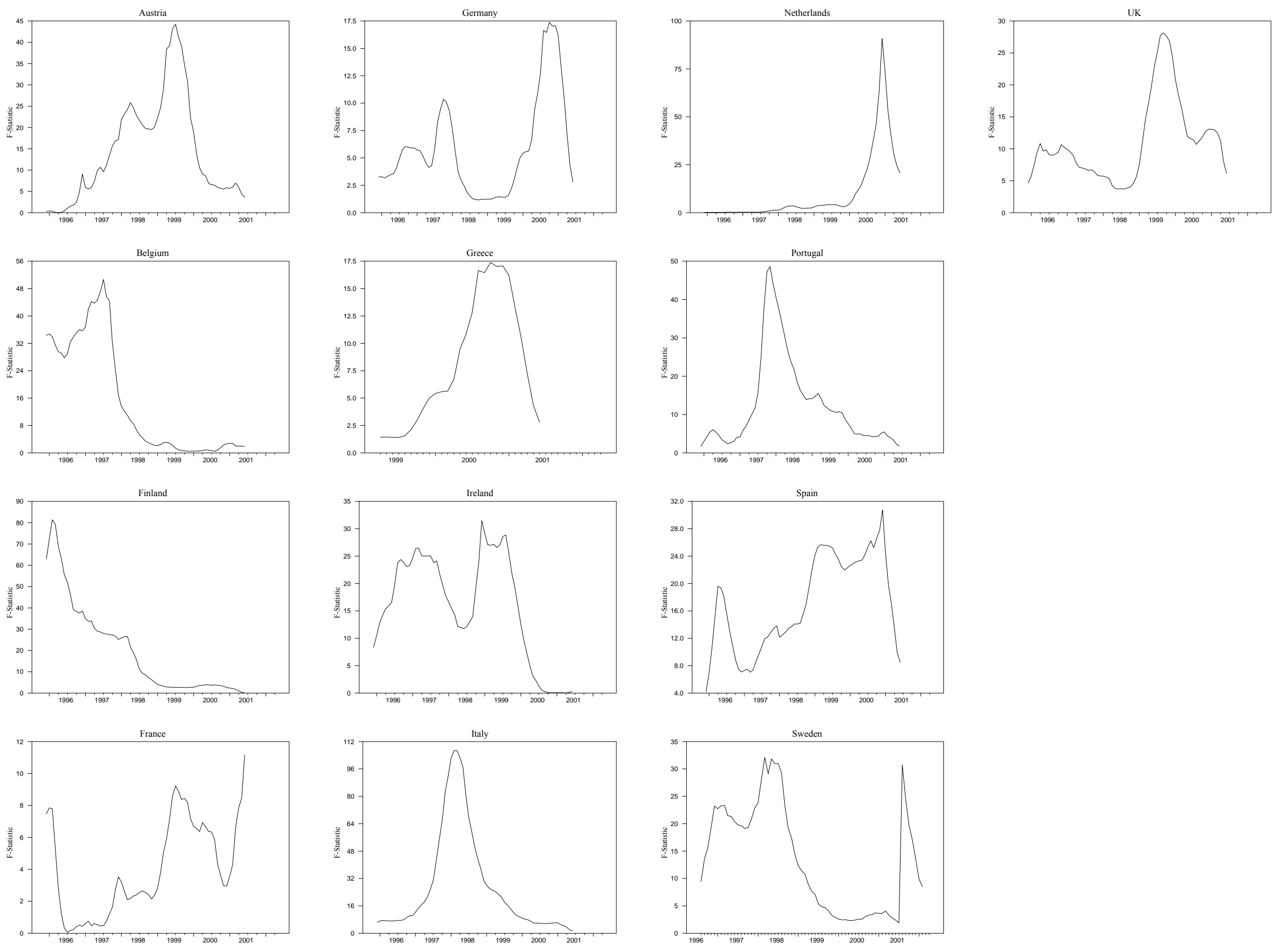


\section{Figure A2 continued}

Panel B: Consumer Lending Rates
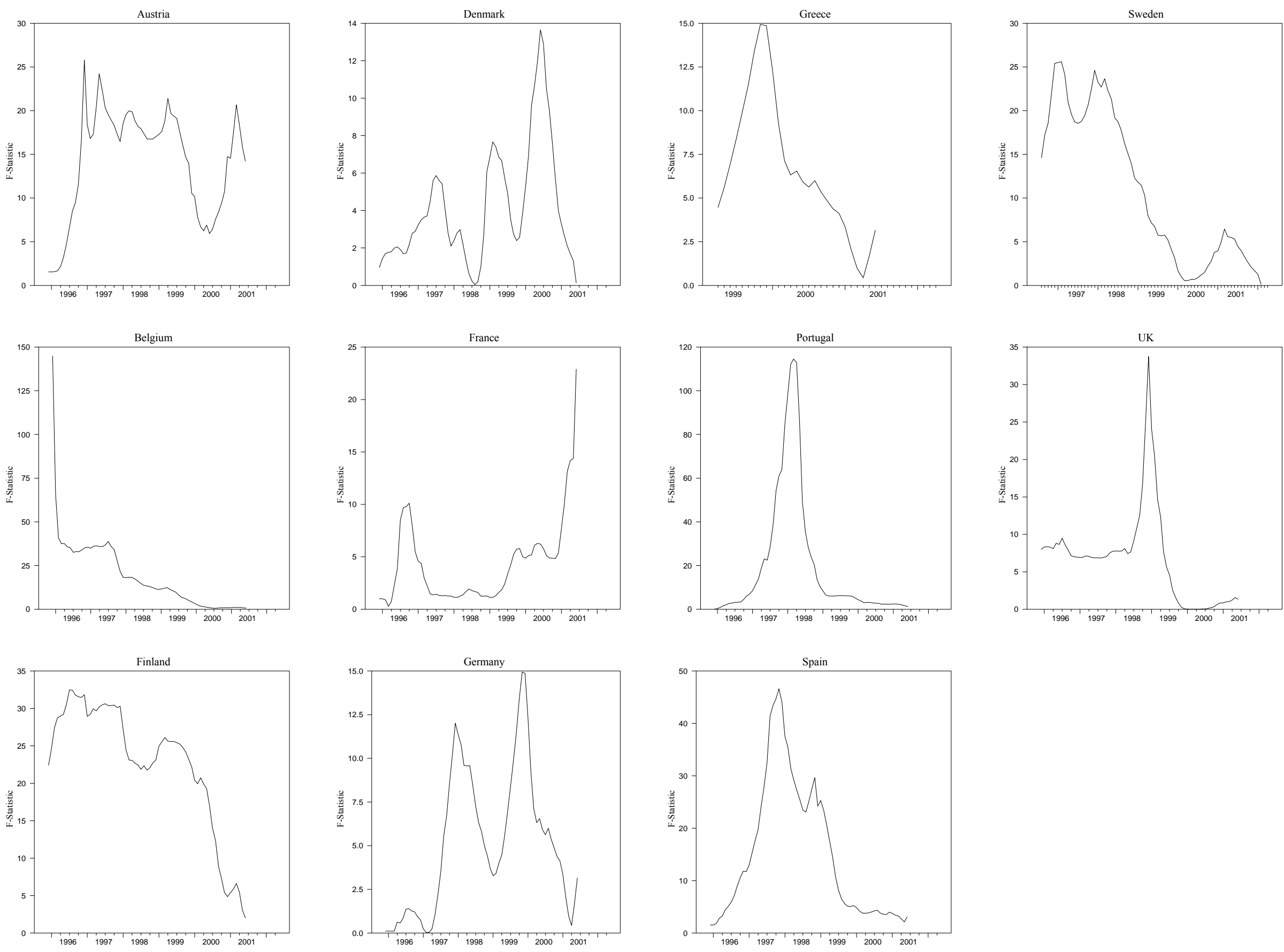


\section{Figure A2 continued}

Panel C: Corporate Lending Rates
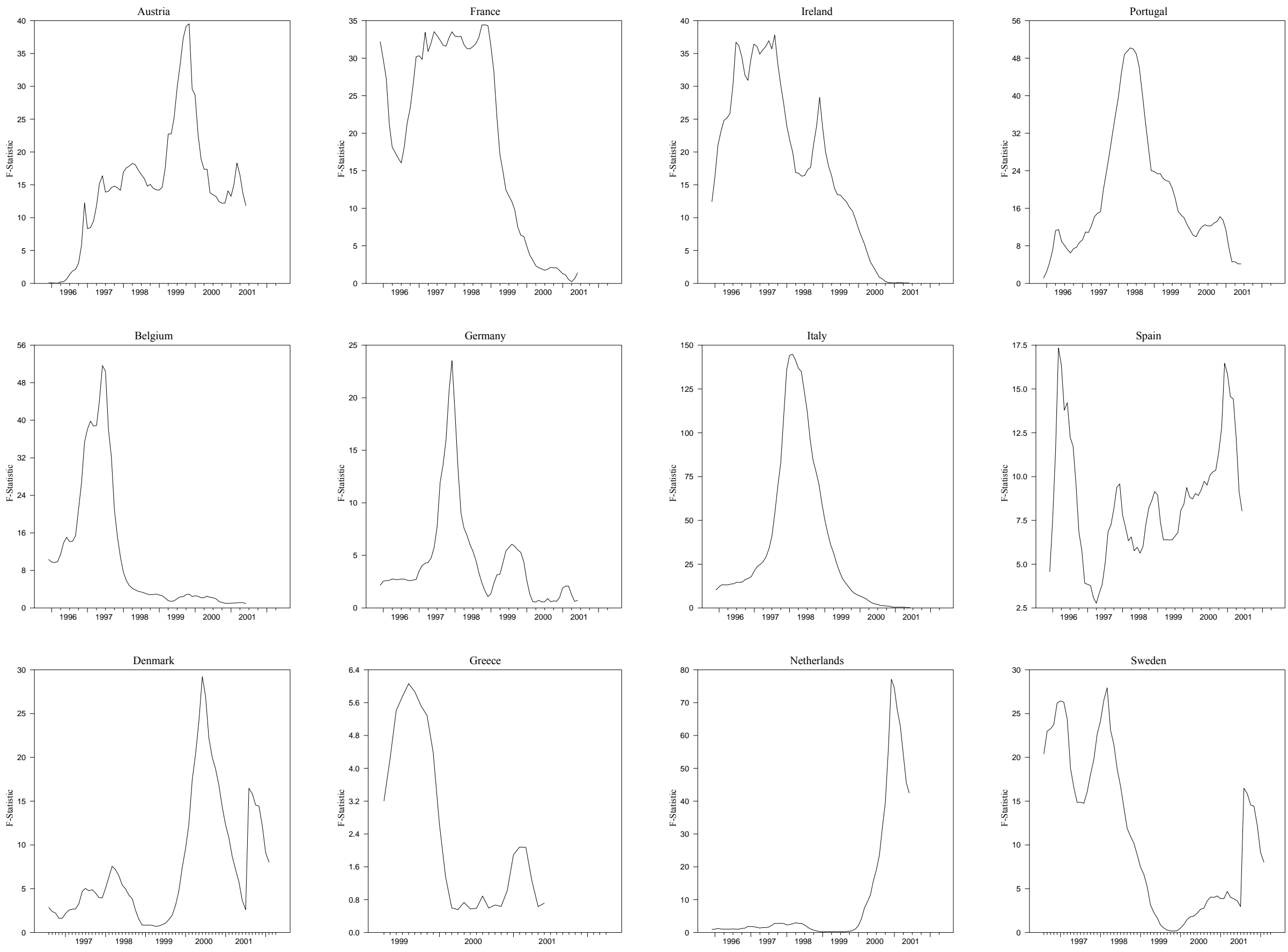